\title{
Mountain Home Air Force Base, Idaho Geothermal Resource Assessment and Future Recommendations
}

Joseph C Armstrong Robert P. Breckenridge James Kessler Thomas Lachmar Dennis L. Nielson Douglas Schmitt John W. Shervais Thomas R. Wood

March 2013

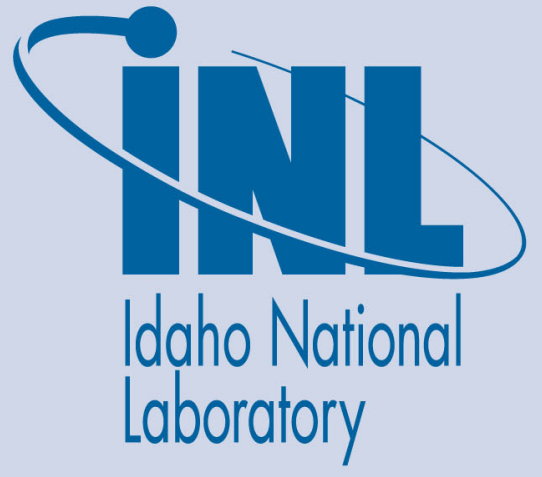

The INL is a U.S. Department of Energy National Laboratory operated by Battelle Energy Alliance 


\section{DISCLAIMER}

This information was prepared as an account of work sponsored by an agency of the U.S. government. Neither the U.S. government nor any agency thereof, nor any of their employees, makes any warranty, expressed or implied, or assumes any legal liability or responsibility for the accuracy, completeness, or usefulness, of any information, apparatus, product, or process disclosed, or represents that its use would not infringe privately owned rights. References herein to any specific commercial product, process, or service by trade name, trade mark, manufacturer, or otherwise, does not necessarily constitute or imply its endorsement, recommendation, or favoring by the U.S. government or any agency thereof. The views and opinions of authors expressed herein do not necessarily state or reflect those of the U.S. government or any agency thereof. 


\title{
Mountain Home Air Force Base, Idaho Geothermal Resource Assessment and Future Recommendations
}

\author{
Joseph C. Armstrong ${ }^{1}$ \\ Robert P. Breckenridge ${ }^{2}$ \\ James Kessler ${ }^{3}$ \\ Thomas Lachmar ${ }^{3}$ \\ Dennis L. Nielson ${ }^{4}$ \\ Douglas Schmitt ${ }^{5}$ \\ John W. Shervais ${ }^{3}$ \\ Thomas R. Wood ${ }^{2}$ \\ ${ }^{1}$ U.S. Air Force, Mountain Home Air Force Base, Idaho \\ ${ }^{2}$ Energy \& Environmental Sciences \& Technology, Idaho National Laboratory, \\ Idaho Falls, Idaho \\ ${ }^{3}$ Department of Geology, Utah State University, Logan, Utah \\ ${ }^{4}$ Drilling, Observation, and Sampling of the Earths Continental Crust (DOSECC), Inc., \\ Salt Lake City, Utah \\ ${ }^{5}$ Department of Physics, University of Alberta, Edmonton, AB, T6G 2E1
}

March 2013

Idaho National Laboratory

Idaho Falls, Idaho 83415

http://www.inl.gov

Prepared for the

U.S. Department of Energy

Assistant Secretary for Energy Efficiency and Renewable Energy

Under DOE Idaho Operations Office

Contract DE-AC07-05ID14517 
INTENTIONALLY BLANK 


\section{EXECUTIVE SUMMARY}

The U.S. Air Force is facing a number of challenges as it moves into the future, one of the biggest being how to provide safe, secure, green energy to support base operations. To support addressing this energy challenge a team of scientists and engineers met at Mountain Home Air Force Base (MHAHB), Idaho in early 2011 to discuss the possibility of exploring for geothermal resources under the base. On the basis of existing regional and local data the team determined there was a reasonable potential for a geothermal resource to exist beneath the base large enough to supply a large portion of the MHAFB power. A regional gravity map helped identify several possible locations for drilling a new well to confirm or deny the existence of a viable geothermal resource. The team located several possible sources of funding for this well - the best being to partner with U.S. Department of Energy (DOE) funded "Project Hotspot". This approach would leverage over a million dollars of DOE funds with $\sim \$ 700 \mathrm{~K}$ of Air Force funds to drill a 6,000 ft deep geothermal test well. To provide a clear separation between funding sources, Project Hotspot funds were used to core drill through the thick layer of lakebed sediments in the upper half of the well. The Project Hotspot effort satisfied many scientific questions posed by DOE research regarding the depositional and tectonic history of the region. U.S. Air Force funds were used to drill the bottom half of the well to understand the depth, temperature and extent of the geothermal resource.

The well was designed as a slimhole well and permitted in accordance with State of Idaho Department of Water Resources rules and regulations. Drilling operations commenced at the Mountain Home site in July of 2011 and were completed in January of 2012. Temperatures increased gradually, especially below a depth of $2000 \mathrm{ft}$. Temperatures increased more rapidly below a depth of $5500 \mathrm{ft}$. The bottom of the well is at $5976 \mathrm{ft}$, where a temperature of about $140^{\circ} \mathrm{C}$ was recorded. The well flowed artesian from a depth of $5600 \mathrm{ft}$. Water samples were collected for detailed geochemical analyses. Water flowed at land surface until it was plugged off with a heavy drilling mud so that core drilling could continue. Thousands of feet of core samples were collected from the well and are being analyzed to help understand the geothermal reservoir, the permeability at depth and other factors related to the evolution of a continental hotspot (Yellowstone Caldera).

Numerous cutting-edge geophysical techniques were employed to characterize the physical and hydrological properties of the geologic formations. A downhole televiewer survey was conducted to evaluate the orientation and directions of fractures at depth. Analyses of the new data collected from MH-2, leads to the interpretation that the Mountain Home Geothermal System derives its enthalpy from a layered basaltic sill complex in the middle to upper crust. Unlike basalt-driven systems in Iceland and Hawaii, which are associated with relatively short-lived basaltic dikes that cool quickly, the SRP basaltic sill complex is long-lived because (a) each individual sill is $\sim 100-200 \mathrm{~m}$ thick, and (b) the intrusion of multiple sills into the same level of crust pre-heats the crust, minimizing heat loss from subsequent intrusions. If this conceptual model is correct, then geothermal resource exploration in the Western Snake River Plain should focus on locations which are far from the range front faults, and that are also located over the steep gravity gradients that mark the margins of the gravity high/horst block. The dominant exploration tool will likely be high-resolution gravity mapping, coupled with resource confirmation by a program of slim hole drilling and coring. 
An economic analysis was performed to assess the power generation costs from a resource that was postulated based on the MH-2. This analysis was performed using the US DOE's Geothermal Electricity Technology Evaluation Model, or GETEM. The model estimates capital and operating costs based on the input provided to define a specific scenario. A preliminary evaluation of the potential generation cost at Mountain Home suggests that this cost would be between 11 and 13 cents per kW-hr, provided the assumptions made were realized. Because the model produces generic estimates for costs of power and the considerable uncertainty in the costs associated with finding and developing a commercial resource, it is probable that the actual costs could be 2 to 4 cents higher or lower than this estimate. Also this estimate does not include the effect of any federal or state incentives for renewable power production, which would lower the generation cost. In conclusion, the data presented in this report show that a viable electric-grade geothermal resource prospect exists beneath Mountain Home Air Force Base (within a band of uncertainty). The economic analysis shows that the projected cost of electricity derived from this resource is comparable to other geothermal developments.

Several recommendations are made and summarized below:

1. The USAF could develop the MHAFB geothermal resource in partnership with a private geothermal developer.

2. The USAF could partner with a commercial geothermal developer to drill additional exploratory slim holes to further characterize the geothermal resource beneath the base.

3. To make the Mountain Home Geothermal Prospect more attractive to a commercial partner, the uncertainty regarding the geothermal reservoir could be reduced by the USAF partnering with a research team interested in answering scientific questions regarding the SRP geology and hydrogeology. Cost savings for expensive study of this resource could be achieved through research collaboration, similar to the approach taken in the MH-2 effort with the DOE funded Project Hotspot. This would leverage research dollars and provide the Air Force access to advanced research capabilities from academics and the Idaho National Laboratory at discounted prices. In order for this effort to be successful, it is recommended that the Air Force continue to fund a low level, but sustained, effort to keep the academic partners engaged and actively seeking external funding. 


\section{CONTENTS}

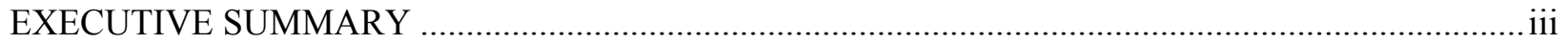

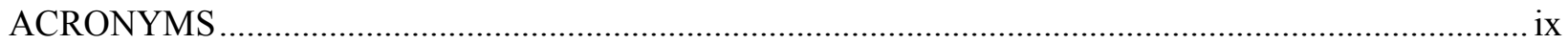

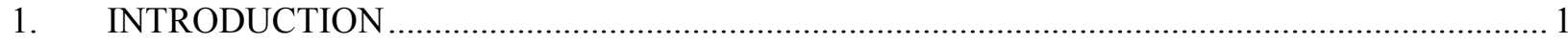

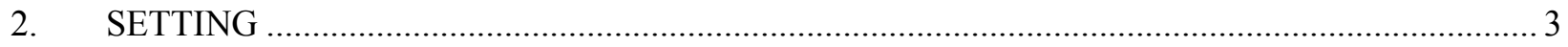

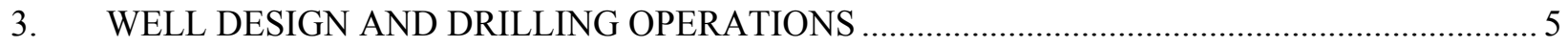

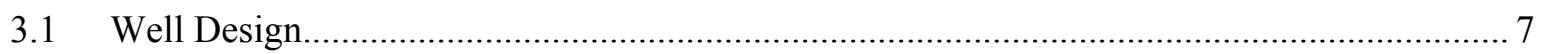

3.2 Drilling of Mountain Home Well \#2a and \#2b ................................................................. 9

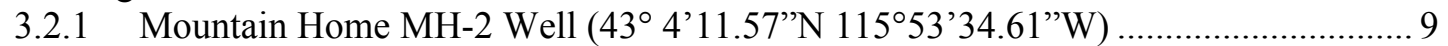

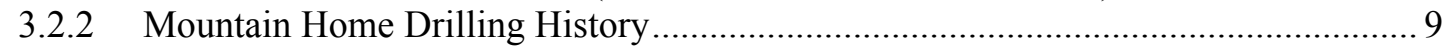

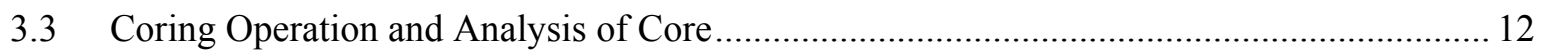

3.4 Final Plug and Abandonment of Well \#2a and \#2b ........................................................ 12

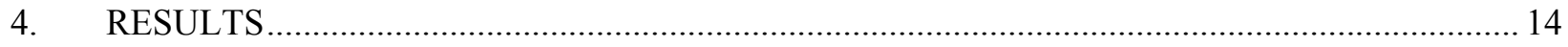

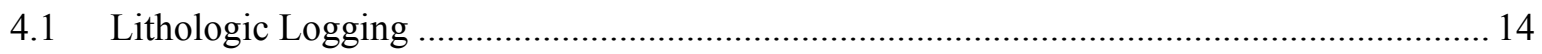

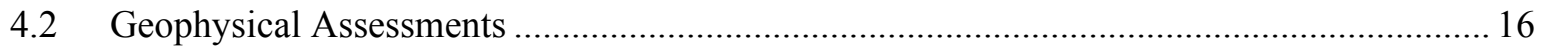

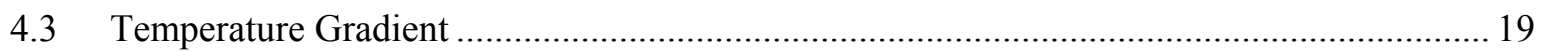

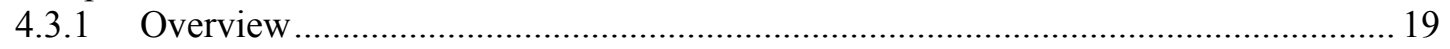

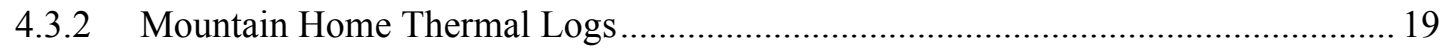

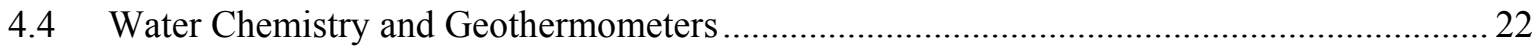

4.5 Comparison of MH Geothermal System to Raft River Site .............................................. 24

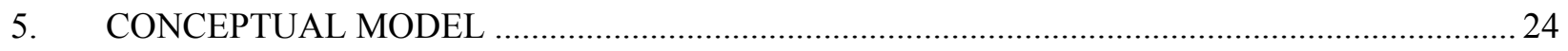

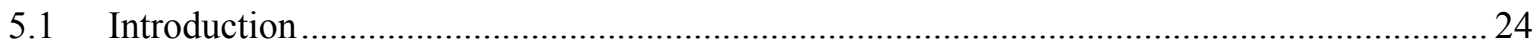

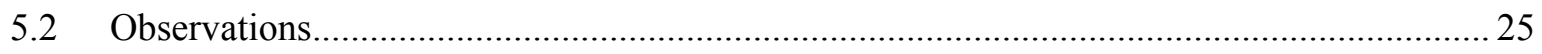

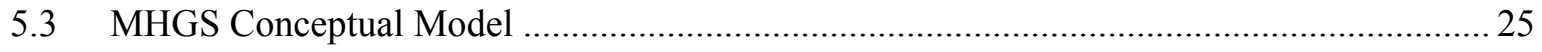

5.4 Implications for Exploration Strategies in Southern Idaho .............................................. 26

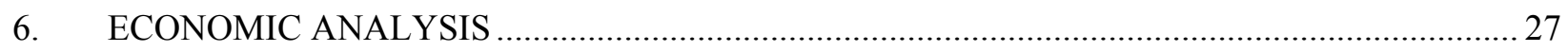

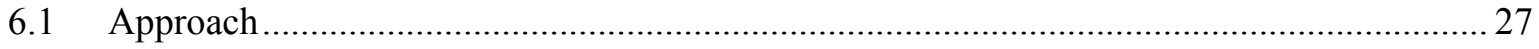

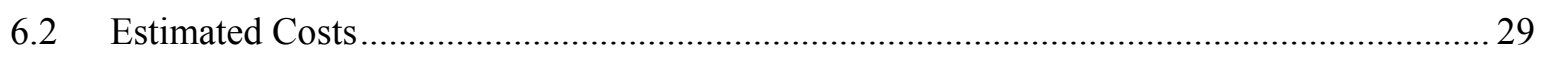

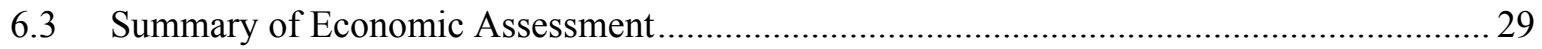

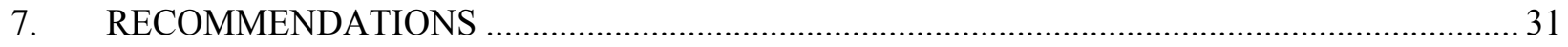

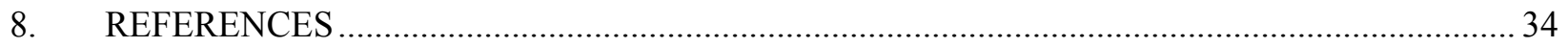




\section{FIGURES}

Figure 1.0-1. Regional Bouguer gravity anomaly near Mountain Home Air Force Base, Idaho, using existing State gravity database. Warm colors are gravity highs, cool colors are gravity lows.....

Figure 1.0-2. Regional Bouguer gravity anomaly near Mountain Home Air Force Base, Idaho, based on new high-resolution gravity (Glen, USGS). Warm colors are gravity highs, cool colors are gravity lows. 2

Figure 2.0-1. Map showing the location of Mountain Home AFB, Idaho, as well as the 1986 geothermal exploration well MH-1, the new geothermal exploration well MH-2, and the Bostic 1A well. City of Mountain Home lies at the intersection of HW-20, HW-30, HW-51, and HW-67; the Snake River and C.J. Strike Reservoir cross the lower half of the map. 3

Figure 3.0-1. Drilling operations at sunset, MH AFB. Drill rods on rack in front of the CS-4002 drill rig; core extraction station on right. Staff Scientists talk with driller while waiting for core retrieval

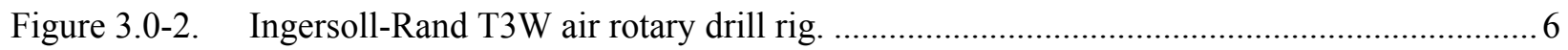

Figure 3.1-1. As-drilled well schematic (not to scale) .................................................................... 8

Figure 3.2-1. Drilling progress at Mountain Home AFB for Holes MH-2A and 2B. ......................... 10

Figure 3.4-1. Picture of the plugging and abandoning process. ......................................................... 13

Figure 4.1-1. Graphic log of lithologic units in MH-2 well (composite of MH-2A and MH-2B) showing basalts, lacustrine sediments, and (from 1200-1530 m) intercalated lava flows, hyaloclastites, and basaltic sandstones. Superimposed are the OSG gamma $\log$ and temperature profiles. From Shervais et al 2013.

Figure 4.1-2. Geophysical results include measurements from the manual logging with the DOSECC tool, three different measurements on parts of the BHTV (motor, head,

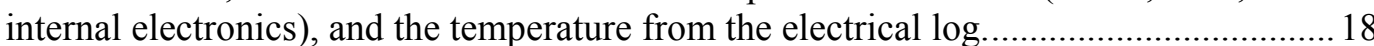

Figure 4.3-1. MH-2 thermal gradient log from BHTP compared to MH-1 …...................................... 20

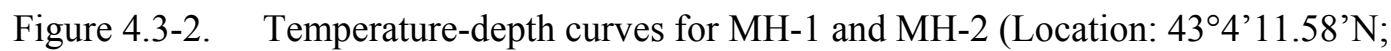
$\left.115^{\circ} 53^{\prime} 34.76^{\prime \prime} \mathrm{W}\right)$. Th (P) and Th (S) show primary and secondary fluid inclusion temperatures. The green triangle shows the temperature recorded in the hole while fluid was flowing to the surface. The location of the fluid entry at $1745 \mathrm{~m}$ is also shown

Figure 4.4-1. Chemistry of artesian geothermal water from MH-2B. (A)

Sulfate-Chlorine-bicarbonate ternary. $\mathrm{MH}-2$ waters are relatively rich in sulphate, suggesting equilibration with mafic volcanic rocks; all other southern Idaho thermal waters are bicarbonate rich, except for two springs near Camas. (B) $\mathrm{Na}-\mathrm{K}-\mathrm{Mg}$ ternary. MH-2 waters are partially to fully equilibrated with equilibrium temperatures of $150-160^{\circ} \mathrm{C}$. (C) Plot of $\partial 18 \mathrm{O}$ vs $\partial \mathrm{D}$. MH-2 geothermal waters fall on mixing line between meteoric water and volcanic water; all other southern Idaho thermal waters fall on the meteoric trend line. These data indicate that the MH geothermal system is distinct from other thermal systems in Idaho, which represent meteoric water that has been heated by deep circulation on faults. 
Figure 7.0-1. Drilling costs for production well vs. for slim hole well in 2010 dollars.

Figure A.1-1. Open fractures in NA-size core (2" diameter) lined with chlorite and prehnite. Depth 5756 feet, just below the artesian flow zone.

Figure A.1-2. Geothermal breccia cemented with quartz and calcite. The breccia implies steam explosions during older, higher temperature phase. Core $=2 "$ across.

Figure A.1-3. Ore minerals pyrite and chalcopyrite in gangue matrix of quartz and calcite. Core $=2$ " diameter.

Figure A.1-4. Second image of ore minerals pyrite and chalcopyrite in gangue matrix of quartz and calcite. Core $=2$ " diameter.

Figure A.2-1. On site core processing. Top: View of the core processing tent showing core trays, processing table, photo stand, and slab saw. Above Left: PVC core trays inside the core processing tent. Above right: Close up of lower end of PVC core tray (RED) with core and driller's wooden end block showing depth; amount cored and recovered shown on side of block.

Figure B.3-1. Drilling-induced fracture classifications as a result of tensile fractures in core (modified from Schmitt et al., 2012).

Figure B.4-1. Fracture frequency distribution plotted as fracture density (\# fractures $/ 5 \mathrm{ft}$ of borehole depth).

Figure B.4-2. Fracture frequency distribution plotted as cumulative fracture frequency. .................... B-5

Figure B.4-3. Aperture histogram depicting the distribution of apenure sizes in the ZOI................... B-6

Figure B.4-4. Equal-area, lower-hemisphere stereonet plot of the poles-to-plane for fractures over the ZOI.

Figure B.4-5. Rose diagram depicting the distribution of fracture dip azimuths. B-8

Figure B.4-6. Rose diagram depicting the distribution of dip angles from alIfractures in the ZOI. B-8

Figure D.4-1. Picture of flowing artesian water from a depth of $1750 \mathrm{~m}$ (5740 feet). D-4

\section{TABLES}

Table 6.2-1. Estimated costs for the potential Mountain Home AFB geothermal project. .29

Table B.4-1. Depths and apertures of large voids in the ZOI. B-6

Table D.1-1. Compositions, measured and geothermometer temperatures of MHAFB well \#2 ......... D-2

Table D.2-1. Chemical analysis of the geothermal water. D-2 
INTENTIONALLY BLANK 


\section{ACRONYMS}

DOE U.S. Department of Energy

DOSECC Drilling Observation and Sampling of the Earth's Continental Crust, Salt Lake City, UT

INL Idaho National Laboratory

IDWR Idaho Department of Water Resources

MH Mountain Home

MHAFB Mountain Home Air Force Base

SRP $\quad$ Snake River Plain

USGS U.S. Geologic Survey

USU Utah State University 
INTENTIONALLY BLANK 


\section{Mountain Home Air Force Base, Idaho Geothermal Resource Assessment and Future Recommendations 1. INTRODUCTION}

The purpose of this report is to summarize the activities that were associated with the exploration and assessment of a slimhole geothermal test well that was drilled at the Mountain Home Air Force Base (MHAFB) during 2011-2012. The report will detail the siting of the well location, design of the well, drilling of Mountain Home (MH) Wells \#1 and \#2, collection and analysis of core, geophysical logging temperature analysis, analysis of clay mineralogy and sampling and analysis of well water.

The Air Force has established a goal to generate 1 gigawatt of renewable energy by 2016. MHAFB is supporting this goal by investing in this collaborative effort to drill a new exploratory geothermal well. Currently, the base's maximum electrical power requirement is 14 megawatts. Idaho Power supplies electricity for the base and has been a reliable proponent and supporter of renewable energy projects throughout the State of Idaho and MHAFB. Grasmere Radar photovoltaic array site, in continuous operation since 1995, is a prime example of Idaho Power's commitment to renewable energy and continuous service. Elmore County also encourages the base's commitment to attracting new missions and private development. The vast amount of land surrounding the base provides potential for Air Force mission growth and commercial development.

The base is currently evaluating new missions as presented by HQ AF, which are favorable from multiple perspectives, both foreign and domestic. Geothermal power for the base can provide secure baseline power and support goals recently outlined by the Department of Defense Operational Energy Strategy. From a developer's standpoint, a geothermal power plant could provide renewable credits, a revenue stream from excess power, and a long-term, power purchase commitment. At this time, current power requirements will not change and steady growth in support of new missions is anticipated.

Site selection of the MH-2 drill hole was based on several lines of evidence that gave encouragement that a geothermal resource might be located in this area. A prominent regional Bouguer gravity anomaly that extends from the Boise area to the southeast has been shown to represent an uplifted horst block in the subsurface, especially near Boise itself (Wood, 1994). The extension of this same gravity high to the Mountain Home area is shown in Figure 1.0-1 and Figure 1.0-2. The MH-1 drill site was located on the southern edge of the gravity high on the eastern edge of Mountain Home AFB. The MH-2 drill site was chosen in the NW corner of the base, near the contractor's entrance to be on the southern flank of the prominent gravity high, as shown in Figure 1.0-1.

Ground water temperature anomalies in surrounding wells were also examined as a possible guide to warm water upflow, but the paucity of wells, a thick layer of lake bed sediments and the influence of cold waters from the Canyon Creek drainage west of MHAFB makes temperature mapping of groundwater an unreliable indicator of deep thermal upflow. 


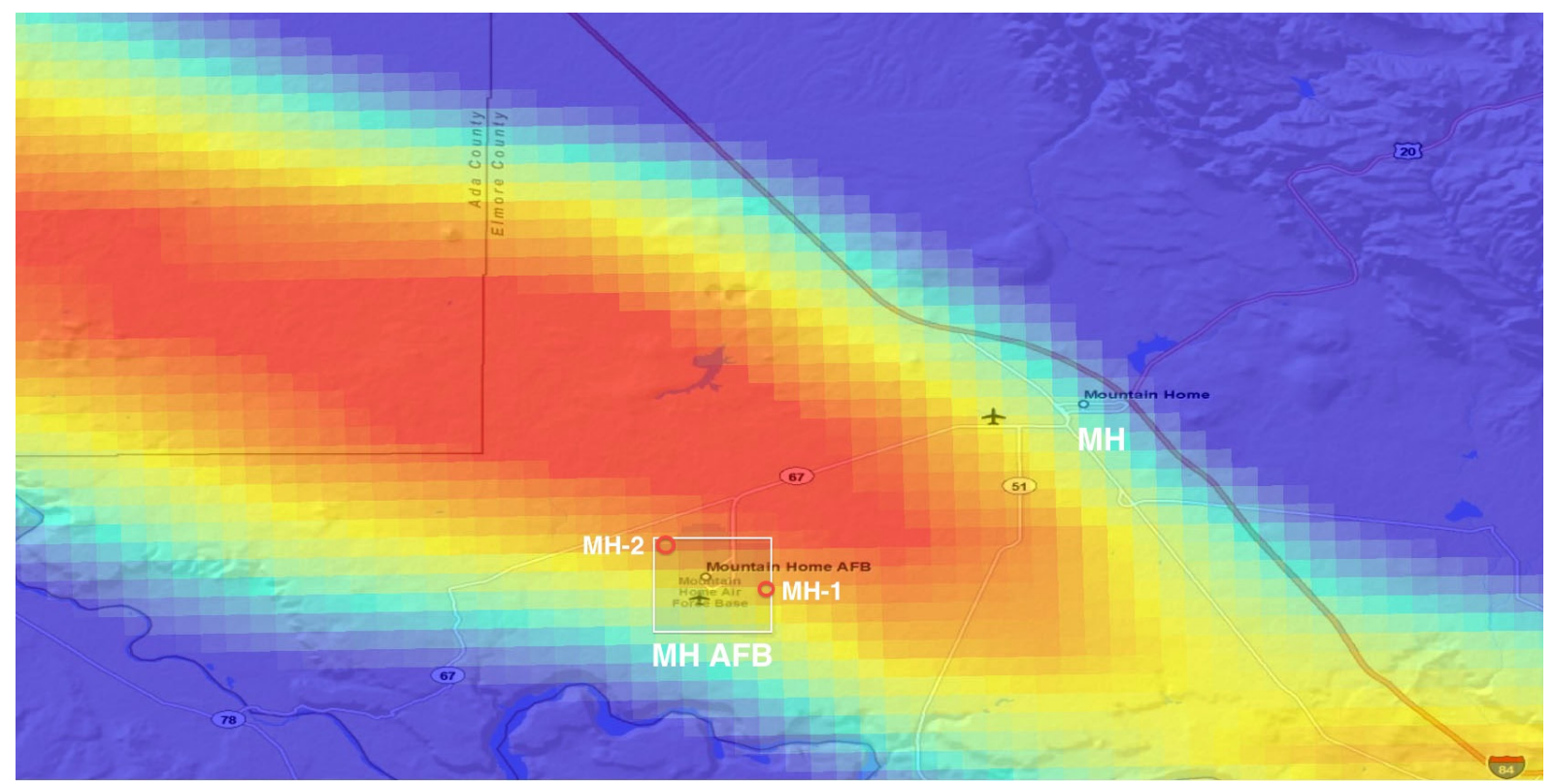

Figure 1.0-1. Regional Bouguer gravity anomaly near Mountain Home Air Force Base, Idaho, using existing State gravity database. Warm colors are gravity highs, cool colors are gravity lows.

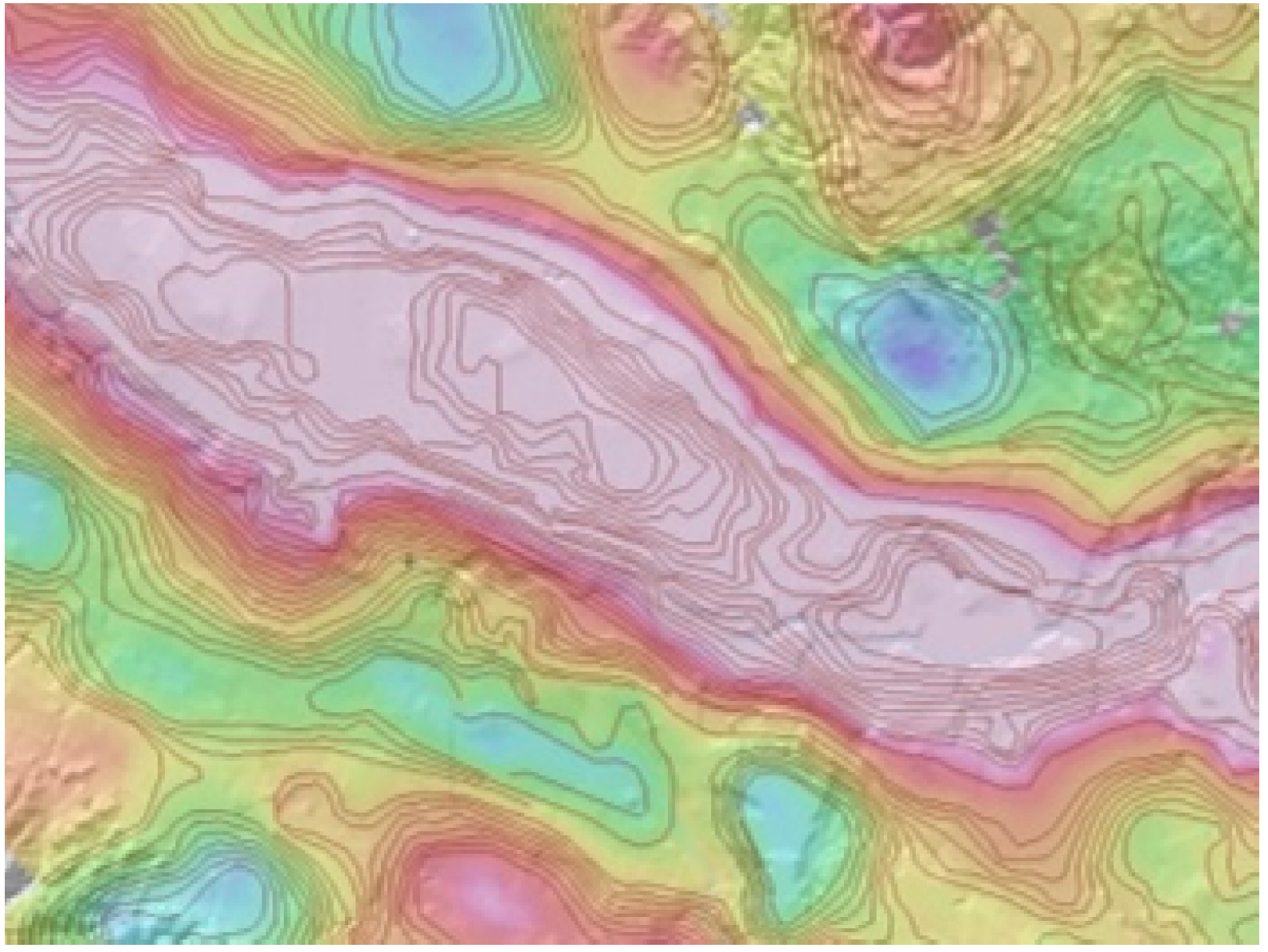

Figure 1.0-2. Regional Bouguer gravity anomaly near Mountain Home Air Force Base, Idaho, based on new high-resolution gravity (Glen, USGS). Warm colors are gravity highs, cool colors are gravity lows. 


\section{SETTING}

The MHAFB is located on a high desert plateau between two large mountain ranges, Mountain Home AFB is situated about 50 miles southeast of Boise and 90 miles northwest of Twin Falls, Idaho. The city of Mountain Home, Idaho has a population of approximately 17,000.

Mountain Home Air Force Base is home to the 366th Fighter Wing, the "Gunfighters." The 366th Fighter Wing is a member of an air expeditionary force. The Wing blends the firepower of F-15C Eagles and the F-15E Strike Eagles, to form a cohesive aerial strike force.

The Snake River volcanic province overlies a thermal anomaly that extends deep into the mantle and represents one of the highest heat flow provinces in North America (Blackwell and Richards, 2004). This makes the Snake River Plain (SRP) one of the most under-developed and potentially highest producing geothermal districts in the United States. Elevated heat flow is typically highest along the margins of the topographic SRP and lowest along the axis of the plain, where thermal gradients are suppressed by the Snake River aquifer. Beneath this aquifer, however, thermal gradients rise again and may tap even higher heat flows associated with the intrusion of mafic magmas into the mid-crustal sill complex (e.g., Blackwell, 1989).

Geothermal power has long been used in southern Idaho, but it has been confined almost exclusively to direct use applications such as space heating and aquaculture (e.g., Mitchell et al., 1980; Neely, 1996). There is only one site where geothermal resources are used for power generation, the Raft River Valley site (Peterson et al., 2004; Neely and Galinato, 2007). The potential for power generation is significant, especially using binary generation systems that can exploit lower temperature resources (Sanyal and Butler, 2005; Neely and Galinato, 2007).

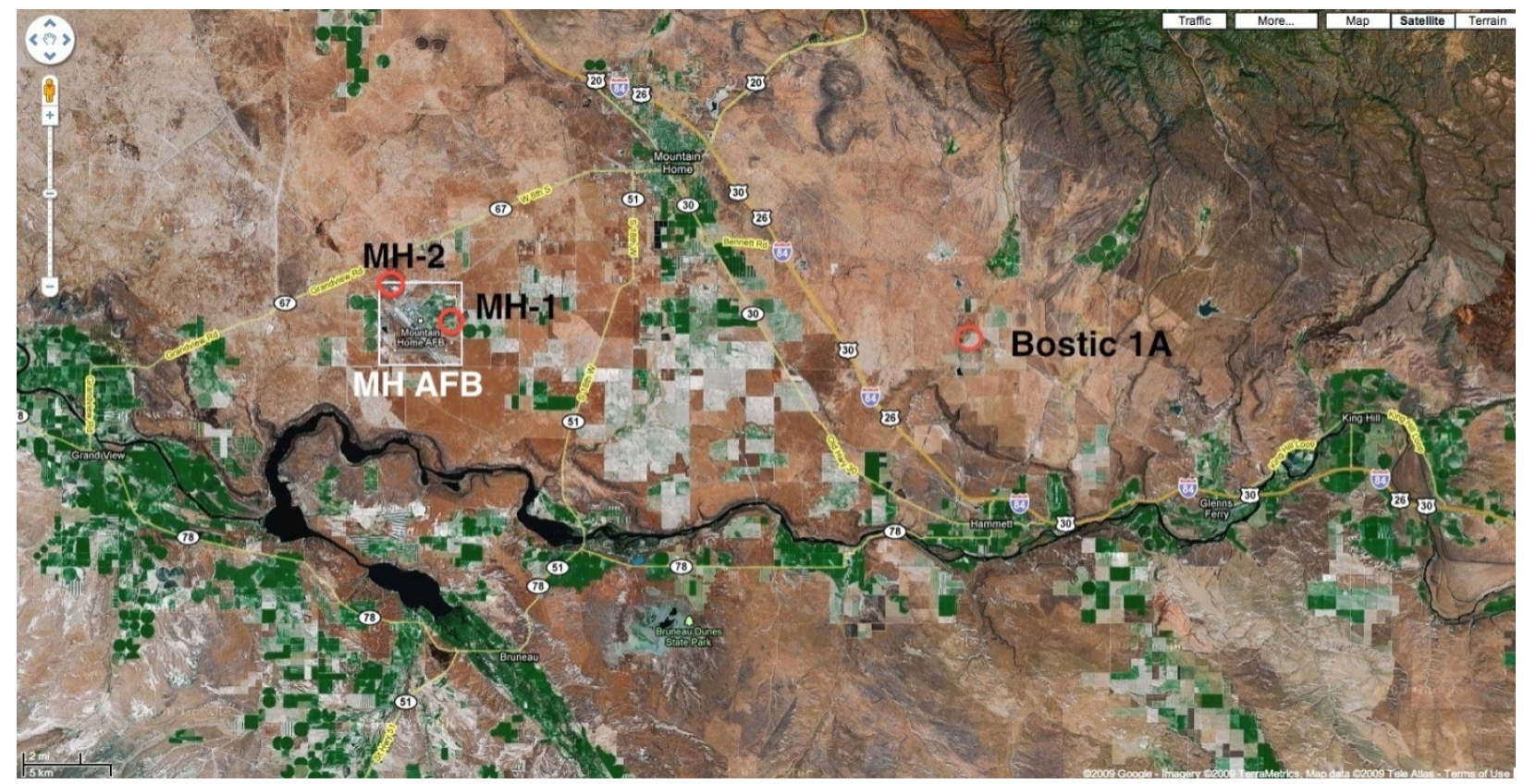

Figure 2.0-1. Map showing the location of Mountain Home AFB, Idaho, as well as the 1986 geothermal exploration well MH-1, the new geothermal exploration well $\mathrm{MH}-2$, and the Bostic 1A well. City of Mountain Home lies at the intersection of HW-20, HW-30, HW-51, and HW-67; the Snake River and C.J. Strike Reservoir cross the lower half of the map. 
The geothermal potential of deep drill holes in the western Snake River Plain was first suggested by the Bostic 1A well, a wildcat oil well drilled to a depth of 9676 feet in 1973, and subsequently acquired by Gulf Resources as a geothermal prospect (Arney et al., 1984). This well, located 12 miles southeast of Mountain Home, Idaho (see Figure 2.0-1), had a bottom hole temperature (BHT) of $175^{\circ} \mathrm{C}$ at $2949 \mathrm{~m}$ (9676 ft). Union Oil acquired the well a few years later and was the focus of a Hot Dry Rock investigation by researchers from Los Alamos National Laboratory (Arney, 1982; Arney et al., 1982; 1984).

The high geothermal gradient in Bostic $1 \mathrm{~A}\left(59^{\circ} \mathrm{C} / \mathrm{km}\right)$ stimulated an interest in geothermal power potential on Mountain Home AFB. In 1986, a 4404-foot deep test well (MH-1) was drilled at Mountain Home Air Force Base (MHAFB) to test for geothermal resources (Lewis and Stone, 1988). This well documented a temperature of $93^{\circ} \mathrm{C}$ at 4000 feet depth $\left(69^{\circ} \mathrm{C} / \mathrm{km}\right.$ thermal gradient), which was too low for use with existing technology at the time. Advances in geothermal technology since then suggest that temperatures high enough to produce power using binary cycle technology may exist at depths of 5000-6000 feet under the base. The MH-1 geothermal test well was plugged and abandoned shortly after drilling, so it is no longer available for further testing.

Idaho National Laboratory (INL) teamed with Utah State University (USU) and the Air Force at Mountain Home to drill a new geothermal gradient test well located on Mountain Home AFB to further investigate fluid flux, temperature gradients, and the potential for geothermal energy development. The goal of this project was to drill a temperature gradient well to a depth of over 5000 feet, with the final actual depth dependent on drilling conditions, rate of progress, and financial constraints. This drill hole was planned as an extension of the shallow test well drilled as part of "Hotspot: the Snake River Geothermal Drilling Project", at a site located in the NW corner of Mountain Home AFB. Project Hotspot is an effort that is supported by a U.S. Department of Energy (DOE) contract (DE-EE-0002848) to drill three different wells across the Snake River Plain to evaluate the potential for geothermal energy resources (Shervais et al., 2011). The well at MHAFB is the third and final well drilled for Project Hotspot. MH-1 was drilled in two Phases to differentiate funding sources. As part of Phase 1 drilling at MHAFB, Project Hotspot produced a 2748 feet deep core hole that extended through the Pliocene lake deposits into basalt (this is the upper part of this well, MH-2). Project Hotspot also produced detailed seismic, magnetic, and gravity profiles across the proposed drill site to aid in interpretation of the geothermal potential of the area.

Phase 1 drilling by Project Hotspot employed slim-hole diamond core drilling to recover HQ-size core from the upper 2748 feet of the new test well. Phase 1 drilling was funded by the U.S. Department of Energy and the International Continental Drilling Program. This hole was logged to provide a complete record of lithology and physical properties, including fracture distribution, porosity, permeability, and density. Upon completion of Phase 1 drilling by Project Hotspot, the USAF assumed ownership and continued drilling as the Phase 2 Mountain Home Geothermal Drilling Project. To save money, the same drilling rig, team and approach were employed. The design and results of the drilling process are detailed in this report. 


\section{WELL DESIGN AND DRILLING OPERATIONS}

Geothermal environments pose unique challenges for exploration, reservoir assessment and production drilling. For exploration and assessment purposes, coring presents the advantage of observing reservoir lithologies, hydrothermal mineralogy and fluid inclusions, fracture character as well as offering the opportunity to measure down-hole temperature (Hulen and Nielson, 1995; Nielson et al., 1996; Nielson et al., 1998). Reservoir engineering data can be acquired from slim-holes (Garg and Coombs, 1997). The cost of core drilling is known to be lower than production well drilling, and coring can be done to the depths of production wells (Nielson, 2001). These factors have led many companies to conduct core drilling prior to the more expensive, larger diameter production drilling. Attempting to achieve all three objectives in a single hole in a cost effective manner is difficult and there are few other projects that document the operating experience and costs along with the scientific benefits of coring as is presented in this report.

The Hotspot Project was designed to evaluate three different geothermal environments in the Snake River Plain (SRP) (Shervais et al. 2012). The effect of fresh water aquifers cooling the high heat flow from this large magmatic province is well established (Blackwell, 2011). Because of this, deep coring was necessary to penetrate below the base of the cold water aquifers.

The MH-2 well was permitted by the Idaho Department of Water Resources (IDWR) Geothermal Division, Permit Number 61-GR-08. IDWR regulations for geothermal test wells require that 0.25 -inch wall steel casing is set to $10 \%$ of total depth, being sealed in the borehole with a 1-inch annulus of cement. This requirement allows the well to be controlled if a geothermal steam blow out occurs. This drilling safety requirement made it more cost effective on $\mathrm{MH}-2$ to drill the upper $10 \%$ of the well depth with an air rotary drill rig, which is capable of drilling large diameter wells to moderate depths quickly and cheaply (although they are depth-limited by the lift-capacity of the air compressors). After the steel casing is cemented in place the lower $90 \%$ of the test hole was cored. The coring took place from September of 2010 through October of 2011.

All core drilling, was performed by DOSECC Inc. (Drilling Observation and Sampling of the Earth's Continental Crust) of Salt Lake City, Utah, and under Idaho well drillers license 656. Air rotary services were performed by Eaton Drilling and Pump Services of Wendell, Idaho, and under Idaho well drillers license 026. An Atlas Copco CS-4002 coring rig was the primary drilling platform used throughout the project shown in Figure 3.0-1. All work done by Eaton Drilling and Pump Service was accomplished with an Ingersoll-Rand T3W air rotary drill rig using down hole hammers shown in Figure 3.0-2. 


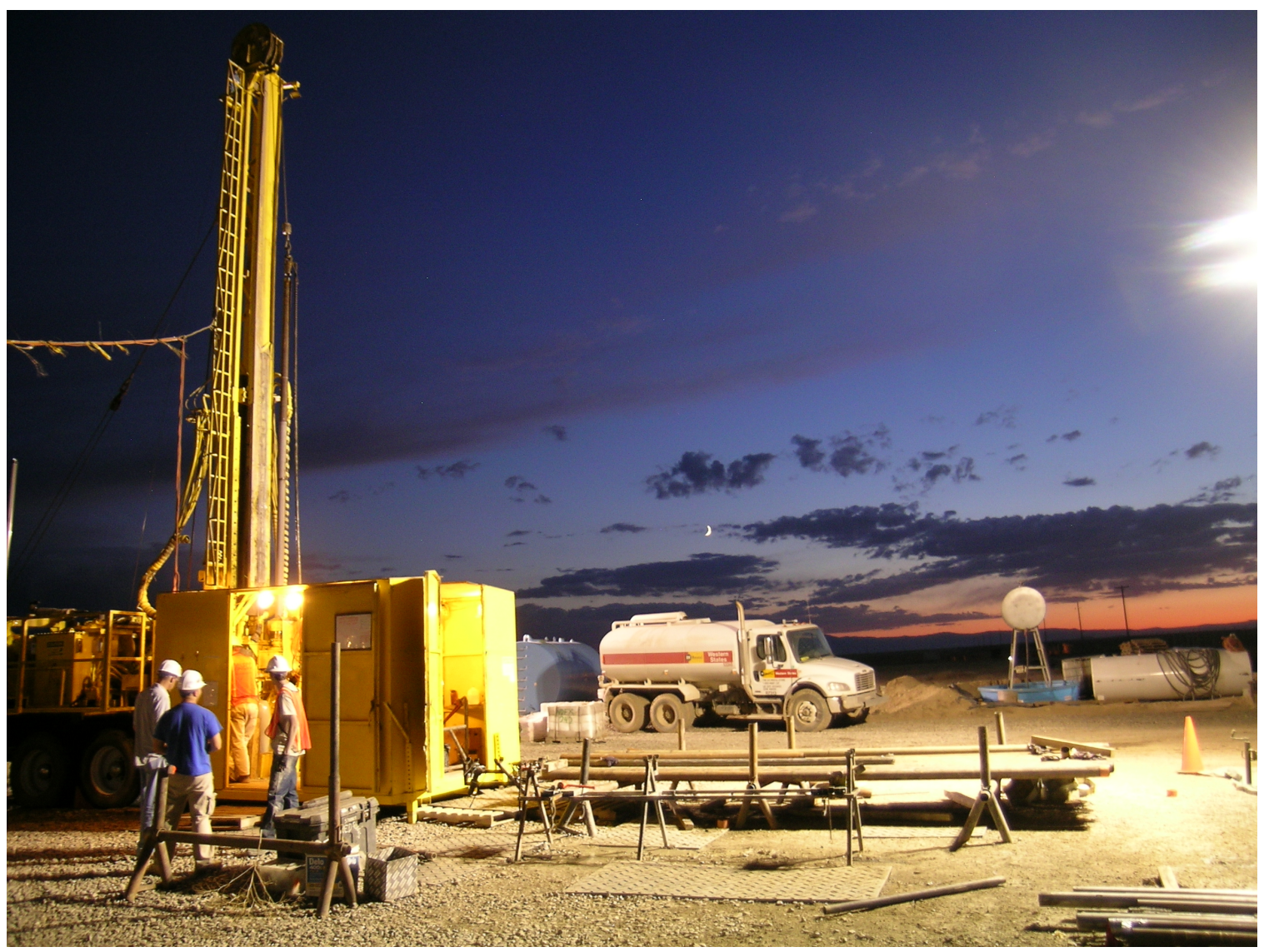

Figure 3.0-1. Drilling operations at sunset, MH AFB. Drill rods on rack in front of the CS-4002 drill rig; core extraction station on right. Staff Scientists talk with driller while waiting for core retrieval.

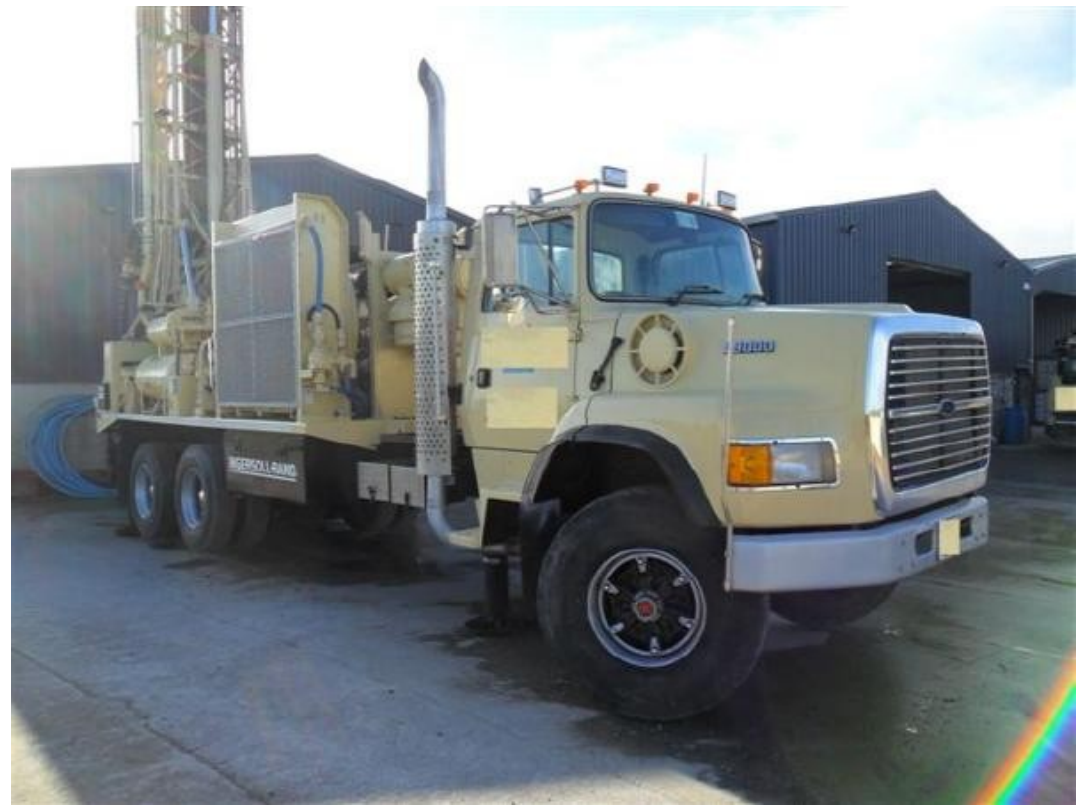

Figure 3.0-2. Ingersoll-Rand T3W air rotary drill rig. 


\subsection{Well Design}

The original drilling and logging plan for the well was worked out during the Snake River Scientific Drilling Project Technical Workshop held in Twin Falls in September 2009, which included personnel from DOSECC, ICDP, the INL, USGS, and various universities involved in the project. Subsequently, meetings were held with DOD and MHAFB staff, INL scientists and the "Project Hotspot" Drilling Team to discuss well construction and testing. The well was designed to be drilled in stages and logged between stages to accommodate the multiple engineering and scientific objectives of the project. A well schematic diagram prior the well being plugged and abandoned (P\&A) is shown in Figure 3.1-1.

In addition to satisfy the many technical objectives, the well design also had to meet all State of Idaho Well Drilling and Construction Standards in accordance with the Idaho Geothermal Resource Act. Well design, well drilling and well construction in the State of Idaho are administered by the Idaho Department of Water Resources (IDWR). The well design was reviewed and approved by IDWR on June 1, 2011 with the specification that the well be properly decommissioned within one year of initiating drilling. Injection and/or production of geothermal resources were not authorized under the permit. On June 18, 2012, IDWR issued a six month extension on the drilling permit to allow the well to remain open for testing. The well was required to be decommissioned on or before December 23, 2012. The project met all the terms of the well drilling permit and its extension. 


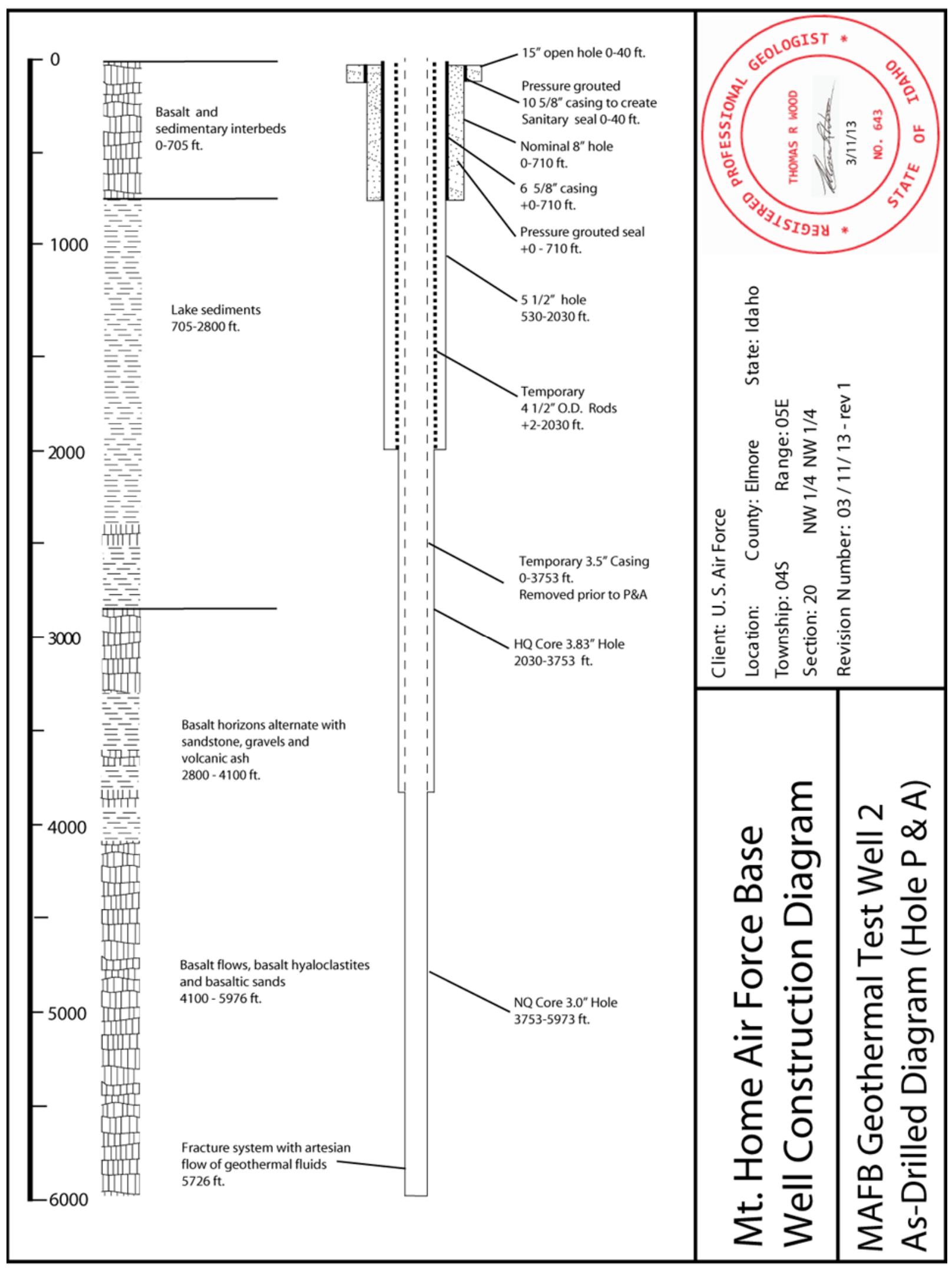

Figure 3.1-1. As-drilled well schematic (not to scale). 


\subsection{Drilling of Mountain Home Well \#2a and \#2b 3.2.1 Mountain Home MH-2 Well (43 4'11.57'N $\left.115^{\circ} 53^{\prime} 34.61^{\prime \prime} \mathrm{W}\right)$}

The Mountain Home MH-2 well site is located on the northwestern corner of Mountain Home Air Force Base, approximately $1 / 4$ mile east of the Grandview gate. Drill pad access is restricted to those with valid U.S. Government identification. This site was allocated to the project by the 366th Civil Engineering Squadron Mission Support Group. Site preparation was also provided by the 366th mission support group.

Drilling and coring was carried out by DOSECC, Inc., of Salt Lake City, Utah, using an Atlas Copco CS-4002 diamond drill rig with a rated depth capacity of $8400 \mathrm{fbs}$ with NQ drill rod. DOSECC also served as the prime contractor to provide logistical support to science team and contracted for the water well driller (Eaton Drilling and Pump Services). Eaton Drilling drilled and set the surface conductor casing, and drilled and cased the upper 530-705 feet of each hole, using an Ingersoll-Rand air rotary rig. This allowed penetration of the upper part of the section quickly with a large diameter hole that could be cased to IDWR requirements for a geothermal test well.

\subsubsection{Mountain Home Drilling History}

Mountain Home test 2A on IDWR geothermal application 61-GR-08 was spudded on June 24, 2011. Eaton Drilling and Pump Services drilled and set a 40-foot pressure grouted surface seal and then drilled to 530 feet below surface (fbs) through the basalt cap to the depth where the top of the lake sediments were expected to be based on other nearby well logs. DOSECC Inc. moved on the hole and started coring from $530 \mathrm{fbs}$ to $705 \mathrm{fbs}$ through massive basalt. Coring continued from $705 \mathrm{fbs}$ to $1967 \mathrm{fbs}$ through sand and intermittent clay layers. At this depth the rods became stuck and drill crews worked for several days to free the rods. It was decided that it would be more cost effective to abandon this hole (MH-2A) and to start a new hole. The drill rod was cut above the stuck interval and retrieved for reuse. The new hole (MH-2B) was offset 20 feet from MH-2A. Eaton Drilling and Pump Services drilled and set a new 40-foot pressure grouted surface seal then drilled to $705 \mathrm{fbs}$ through the basalt cap to the lake sediments.

The CS-4002 Drill Rig was moved over the hole and DOSECC rotary drilled through the sediments to $2030 \mathrm{fbs}$. Upon reaching $2030 \mathrm{fbs}$ in MHAFB test 2B and still in the lake bed sediment, the temporary casing was landed to ease drilling difficulties. HQ core was drilled out the bottom of the temporary casing. HQ coring continued to $3753 \mathrm{fbs}$ on October 29, 2011. NQ coring commenced after landing the HQ as a temporary casing string. Drilling was suspended over Christmas and New Year's from December 8,2011 - January 15, 2012 to allow invoices to clear so that an accurate budget review could be performed. On January 15, 2012, the geophysical surveys began and lasted through January 22. NQ coring recommenced and advanced to $5640 \mathrm{fbs}$ where lost circulation began to develop and at $5726 \mathrm{fbs}$ on January 26, 2012 , water under artesian pressure flowed at $11 \mathrm{gal} / \mathrm{min}$. Water sampling was performed and drilling continued using a heavy barite mud to balance the upwards pressure. NQ coring advanced to the total depth of the hole of $5976 \mathrm{fbs}$ on January 31, 3012. The total depth of the hole was called due to budget constraints. Drilling progress at Mountain Home is shown in Figure 3.2-1. 


\section{SRP: Mountain Home Phase I Cumulative Drilling Depth}

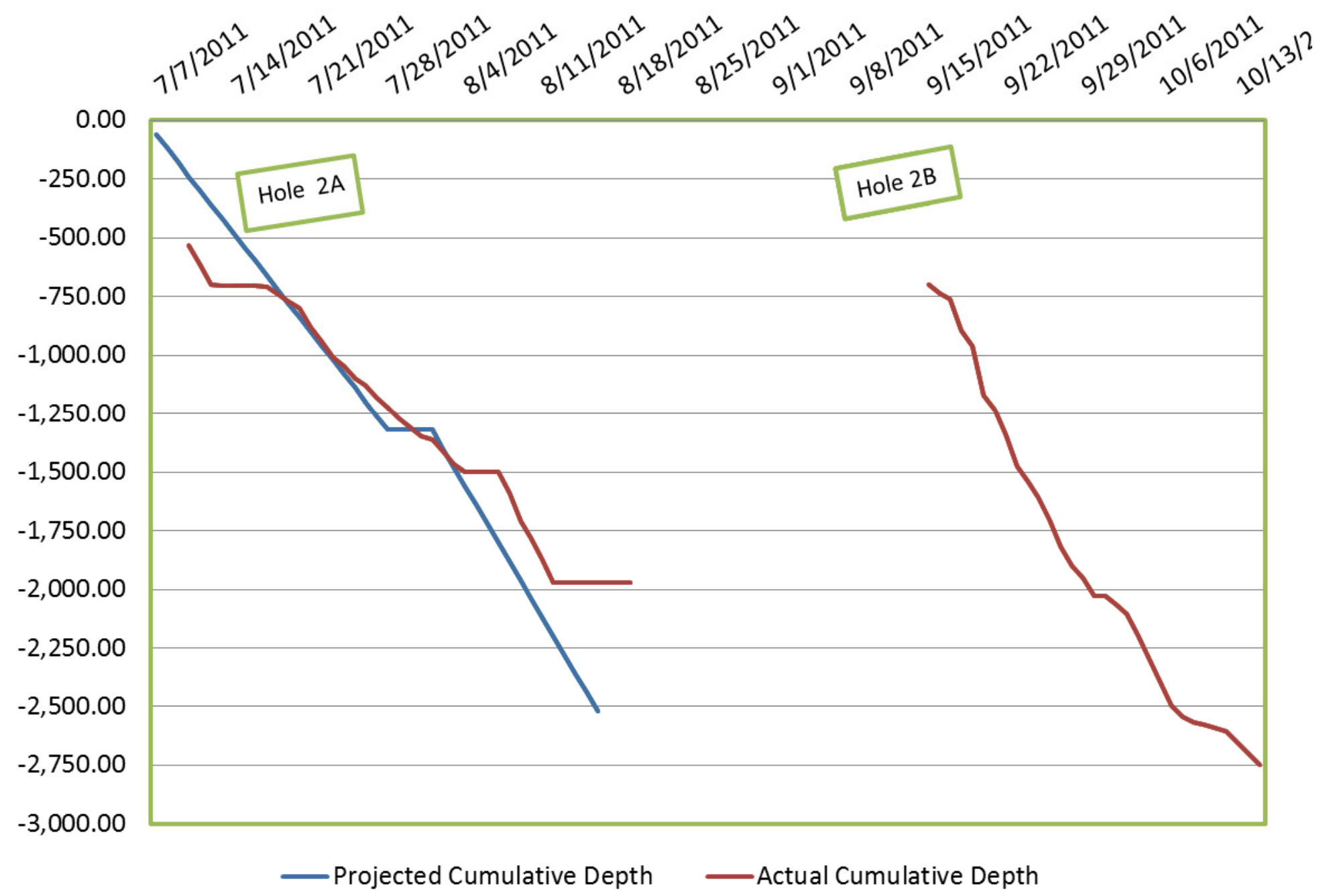

Figure 3.2-1. Drilling progress at Mountain Home AFB for Holes MH-2A and 2B. 
MHAFB Phase 2 - Drilling Depth

0.00

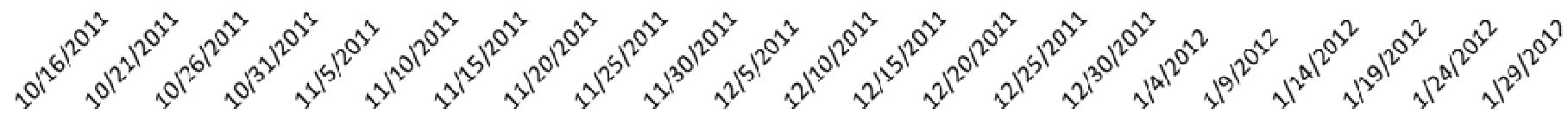

Key Decisions for MHAFB Phase 2:

1.) Rotary dril upper 710 feet

a.) Time constraint

b.) Maximize deoth to cost

2.) Rotary through Lake Sediments and Set HWT

3.) HQ Core to $3000 \mathrm{fbs}$

4.) Finish the hole with $\mathrm{NQ}$

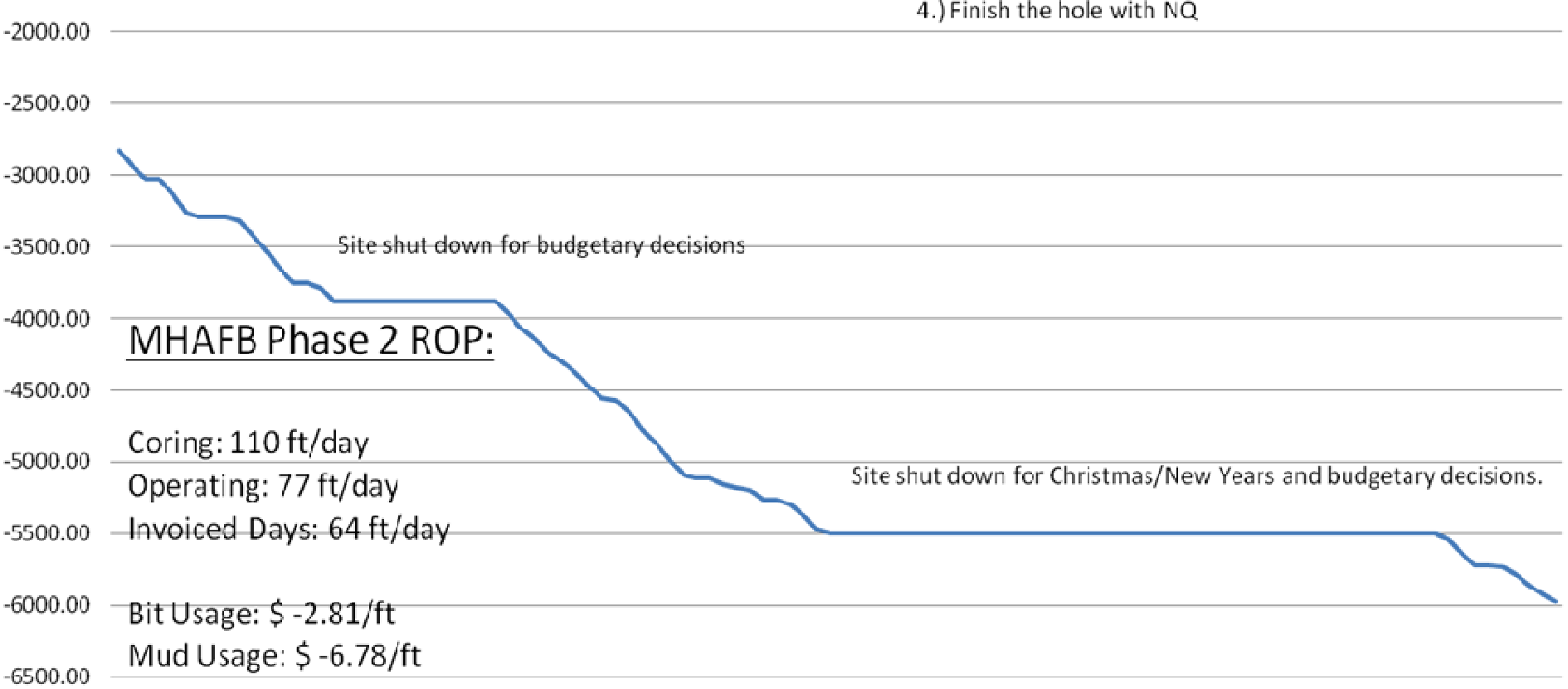

—-Actual Cumulative Depth

Figure 3.2-1 (con't). Drilling progress at Mountain Home AFB for Holes MH-2A and 2B. 


\subsection{Coring Operation and Analysis of Core}

Core recovery, descriptions, logging, boxing and labeling was performed by the Snake River Scientific Drilling Project, primarily Utah State University. Considerable care and attention was rendered in this operation as it provided the framework for all subsequent sampling and scientific study of the core. The core procedures and analysis are presented in detail in Appendix A.

\subsection{Final Plug and Abandonment of Well \#2a and \#2b}

DOSECC, Inc., remobilized to Mountain Home on November 6, 2012, to plug and abandon (P\&A) the hole. There was considerable discussion among the project team concerning the advantages of leaving the hole open as a monitoring well, however, the IDWR did not approve of allowing the hole to be left as a monitoring well.

The CS4002 drill was set up on 11/07/12. The annular blow out preventer (BOP) was nippled up, and the 2-3/8" tubing was connected and 1500 feet of 2-3/8" liner was tripped into the hole. There was no upward flow of water from the hole. The liner was out of the hole by 15:00 on 11/08/12. The drillers then ran NQ rods in the hole and made temperature measurements with the DES temperature tool at 4200, 4800, 5600, 5720, and $5976 \mathrm{fbs}$ (TD). No obstructions were encountered in the hole. Mud was circulated in the hole on 11/10/12 to reduce the bottom hole temperature in preparation for open hole logging. The NQ rods were withdrawn, and South West Exploration spent 11/11/2 and 11/12/12 logging the open hole.

The drillers then attempted to spear and retrieve the HQ rods that were landed at 3753 feet, on the morning of 11/13/12. However, the rods were stuck, so the drillers tripped out and ran in the rod cutter. Several attempts were made to cut and pull the HQ rod. The drillers were able to get the HQ rods cut and removed $3547 \mathrm{ft}$ of HQ rod. A HQ bowen spear and NQ cutter were both lost with $1135 \mathrm{ft}$ of NQ rod to the bottom of the hole while trying to cut and fish. The drillers had the HQ rods out on 11/15/12 and tried to connect to the PQ rods. The PQ rods were in tight with barely any stretch. Three different attempts were made to cut the PQ at 1500, 1000, and 800 feet. All 3 attempts failed. The PQ rods were abandoned, and the NQ rods were tripped in to tremie cement. On 11/19/12, with a representative from IDWR present, the neat cement slurry was pumped down the tremie pipe to a depth of 4841 feet to the top of the NQ rod. In lifts of $1000 \mathrm{ft}$ and volumes of 5 cubic yards, the hole was plugged with a total of 25 cubic yards of $15.5 \mathrm{lb} /$ gallon neat cement. Cementing was accomplished by $11 / 19 / 12$. The PQ casing was cut off 3 feet below grade, and the $3 \mathrm{ft} \times 3 \mathrm{ft} \times 3 \mathrm{ft}$ cement cellar was filled with cement as a monument on instructions from USAF personnel. The equipment was rigged down on 11/20/12, and the site was cleaned, leveled and pits backfilled. A representative of the USAF approved the site, and all equipment was demobilized to Salt Lake City on 11/21/12. 


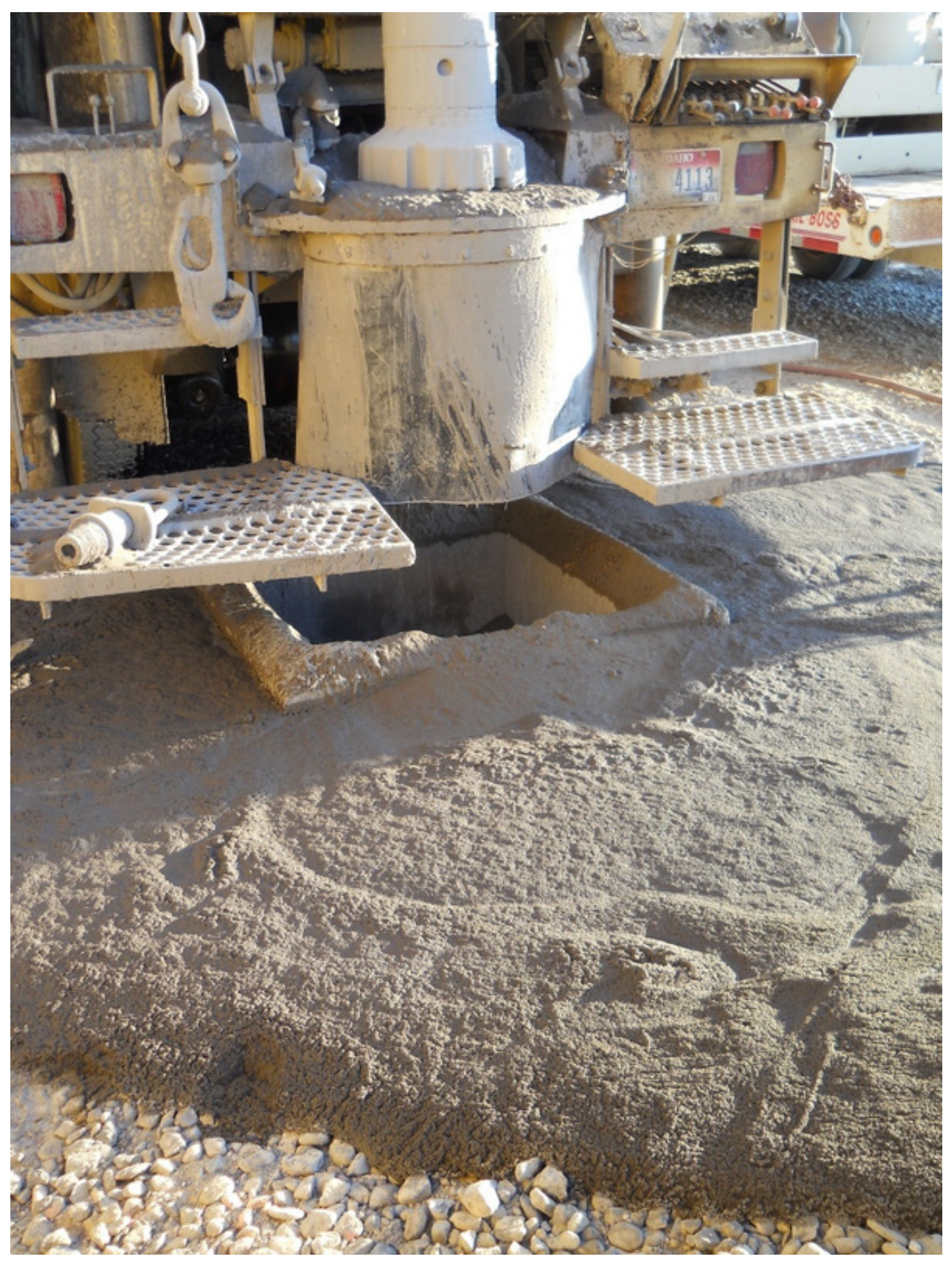

Figure 3.4-1. Picture of the plugging and abandoning process. 


\section{RESULTS \\ 4.1 Lithologic Logging}

Lithologic logging was carried out continuously as core was retrieved, with a more detailed assessment made after core was transported to the USU Core Laboratory (see Appendix C for details of core handling). We report here on basic lithologic logging of the core, and describe some of the more important features related to the Mountain Home Geothermal System.

A graphic log of the lithologies is shown in Figure 4.1-1, which includes as overlays the natural gamma log and two temperature profiles obtained by the ICDP Operational Support Group (see next section). The uppermost cored section (from 530 to 705 feet) consists of massive plagioclase phyric basalt flows with few obvious internal contacts and little no vesicularity. These flows are characterized by large "snowflake" clusters of plagioclase laths (variolitic texture) which are not observed in the older basalts, but are similar to plagioclase-rich textures in surface outcrops near Mountain Home (Shervais et al 2005).

From 705 feet to $\sim 2800$ feet depth the section consists of fine-grained sediments, typically mudstones and fine quartz sands, with rare thin basalt intercalations. The thickest basalt intercalation occurs at $\sim 2450-2550 \mathrm{fbs}$. Occasional layers of pebble conglomerate are rare but difficult to core. The fine sands are especially treacherous for core drilling as they tend to collapse in on the drill string. Coring the upper section (705-1967) feet was carried out with Lexan core barrel liners to facilitate sediment recovery.

There are four major units. Unit 1 consists of sand, sandy silt, and minor clay/gravel intervals (705-1453). Unit 2 is very fine sands (1453-1700 feet). The sediment is quite compacted and dense, not cemented to be "sandstone", but quite solid in the core. The entire unit is quite uniform, coarse lamination was apparent, well visible through the liner. Only thin intervals of this otherwise uniform sand unit consist of finer clayey silt, for example, around 1615-1625 feet. The bottom of this unit may be placed at $1697 \mathrm{ft}$, where there is a shift to medium sand and coarse sand, all quite well sorted. Unit 3 consists of coarse sand, compacted but not cemented (1700-1810 feet). Below 1720 feet this coarse sand contains abundant basalt clastic grains, and there are three layers of basalt, each about 1 foot thick at 1735, 1780, and 1787 feet (all depths are below rotary table, which was 6 feet above ground). At about 1810 feet, there is a sharp change from coarse sands of Unit 3 to fine clayey silt, this is the top of Unit 4 (1810-1950+ feet). Unit 4 is remarkably uniform - fine laminated clayey silt all the way to the bottom of MH-2A. Coring in MH-2B below 2000 feet continued in fine sands and silts, with thin basalt interbeds, to $2800 \mathrm{fbs}$. 

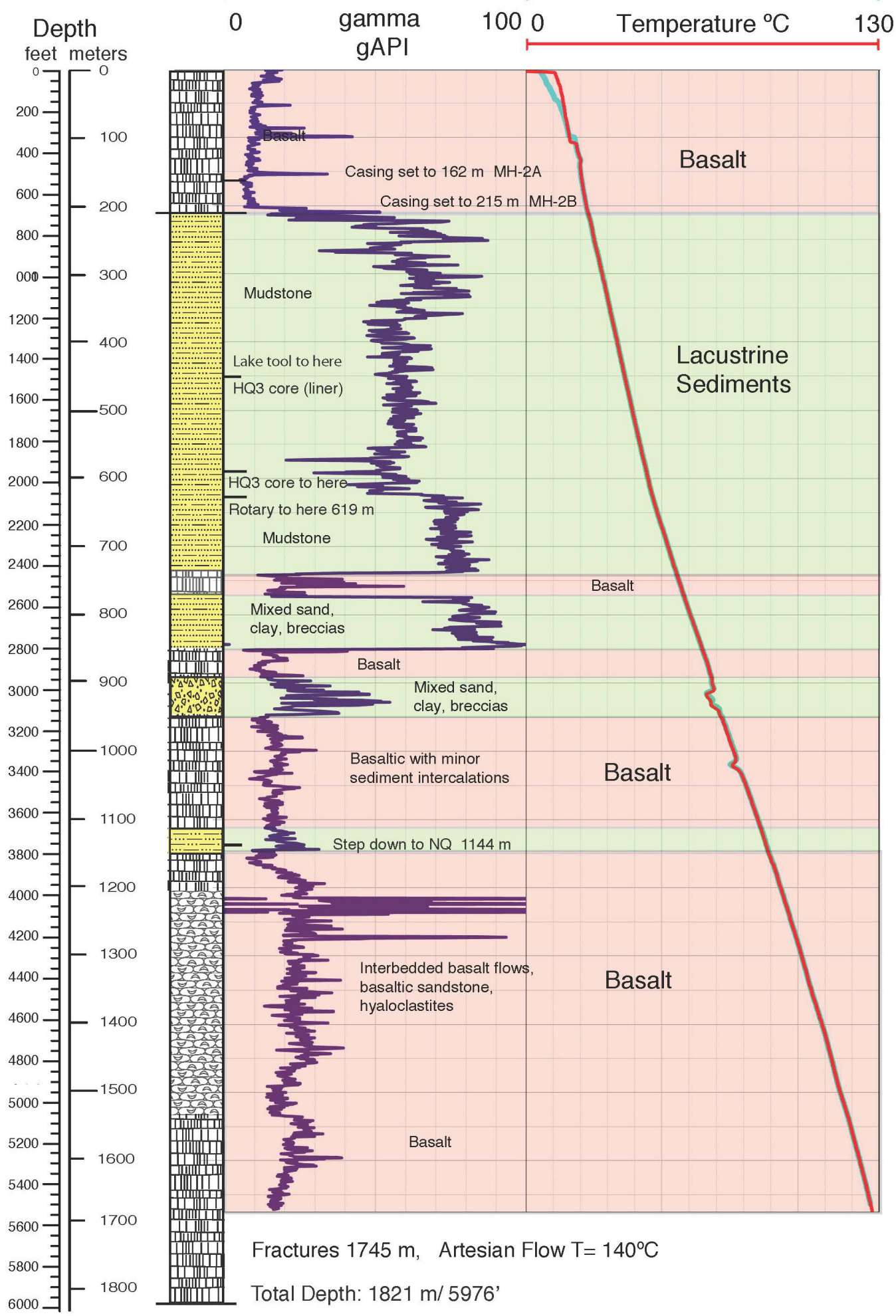

Figure 4.1-1. Graphic log of lithologic units in MH-2 well (composite of MH-2A and MH-2B) showing basalts, lacustrine sediments, and (from 1200-1530 m) intercalated lava flows, hyaloclastites, and basaltic sandstones. Superimposed are the OSG gamma log and temperature profiles. From Shervais et al 2013. 
From $2800 \mathrm{fbs}$ to $3950 \mathrm{fbs}$ the section is dominated by altered basalt with minor sediment intercalations, and two thick sediment layers (at 2950-3140 fbs and 3700-3800 fbs). The basalts are partially altered by hydrothermal solutions and are commonly characterized by a reddish tan color, consistent with oxidation and alteration to clays. Mineralized fractures are common, as breccias with calcite deposition sealing the pores. Below 3950 feet is a thick section of basalt flows, hyaloclastites, and basaltic sandstones/gritstones. Alteration is typically greenish tinged. At $\sim 5100 \mathrm{fbs}$, the hyaloclastites and basaltic sandstones give way to more massive basalt. Alteration is green and pervasive. Mineralized fractures are dominant, typically filled with calcite and quartz; additional minerals include pyrite and chalcopyrite (in crystals up to $1 \mathrm{~cm}$ across) within veins of quartz \pm chlorite (corrensite?). At $\sim 5740 \mathrm{fbs,}$ open fractures are lined with corrensite and laumontite, with corrensite on the fracture walls and laumontite deposited on corrensite. Apertures on the open fractures are over one inch across $(2.5 \mathrm{~cm})-$ almost the width of the core. Fractures of this width can transport water rapidly if connected to a major fracture network system.

The geothermal fluid zone at $5726 \mathrm{fbs}(1745 \mathrm{~m})$ consists of highly altered massive basalt with less than $50 \%$ core recovery. The low core recovery is consistent with large open apertures, whose throat size exceeds the diameter of the NQ core ( 2 inches).

\subsection{Geophysical Assessments}

Two logging campaigns were carried out, one in mid-January 2012 to the depth of $1676 \mathrm{~m}$ (5500 feet), primarily because of the discovery of the artesian flowing fracture near $1750 \mathrm{~m}$ (5740 feet), and a second more limited geophysical campaign on November 11-12, 2012.

The first round of geophysical logging and borehole seismic experiments, carried out by the International Continental Drilling Program 'Operational Support Group' under the leadership of Mr. Joachim Kueck with assistance from the University of Alberta and Utah State University, was completed from January 17-21, 2012. Temperature and natural-gamma logs were acquired with the drill string in place. Magnetic susceptibility, electrical, dipmeter, and sonic open hole logging was restricted to the $533 \mathrm{~m}$ of the drill hole (NQ section) from $1143 \mathrm{~m}$ to $1676 \mathrm{~m}$. Open hole logging was not carried out above these depths as the weak sediments in the upper part of the hole were unstable and it was deemed too risky to remove the HQ rods and PQ-size casing at that time. After completion of this logging, budgets allowed for additional core to be recovered and the hole was completed to $1821.5 \mathrm{~m}$. A $2^{3 / 8 \text {, liner }}$ was then placed to keep the hole open and allow formation to come to thermal equilibrium for final temperature logging.

The unexpected intersection of the artesian fracture zone motivated a final round of geophysical logging. Beginning on November 6, 2012 the steel liner was pulled and NQ drill string returned to TD in order to circulate cold water to allow for use of higher temperature logging tools. No noticeable difficultly was encountered in returning the NQ string to TD. Several well bore volumes of cold water were pumped into the formation with no returns to the surface indicating that the formation was taking up the water (i.e. significant native permeability exists in the formation). This circulation ended in the morning of November 11 and temperature measurements were obtained in the well using the DOSECC temperature tool, these indicated that little cooling of the well had taken place as the bottom hole temperature near $135^{\circ} \mathrm{C}$ was obtained.

A combined natural gamma- neutron logging tool was then run through the NQ drill string. After some initial difficulties with the tool, logging proceeded downwards from the surface to $1693 \mathrm{~m}$ at which point the neutron instrument failed. The natural-gamma tool failed much shallower at $1371 \mathrm{~m}$ (4500 feet). In principle, this tool is rated to $149^{\circ} \mathrm{C}$, it is not known if the temperature was the major cause of the loss of the neutron log. However, it is interesting to note that the amplitude of the neutron signal increases strongly towards the bottom; this may be related to temperature dependent effects on the instrument's scintillator crystal. 
The NQ drill string (with a core bit attached) was removed from the borehole during the night of November 11 to allow for open hole logging with the electrical log and the BHTV the following morning.

The electrical log temperature was continuously monitored as the tool was lowered into the borehole. This tool was rated to $85^{\circ} \mathrm{C}$ but South West Exploration allowed it to be lowered to $100^{\circ} \mathrm{C}$. Unfortunately, this temperature also coincided with the depth at the bottom of the HQ drill string at $1143 \mathrm{~m}$ (3500 feet) and as such no open hole log information was obtained as the tool could not be further risked.

While entering the borehole, the BHTV temperature was also closely monitored as it has a rated maximum of $125^{\circ} \mathrm{C}$. Southwest exploration was contracted to provide only $304.8 \mathrm{~m}$ (1000 feet) of televiewer data with the primary target being the artesian fracture zone at $1750 \mathrm{~m}$. As such, logging began downwards at $1463 \mathrm{~m}\left(5200\right.$ feet). The BHTV, however, encountered a temperature of $130^{\circ} \mathrm{C}$ as well as a blockage at $1596 \mathrm{~m}$ (5237 feet). This blockage appears to correlate with some drilling difficulties as indicated in the drillers notes. At this point, it was decided that the logging could not continue to the bottom due to the high temperatures and the risk to the tool. The tool was returned to $1286 \mathrm{~m}$ (4220 feet) to $\log$ back down to $1463 \mathrm{~m}$ (5200 feet). Upon completion of this section, the televiewer was returned to the surface.

A weight was run on the rig's slickline to ensure the borehole was clear and to allow the DOSECC temperature tool to re-enter. A 'manual' logging procedure to obtain a continuous temperature profile was employed by recording by hand the slickline depth reading every 15 seconds as the temperature tool was pulled up. These DOSECC tool temperatures could then be reconciled to the slickline depth measurement by the relative times. The correction was effected by shifting the measured slickline depth to the known borehole TD. However, an appropriate correction factor for the slickline measurements to reconcile them with the true borehole depth is not known, it is expected that the depth values need to be shifted upwards.

The various temperature measurements made in the well are shown in the attached log plot (4.1.-2). These include measurements from the manual logging with the DOSECC tool, three different measurements on parts of the BHTV (motor, head, internal electronics), and the temperature from the electrical log.

Overall the data quality is quite good although not being able to reach the fracture zone is a setback. Briefly, there are numerous interesting correlations between the sonic, the earlier electrical log, and the neutron log. Further, the televiewer data is of very high quality and displays numerous fractures and stress related features that can be interpreted. The response of the televiewer is of further interest because the amplitude of the borehole reflections appears to correlate well with lithological changes in the rock. 


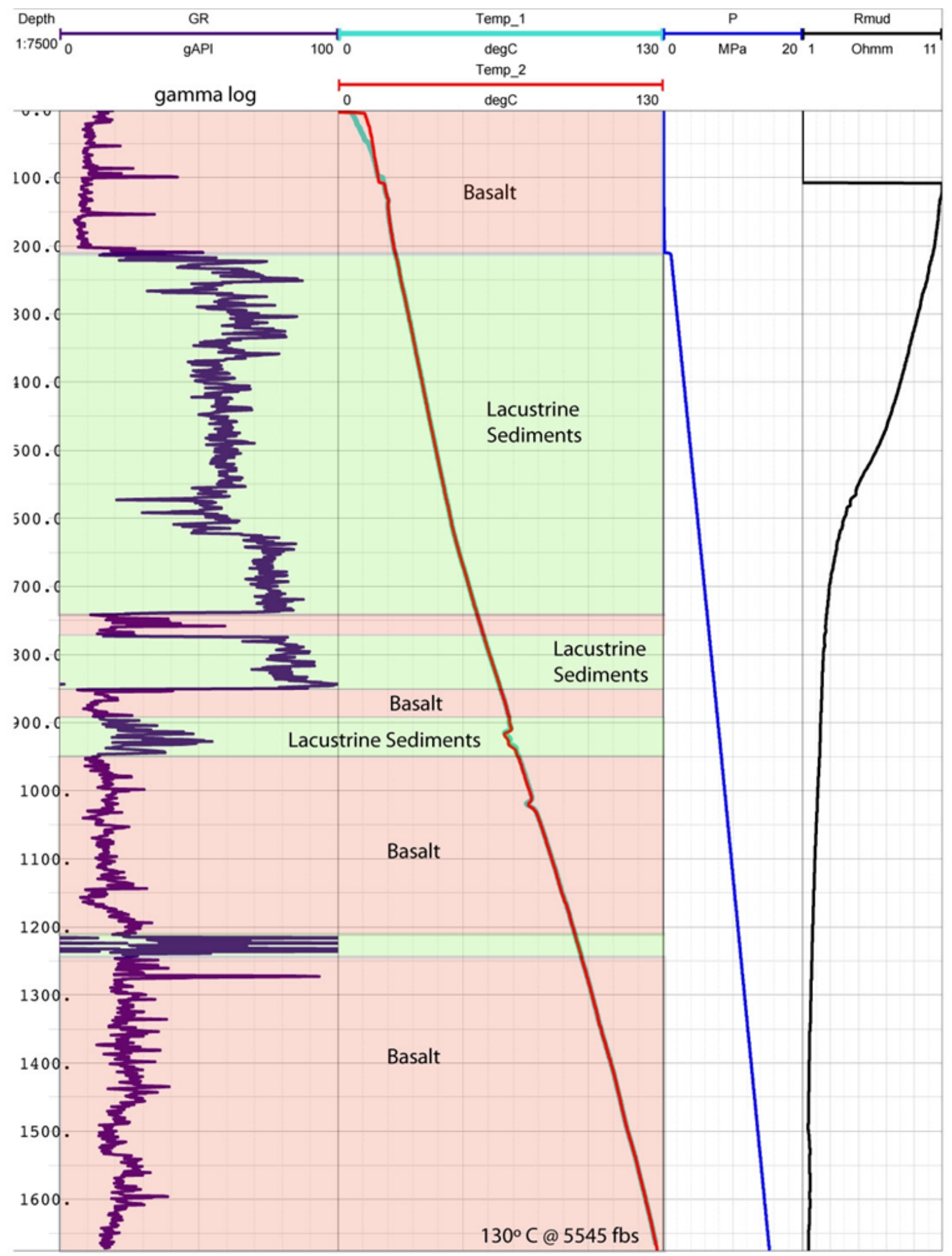

Figure 4.1-2. Geophysical results include measurements from the manual logging with the DOSECC tool, three different measurements on parts of the BHTV (motor, head, internal electronics), and the temperature from the electrical log. 


\subsection{Temperature Gradient}

\subsubsection{Overview}

Wire line coring offers a number of advantages over rotary drilling in the exploration for geothermal resources. It utilizes smaller rigs that can be operated at relatively low cost. Core samples can be analyzed for hydrothermal alteration and structural character. In addition, there is less thermal disturbance of the borehole compared to those drilled by rotary techniques.

Equilibrated temperature measurements are important for understanding the thermal regime encountered by a drill hole. However, temperature measurements during drilling can be very important in guiding an exploration drilling program. Our bottom-hole temperature measurements are based on the concept that slim-hole coring circulates lower fluid volume than rotary drilling, and the core stub at the bottom of the hole is the least thermally disturbed part of the hole. DOSECC designed a Bottom Hole Temperature Logger that is delivered to the bottom of the hole within the wire line core barrel. The temperature sensor extends out the bottom of the core barrel assembly and rests directly on the core stub. A temperature data logger records temperature as a function of time and is subsequently correlated with depth. The logger is allowed to remain in contact with the bottom hole for 20-30 minutes, and the resulting temperature build up curve is corrected using the $\mathrm{F}(\alpha, \tau)$ method (Harris and Chapman, 2007). We are using this correction to standardize the measurements at infinite time. However, the boreholes are not thermally equilibrated and retain the thermal impact of drilling. That is, permeable zones that have taken drilling fluid show up as negative excursions on temperature gradient plots.

The measurement of bottom-hole temperature during the drilling process also allows the operators to address permit and potential safety issues in real time. In addition, temperature data is available even if access to the hole is lost. As we will show in the subsequent discussion, temperature data from other sources has been used to verify the measurements made by the Bottom Hole Temperature Logger. We principally use temperatures measured by the Operational Support Group (OSG) of the International Continental Scientific Drilling Program (ICDP). Their measurements are from a temperature sensor (PT1000) located within their magnetic susceptibility sonde.

Figure 4.3-1 shows the bottom hole measurements recorded as the drilling progressed along with the corrected temperatures. During the coring, the temperature measurements show extensive lost circulation and formation cooling from about 850-1180 m. Mud returns were established at $1500 \mathrm{~m}$, but they were lost at $1745 \mathrm{~m}$ where artesian flow to the surface was also encountered. Our bottom hole temperature probe shows a corrected temperature of $149.4^{\circ} \mathrm{C}$ at $1,745 \mathrm{~m}$ and $1,772 \mathrm{~m}$. However, this temperature exceeds the limit of our probe, and the data was extrapolated from the buildup curve.

The history of geothermal investigations at Mountain Home Air Force Base is discussed in Armstrong et al. (2012). In 1986 a geothermal test well (MH-1) was drilled at Mountain Home AFB to a depth of 1,342 $\mathrm{m}$ (Lewis and Stone, 1988). $\mathrm{MH}-1$ had a maximum measured temperature of $93^{\circ} \mathrm{C}$ at 1,219 m. The Hotspot hole at Mountain Home AFB (MH-2) was spud on 9/1/11 and reached TD at $1,821 \mathrm{~m}$ on $1 / 31 / 12$. It is located $4.7 \mathrm{~km}$ to the northwest of $\mathrm{MH}-1$. The temperature depth measurements from $\mathrm{MH}-1$ are shown in Figure 4.3-1 and closely follow those from $\mathrm{MH}-2$.

\subsubsection{Mountain Home Thermal Logs}

MH-2 reached total depth of $1821.5 \mathrm{~m}$ on 2/4/12 and was subsequently cased to a depth of $1818.0 \mathrm{~m}$. Figure 4.3-1 shows the bottom hole measurements recorded as the drilling progressed along with the corrected temperatures. During the coring, mud returns were established at $1500 \mathrm{~m}$. They were subsequently lost at $1745 \mathrm{~m}$ where artesian flow to the surface was also encountered. The bottom hole temperature probe shows a corrected temperature of $149.4^{\circ} \mathrm{C}$ at $1,745 \mathrm{~m}$ and $1,772 \mathrm{~m}$. However, this temperature exceeds the limit of our probe, and the data was extrapolated from the buildup curve. 
Temperature profle of 1988 Mountaln Home AFB Geothermal Teet Well Compared to 2011-12 Geothermal TeotWell
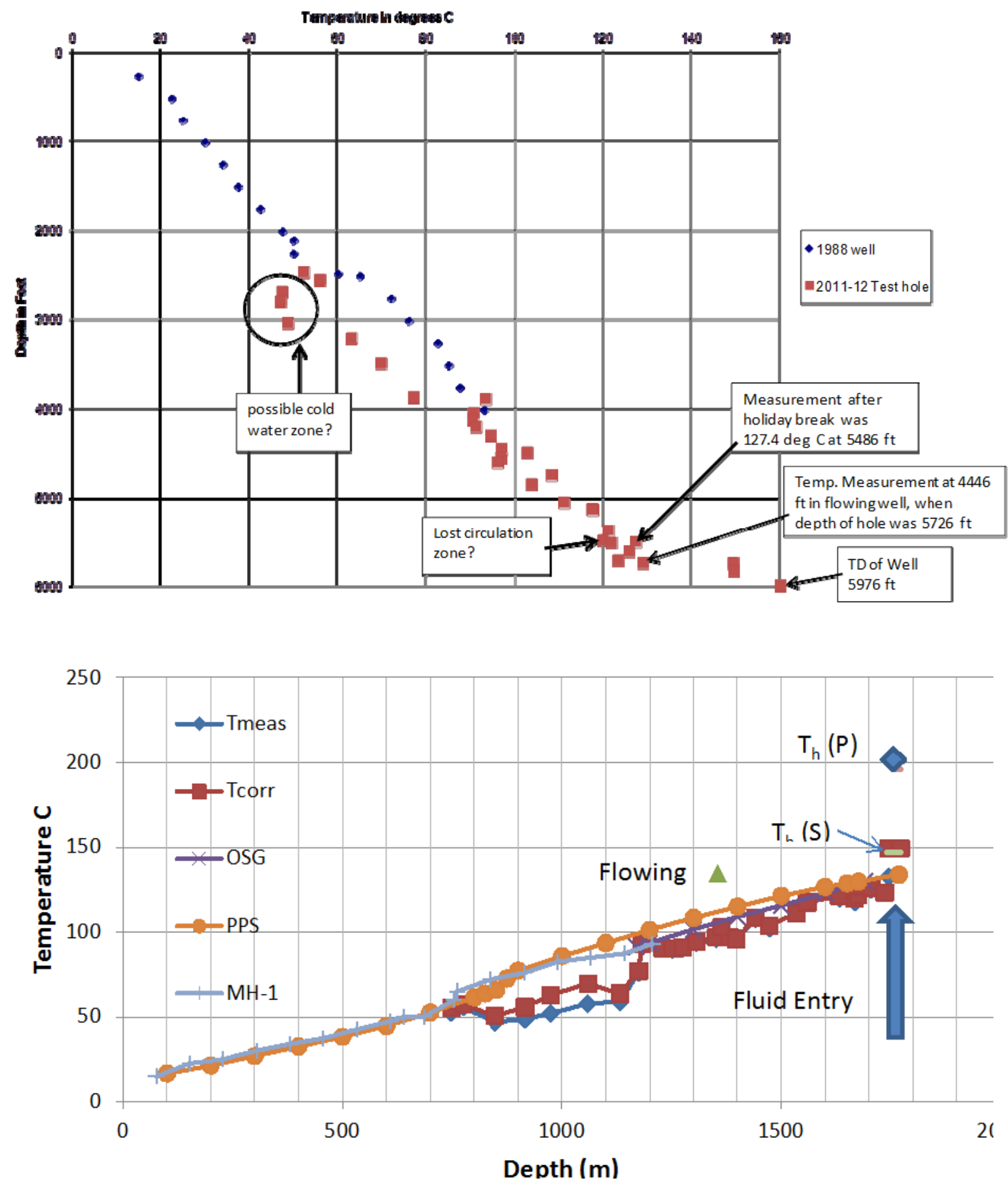

Figure 4.3-1. MH-2 thermal gradient log from BHTP compared to MH-1. 


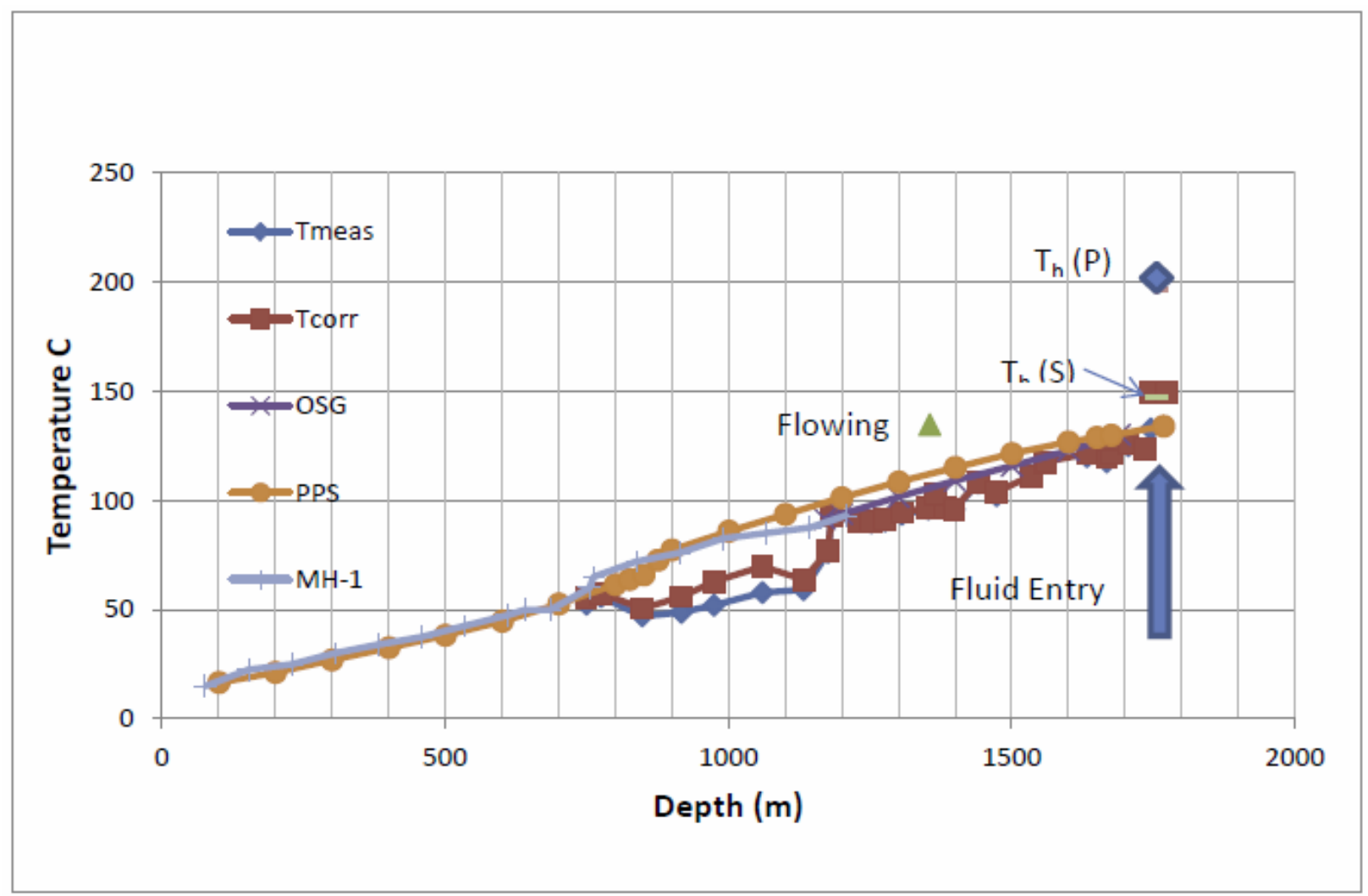

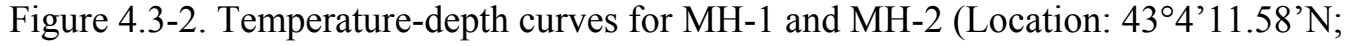
$\left.115^{\circ} 53^{\prime} 34.76^{\prime \prime} \mathrm{W}\right)$. Th $(\mathrm{P})$ and Th $(\mathrm{S})$ show primary and secondary fluid inclusion temperatures. The green triangle shows the temperature recorded in the hole while fluid was flowing to the surface. The location of the fluid entry at $1745 \mathrm{~m}$ is also shown.

While the well was flowing, a temperature probe was suspended in the hole at $1355.1 \mathrm{~m}$ and measured $134.6^{\circ} \mathrm{C}$. The flow at the surface through NQ pipe $(60.3 \mathrm{~mm}$ inner diameter) was estimated at 42 liters/minute $(11 \mathrm{gpm})$. In order to continue coring, the hole was treated with mud and lost circulation material that effectively stopped the artesian flow.

In April 2012, Pacific Process Systems, Inc. (PPS) recorded a continuous temperature and pressure survey in the 2-3/8" casing. These data have been corrected for ice point. The pressure data suggests the probe was hanging up in the casing below $1676 \mathrm{~m}$. When the depth is corrected for the hydrostatic pressure, it yields a maximum temperature of $133.9^{\circ} \mathrm{C}$ at $1768.1 \mathrm{~m}(5800 \mathrm{ft})$. With a thermal gradient of $\sim 75^{\circ} \mathrm{C} / \mathrm{km}$, this implies a bottom hole temperature of $138^{\circ} \mathrm{C}$ at $1821.5 \mathrm{~m}$ or a projected temperature of $\sim 151^{\circ} \mathrm{C}$ at $2 \mathrm{~km}$ depth.

The core from MH-2 is presently being logged in detail; however, a brief inspection shows some interesting features. We wanted to determine the character of the flow zone encountered at $1745 \mathrm{~m}$, but core recovery through this interval was poor and there is no clear indication of the character of the faults that cut the zone. In the course of this inspection, we identified hydrothermal breccias. These are typical jigsaw puzzle breccias whose voids have been partially filled by quartz + bladed calcite and include pyrite and chalcopyrite. A late filling of crystalline laumontite forms a coating but does not completely fill the voids. 
A preliminary fluid inclusion analysis by Dr. Joseph Moore on a sample of bladed calcite from $1756.5 \mathrm{~m}$ showed three populations. Two sets of primary inclusions showed $\mathrm{Th}=203^{\circ} \mathrm{C}$ and $2.7 \%$ $\mathrm{NaCleq}$ and $\mathrm{Th}=1960 \mathrm{C}$ and $4.2 \%$. A set of secondary inclusions measured $\mathrm{Th}=147^{\circ} \mathrm{C}$ and $1 \% \mathrm{NaCleq}$ (see Figure 5.2-1). The secondary inclusion homogenization temperature is very close to the temperature while coring measurement of $149.4^{\circ} \mathrm{C}$.

Hydrothermal brecciation indicates that P-T conditions were along the boiling point curve (BPC). Therefore, we envision conditions that assume the depth is as observed and the hydrostatic is controlled by the present land surface elevation. This suggests temperatures of about $340^{\circ} \mathrm{C}$ with cooling to the present observed $134-150^{\circ} \mathrm{C}$. These temperatures are similar to current production temperatures at the Raft River geothermal system (Jones et al., 2011).

The temperatures measured in $\mathrm{MH}-2$, the presence of fracture permeability and hydrothermal brecciation, and the apparent size of the geothermal system( $4.7 \mathrm{~km}$ strike length to $\mathrm{MH}-1)$ implies that the system has a magmatic association. It is also important to state that the coring has just intersected the top of the geothermal zone. The lateral extent, depth and reservoir temperature has not been fully determined. The region around this site represents a prime target for further exploration.

\subsection{Water Chemistry and Geothermometers}

Drilling encountered an artesian geothermal system at 5726 feet. This system flowed at 11-18 gallons/minute and was allowed to flow for about 12 hours before sampling. Field measurements of electrical conductivity $(870 \mu \mathrm{S}), \mathrm{pH}(9.59)$, and alkalinity $(100 \mathrm{mg} / \mathrm{L})$ were made, and samples were taken by the project hydrologist for major ions as well as hydrogen and oxygen isotopes. Sample analyses were completed at the USU Analytical Laboratory and the Thermochem, Inc., (Santa Rosa, California) analytical laboratory.

The high $\mathrm{pH}$ (9.59) and high sulfate $(477 \mathrm{mg} / \mathrm{L})$ suggest that the water is at equilibrium with the altered basalt at the measured temperature (see Figure 5.3-1). Deuterium (-88 per mil) and oxygen-18 $(-3.2$ per mil) levels suggest that the water is old, is not meteoric, and/or has undergone significant fractionation (see Figure 4.4-1) (Lachmar et al 2012).

Temperature readings with the BHT tool indicated temperatures $\sim 150^{\circ} \mathrm{C}$ at that time; later temperature logging indicates temperatures of $\sim 135-140^{\circ} \mathrm{C}$, possibly as the result of downward flow of cold water. Chemical analysis of the water - which was completely free of contamination by drilling muds after 12 hours of flow - indicates equilibrium temperatures of $\sim 140-150^{\circ} \mathrm{C}$ (see Table D-2.1.4-1).

The calculated equilibrium temperatures are consistent with both the preliminary fluid inclusion in calcite studies indicating temperatures of $\sim 150^{\circ} \mathrm{C}$ and $\sim 195^{\circ} \mathrm{C}$ (Moore, personal communication 2012), and with alteration mineral assemblages that include chlorite and laumontite (Nielson et al 2012; Lachmar et al 2012).

The artesian flow was killed with weighted mud to allow continued drilling, so a flow test was not possible. 
A.

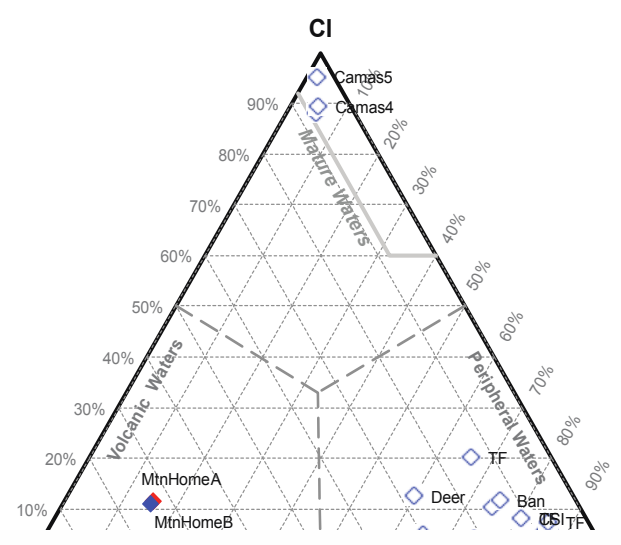

B.

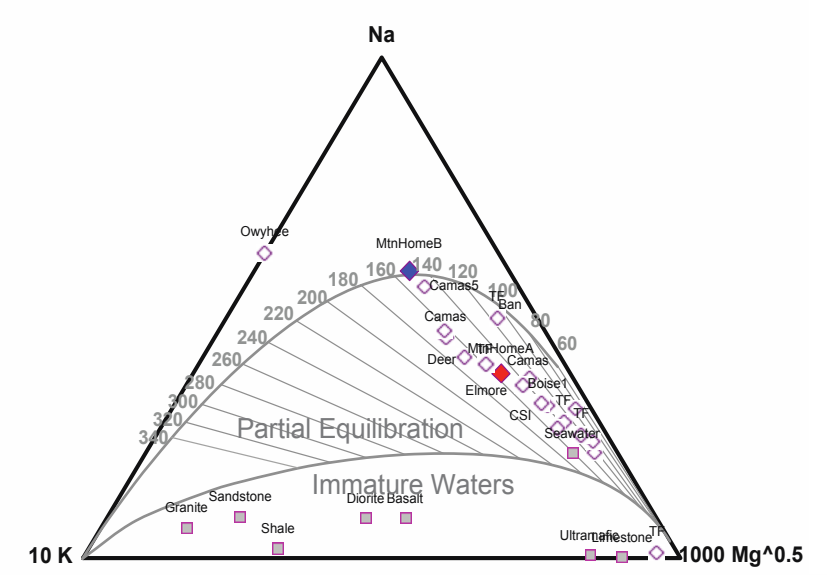

C.

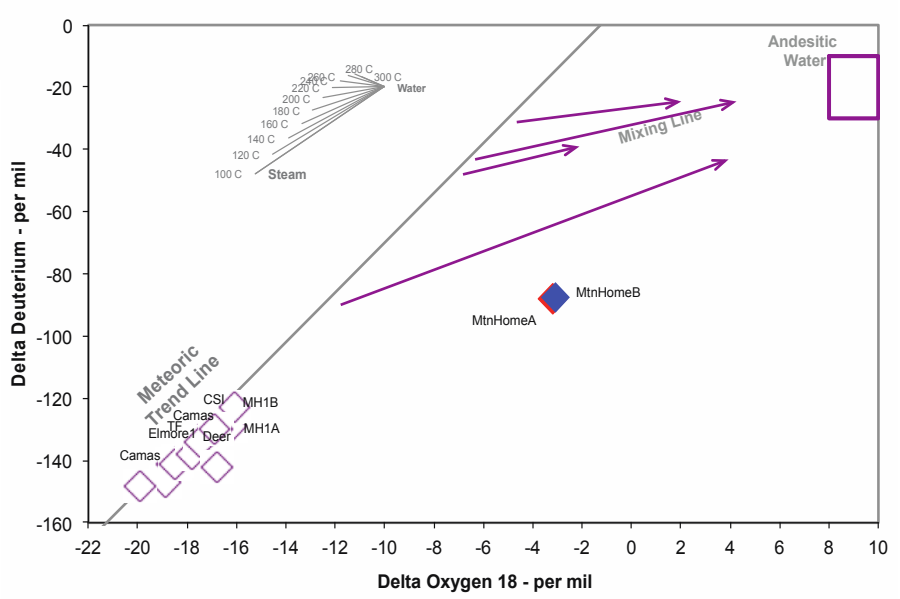

Figure 4.4-1. Chemistry of artesian geothermal water from MH-2B. (A) Sulfate-Chlorine-bicarbonate ternary. MH-2 waters are relatively rich in sulphate, suggesting equilibration with mafic volcanic rocks; all other southern Idaho thermal waters are bicarbonate rich, except for two springs near Camas. (B) $\mathrm{Na}-\mathrm{K}-\mathrm{Mg}$ ternary. MH-2 waters are partially to fully equilibrated with equilibrium temperatures of $150-160^{\circ} \mathrm{C}$. (C) Plot of $\partial 18 \mathrm{O}$ vs $\partial \mathrm{D}$. MH-2 geothermal waters fall on mixing line between meteoric water and volcanic water; all other southern Idaho thermal waters fall on the meteoric trend line. These data indicate that the MH geothermal system is distinct from other thermal systems in Idaho, which represent meteoric water that has been heated by deep circulation on faults. 


\subsection{Comparison of MH Geothermal System to Raft River Site}

Geothermal gradients in the Mountain Home Geothermal System (MHGS) range from $59^{\circ} \mathrm{C} / \mathrm{km}$ (Bostic $1 \mathrm{~A}$ ) to $75^{\circ} \mathrm{C} / \mathrm{km}(\mathrm{MH}-2)$, with temperatures of $135-150^{\circ} \mathrm{C}$ measured at $1745 \mathrm{~m}$ depth in $\mathrm{MH}-2 \mathrm{~B}$. As noted above, these temperatures are similar to current production temperatures at the Raft River geothermal site. Raft River is a classic Basin-and-Range style geothermal resource, associated with deep range front faults covered in part by alluvial fan deposits that provide a thick if somewhat porous insulation. In contrast, the MHGS is distinct from Basin-and-Range style deposits in that it is not associated with a range front fault system, and it is insulated by a thick $(\sim 700 \mathrm{~m})$ interval of very fine grained lacustrine sediments and a further section $(\sim 750 \mathrm{~m})$ of highly altered basalt and basaltic sediments. The similar temperatures to Raft River and the occurrence of artesian hydrothermal flow strongly suggest a viable resource for power development.

\section{CONCEPTUAL MODEL}

\subsection{Introduction}

The geothermal system discovered at Mountain Home AFB lies within the Snake River Plain volcanic province, which is generally thought to represent the track of the Yellowstone hotspot - a deep-seated mantle plume which has remained relatively fixed in space as the North American plate moved to the SW (Smith et al 2009). It also lies north of the Basin and Range province, which hosts active geothermal systems in northern Nevada and south-central Utah. However, the western Snake River Plain, where Mountain Home is found, does not sit on presumed plume track (as represented by the Snake River Plain and the absolute motion vector for North America), and it is distinct from the Basin and Range in its structures and location.

Active geothermal systems are generally thought to form in one of two settings: (1) over young, shallow felsic plutons that provide a long-term heat source (e.g., The Geysers and Salton Trough, California), or (2) along deep-seated range front faults that tap fluid circulation from deep in the crust (Raft River, Idaho, and Dixie Valley, Nevada). Neither of these settings appear to apply to the western SRP or Mountain Home: (1) there are no young felsic volcanic rocks exposed in the Snake River Plain west of Big Southern Butte (near Idaho Falls, Idaho), rather, all of the felsic volcanic rocks are $>9$ Ma in age - too old to represent a viable heat source for active geothermal systems; (2) the Mountain Home geothermal system is not associated with the range front fault system; it sits some $30 \mathrm{~km}$ south of the range front faults to the north, and even farther from range front faults to the south. Its location near the center of the basin is not consistent with a Basin and Range-type model, although it does appear to mark the location of buried faults systems.

The western SRP near Mountain Home hosts a basaltic volcanic system with eruptions as young as $200 \mathrm{ka}$, and potentially even younger. Basaltic terrains are generally not appreciated as hosts for high-temperature geothermal systems. Smith and Shaw (1975) remarked on the idea that basalt is channeled to the surface through fractures and does not form high-level magma chambers, whereas rhyolitic magmas commonly form chambers in the shallow crust and are therefore more capable of providing a long-lived heat source for hydrothermal circulation. The question becomes: how do we account for an active geothermal system in a basaltic volcanic province that lacks shallow felsic intrusions and basin and range-type structural controls? 


\subsection{Observations}

There are a number of observations which suggest that the western SRP system requires a new conceptual model for geothermal activity, and that this model may be used to further exploration for new resources within this region, and perhaps others. The basic observations listed above are: (1) the lack of young felsic volcanism anywhere in the western SRP; (2) the occurrence of the Mountain Home AFB resource near the axis of the western SRP graben, far from the range front faults, and (3) the occurrence of young basaltic volcanism throughout the region, with vents as young as $200 \mathrm{ka}$ or less (Shervais et al 2002; White et al 2002; Shervais and Vetter, 2009).

Additional observations include:

(4) Documentation of a mafic sill or sill complex in the mid-crustal region beneath both the eastern and western SRP by seismic methods (e.g., Pakiser and Hill, 1967; Peng and Humphries, 1997).

(5) Geochemical evidence for a layered mafic sill complex beneath both the eastern and western SRP, based on fractionation-recharge cycles in basalt flows sampled as drill core (Shervais et al., 2006).

(6) The Graveyard Point Sill, exposed near the southern margin of the western SRP, documents a single layered basaltic sill up to $160 \mathrm{~m}$ thick (White, 2009); this confirms the existence of such sills inferred from seismic data and lava chemistry.

(7) High-resolution gravity mapping by the USGS confirms the presence of an $\sim$ EW trending gravity high that lies at an oblique angle to the axis of the WSRP; this gravity high has been interpreted as a horst block, and may be cored by a mafic sill complex (Shervais et al., 2002; 2013). The alignment of this gravity high is approximately parallel to a fault system mapped north of Mountain Home, which lies at an oblique angle to the range front fault system (Shervais et al., 2002).

(8) Water chemistry, isotope chemistry, and fluid inclusion data support relatively high fluid temperatures $\left(140-195^{\circ} \mathrm{C}\right)$, and geothermal water that is in equilibrium with mafic volcanic rocks. Note that the $\mathrm{MH}$ artesian geothermal waters are the only geothermal waters that do NOT sit on the meteoric fractionation line in D-O isotope space.

(9) The Mountain Home geothermal system is currently active, although it was formerly at higher temperatures.

These observations require a basalt-driven system that is both long-lived and hot, and which is tapped by a stress field that is oblique to the stress responsible for the range front faults and opening of the WSRP graben.

\subsection{MHGS Conceptual Model}

We propose that the Mountain Home Geothermal System (MHGS) derives its enthalpy from a layered basaltic sill complex in the middle to upper crust. Unlike basalt-driven systems in Iceland and Hawaii, which are associated with relatively short-lived basaltic dikes that cool quickly, the SRP basaltic sill complex is long-lived because (a) each individual sill is $\sim 100-200 \mathrm{~m}$ thick, and (b) the intrusion of multiple sills into the same level of crust pre-heats this crust, minimizing heat loss from subsequent intrusions. It has long been known that basaltic sills tend to pond at levels of neutral buoyancy, and that subsequent sills will cluster near this level, at or just above previously intruded sills.

Conduits for heated fluids are provided by faults that trend essentially parallel to the long axis of the gravity high, which is interpreted to represent an uplifted horst block. The location and orientation of these faults are thought to be controlled by the distribution of sill complex within the crust: crust modified by sill complex intrusion will tend to act as a rigid block during strain, localizing strain along its margins. Because the horst block lies near the axis of the WSRP, these conduits conduct fluid upwards far from the range front system. 


\subsection{Implications for Exploration Strategies in Southern Idaho}

The implications of this new conceptual model for geothermal resource exploration in the southern Idaho/SRP region are significant, because this model differs greatly from models that have proved successful elsewhere.

First, the highest heat flux appears to occur along or near the central axis of the SRP (Shervais et al., 2011). This is consistent with a heat source that is thickest near the axis, and thinner towards the margins. Further, the long-lived nature of this heat flux, and its continued flux long after the active plume has moved to the NE (relative to the lithosphere), requires the slow release of heat from a cooling pluton, or in this case, sill complex representing multiple intrusions of basaltic melt. Second, the dominance of a nearly EW gravity high (horst block) beneath the WSRP, which appears to be bordered by a younger set of similarly oriented faults, implies that water heated by this source may be conducted into the upper crust by the boundary faults near the valley axis - and not along its margins.

If our model is correct, then geothermal resource exploration in the WSRP should focus on locations which are far from the range fronts faults, and that are also located over the steep gravity gradients that mark the margins of the gravity high/horst block. The dominant exploration tool will likely be high-resolution gravity mapping, coupled with resource confirmation by a program of slim hole drilling and coring. 


\section{ECONOMIC ANALYSIS \\ 6.1 Approach}

An analysis was performed to assess the power generation costs from a resource that was postulated based on the Mountain Home Air Force Base Well \#2. This analysis was performed using the US DOE's Geothermal Electricity Technology Evaluation Model, or GETEM. This model was developed for the DOE Geothermal Technologies Office to estimate representative power generation costs from geothermal energy. Though intended to provide a more generic assessment of power generation costs, it can be used to make a preliminary assessment of generation costs at a specific site.

The model estimates capital and operating costs based on the input provided to define a specific scenario. The scenario defined for the Mountain Home resource was based on the following assumptions which were inputs to the model:

Resource-Based on the exploratory well drilled, a resource is expected at a depth of $6,250 \mathrm{ft}$ that would have a fluid temperature of $155^{\circ} \mathrm{C}$.

Project Basis-At the expected resource temperature it is probable that a binary power plant would be utilized. For this conversions system, GETEM assumes that the plant will be air-cooled. For the evaluation, it is assumed that the resource will have 4 producing wells; each having a flow rate of $1,250 \mathrm{gpm}$. This flow approximates that from geothermal wells at similar depths in Idaho. It is assumed that the project would operate for 30 years.

Exploration-The exploration costs that are estimated by the model are those costs incurred in finding a potential resource. For the Mountain Home scenario, it is assumed that one well is drilled at a cost of $\$ 831 \mathrm{~K}$, with $\$ 50 \mathrm{~K}$ allotted for activities not directly associated with drilling. This cost is low relative to what one might expect to encounter geothermal exploration, as a number of the sites that are explored do not produce an indication of a potential resource.

For the Mountain Home scenario, it is assumed that the exploration phase takes $\sim 1.5$ year with a discount rate (cost of money) of $30 \%$ applied to the costs incurred during this phase.

Confirmation-The costs that are estimated for the confirmation phase of a project development are for those activities needed to confirm the commercial potential of the resource. This typically requires drilling multiple wells that demonstrate the ability for the resource to provide some fraction of the total production capacity needed for the project. As with the exploration phase, in typical geothermal developments, not all locations that have a potential resource will be able to demonstrate commercial potential.

For the Mountain Home scenario, it is assumed that it will be able to demonstrate the necessary commercial potential. This will be done by drilling 2 successful production wells that will demonstrate half the total production capacity. Because not all wells drilled will necessarily be successful, a drilling success rate of $60 \%$ is used. The cost for each well drilled during this phase is $\$ 3,390 \mathrm{~K}$ per well. This value is $\sim 20 \%$ higher than the costs drilled when the well field is completed. The higher cost is used to reflect the effect of a learning curve when drilling multiple wells within a given field.

The confirmation phase at Mountain Home was assumed to take 1.5 year with a discount rate of $30 \%$ applied to costs incurred during this phase. The expectation is that once the commercial potential of the resource is shown, that the developer will be able to secure the funds to complete the project at lower discount rates. 
Well Field Completion-Once the commercial potential of the resource is confirmed and funds secured to complete the project, the well field will be drilled out. During this phase a drilling success rate of $80 \%$ is assumed. To complete the well field, the remaining 2 production wells are drilled along with 2.7 injection wells and 0.9 unsuccessful wells. The capital costs for this phase are based on a cost of $\$ 3,325 \mathrm{~K}$ for each well drilled. A cost of $\$ 200 \mathrm{~K}$ per successful production and injection well is included in the capital cost estimate for the surface piping and equipment between the well and the power plant. A duration of 1.5 years is allowed to complete the field, with a discount rate of $15 \%$ applied to the costs incurred during this project phase.

Geothermal Pumping-The model calculates the geothermal pumping power needed based on a well configuration, the flow rate per well, well depth and fluid temperature, and a productivity/injectivity index defined by the user. For Mountain Home, a productivity index of $2,500 \mathrm{lb} / \mathrm{hr}$ per psi, or $\sim 5.5 \mathrm{gpm}$ per psi was assumed. The injectivity index was assumed to be the same as the productivity index. The estimated geothermal pumping power for both production and injection was slightly less than 1.4 MW electrical.

Power Plant-The model sizes the binary power plant based on the total flow from the production wells. Correlations are embedded in the model that relate the cost of the power plant to the amount of 'net' power that is produced from a given flow rate - plants that produce more power cost more. A trade-off is performed between the plant cost and the amount of power produced until the generation cost is minimized (effectively the total capital project cost in terms of $\$ / \mathrm{kW}$ is at a minimum as well). The relationship between cost and performance assumes that each plant is custom built for the specific site and application. If a user has a cost and level of performance for a specific plant, those values can be input to the model and used in estimating the generation costs.

The power plant construction is assumed to occur in parallel with the completion of the well field, with 1.5 years to design and construct. A discount rate of $7 \%$ is used for this project phase; this value is lower than that assigned to completing the well field because there is assumed to be less risk associated with the plant than with drilling the wells. For Mountain Home, it was assumed that 0.5 mile of transmission line would be needed and its cost is included in the total project capital cost.

The optimal plant size the model estimated was $14.5 \mathrm{MW}$. After deducting the geothermal pumping power requirements, the project would produce $\sim 13.1 \mathrm{MW}$ of power for sale. The estimated cost of the plant (including transmission) is $\sim \$ 45.2 \mathrm{M}$, or $\sim \$ 3,115$ per $\mathrm{kW}$.

Operating and Maintenance Costs-The maintenance cost portion of the annual operating and maintenance costs (O\&M) are determined as a \% of the capital cost estimates (typically 1-2\%). The model estimates maintenance costs for the geothermal production pumps based on pump size and setting depth. Operation costs are based on the plant size and the type of plant. The model also includes estimates for royalties, and taxes and insurance. For the Mountain Home scenario, it is assumed that there are no royalties. For the Mountain Home scenario evaluated the annual O\&M costs are estimated to be $\sim \$ 2.96 \mathrm{M}$.

Other-The estimated generation cost for the Mountain Home scenario assumes that the utilization factor for the plant during the first year of operation is $95 \%$ - this means the plant MW-hr of power produced would be $95 \%$ of what would be produced if the plant operated at the design output for the entire year $(8,760 \mathrm{hrs})$. This factor takes into account both the effect of the varying ambient temperature throughout the year as well as the down time for maintenance. For Mountain home it is assumed that the resource temperature declines at a rate of $\sim 0.5^{\circ} \mathrm{C}$ per year. The effect of this declining temperature on power production is estimated and included in determining the generation costs.

The estimated generation costs include a $15 \%$ contingency for all capital costs, a 5 year MCRS depreciation schedule, and does not include the impact of any renewable incentives. 


\subsection{Estimated Costs}

Table 6.2-1 summarizes the estimated capital costs, operating costs, and power output for the potential Mountain Home project based on the approach and assumptions described. Those costs are shown in the 2 nd column ( 1 st column of values).

Table 6.2-1. Estimated costs for the potential Mountain Home AFB geothermal project.

\begin{tabular}{|l|l|l|l|}
\hline \multicolumn{1}{|c|}{ Number of Wells } & \multicolumn{1}{c|}{4} & \multicolumn{1}{c|}{4} & \multicolumn{1}{c|}{3} \\
\hline Cost per Well & $\$ 3,325 \mathrm{~K}$ & $\$ 2,500 \mathrm{~K}$ & $\$ 2,500 \mathrm{~K}$ \\
\hline Flow per Well & $1,250 \mathrm{gpm}$ & $1,250 \mathrm{gpm}$ & $1,667 \mathrm{gpm}$ \\
\hline Total Flow to Plant & $5,000 \mathrm{gpm}$ & $5,000 \mathrm{gpm}$ & $5,000 \mathrm{gpm}$ \\
\hline Power & & & \\
\hline Plant,net & $14,504 \mathrm{~kW}$ & $14,190 \mathrm{~kW}$ & $13,897 \mathrm{~kW}$ \\
\hline Sales & $13,129 \mathrm{~kW}$ & $12,812 \mathrm{~kW}$ & $11,863 \mathrm{~kW}$ \\
\hline Capital Costs (with contingency) & & & \\
\hline Exploration & $\$ 956 \mathrm{~K}$ & $\$ 719 \mathrm{~K}$ & $\$ 719 \mathrm{~K}$ \\
\hline Confirmation & $\$ 16,232 \mathrm{~K}$ & $\$ 12,248 \mathrm{~K}$ & $\$ 12,248 \mathrm{~K}$ \\
\hline Well Field Completion & $\$ 26,323 \mathrm{~K}$ & $\$ 20,733 \mathrm{~K}$ & $\$ 14,504 \mathrm{~K}$ \\
\hline Power Plant & $\$ 51,937 \mathrm{~K}$ & $\$ 47,193 \mathrm{~K}$ & $\$ 46,863 \mathrm{~K}$ \\
\hline Permitting & $\$ 288 \mathrm{~K}$ & $\$ 288 \mathrm{~K}$ & $\$ 288 \mathrm{~K}$ \\
\hline Total Capital Costs & $\$ 95,736 \mathrm{~K}$ & $\$ 81,180 \mathrm{~K}$ & $\$ 74,619 \mathrm{~K}$ \\
\hline Annual O\&M Costs & $\$ 2,962 \mathrm{~K}$ & $\$ 2,689 \mathrm{~K}$ & $\$ 2,576 \mathrm{~K}$ \\
\hline Generation Costs & $12.73 \mathbb{C} / \mathrm{kW}-\mathrm{hr}$ & $11.44 \mathbb{C} / \mathrm{kW}-\mathrm{hr}$ & $11.31 \mathrm{C} / \mathrm{kW}-\mathrm{hr}$ \\
\hline
\end{tabular}

Two other possible scenarios are given in the last two columns. These scenarios are based on the well costs being $\sim 25 \%$ lower and the effect of increasing the flow per well and reducing the number of wells required to produce the same flow rate to the power plant. Note that the power output from the plant differs for the 3 scenarios even though the flow rate is constant. This is the effect of the model varying the plant performance and cost to produce the minimum generation cost. For the 3rd scenario, the geothermal pumping power increases by $\sim 50 \%$ because of the increased flow per well. This decrease in sales is offset by the reduced well field costs. The net effect is a small reduction in the generation cost.

\subsection{Summary of Economic Assessment}

A preliminary evaluation of the potential generation cost at Mountain Home suggests that this cost would be between 11 and 13 cents per $\mathrm{kW}$-hr, provided the assumptions made were realized. Because the model produces generic estimates for costs of power and the considerable uncertainty in the costs associated with finding and developing a commercial resource, it is probable that the actual costs could be 2 to 4 cents higher or lower than this estimate. Also this estimate does not include the effect of any federal or state incentives for renewable power production, which would lower the generation cost. 
If the project were to proceed, the generation costs will be greatly dependent upon the resource that is found. Important resource characteristics that will impact the generation costs include its temperature and productivity. Higher temperatures allow more power to be produced from the well field, while increased productivity will allow the geothermal pumping power to be decreased or more flow produced for a given level of pumping power. For the defined Mountain Home scenario, if the fluid temperature ended up at $170^{\circ} \mathrm{C}$ with no change in productivity, the estimated sales would increase to $\sim 15 \mathrm{MW}$ with a generation cost of $\sim 10.8$ cents per $\mathrm{kW}-\mathrm{hr}$. Conversely if the temperature decreased to $140^{\circ} \mathrm{C}$, the sales would decrease to $\sim 10.9 \mathrm{MW}$ and the generation cost would increase to $\sim 15.7$ cents. For the scenario defined for Mountain Home, reducing the Productivity/Injectivity Index by $50 \%$ would lower the generation cost to 11.7 cents, while doubling the value would increase the generation cost to 15.1 cents. The temperature and resource productivity are parameters that are inherent to the resource; their definition is critical to the confirmation phase, which would be the next step in developing the Mountain Home resource. 


\section{RECOMMENDATIONS}

The data presented in this report show that a viable electric-grade geothermal resource prospect exists beneath Mountain Home Air Force Base. The economic analysis shows that the projected cost of electricity derived from this resource is comparable to other geothermal developments. This is higher than the current cost of electricity from natural gas - which is itself subject to future uncertainties related to the future availability and demand for natural gas. The projected costs for geothermal power do not include a "security differential" or the value of energy independence for the base.

The recommendations made here are structured to account for a range of possible outcomes, dependent in part on the availability of a willing commercial partner:

1. Development of the MHAFB geothermal resource in partnership with a private geothermal developer - This would consist of drilling at least one, and more likely several, production wells and injection wells as outlined in the Economic Analysis section of this report. This development would be contracted through a Power Purchase Agreement (PPA) or other contractual arrangement between the USAF and the developer. The contractual mechanism for this arrangement is yet to be defined. The developer would assume most of the financial risk, which will be significant given the cost of drilling production wells and the limited knowledge of the geothermal reservoir now available.

2. The USAF could partner with a commercial geothermal developer to drill additional exploratory slim holes to further characterize the geothermal resource beneath the base Since slim hole exploration wells cost $20-25 \%$ of a single production well this option minimizes the initial risk for the developer. After drilling one or more slim holes to prove out the resource, the developer could then decide whether or not to initiate development of a production well, as outlined in option 1 above.

3. The USAF could fund continued study of this resource through research collaboration, similar to the approach taken in the MH-2 effort. This collaborative approach would leverage research dollars and provide the Air Force access to advanced research capabilities from academics and the Idaho National Laboratory at discounted costs. This effort would focus on additional slim hole exploration wells, along with surface geophysical studies to further characterize the basement structure and distribution of faults at depth that could act as fluid conduits - To make the Mountain Home Geothermal Prospect more attractive to a commercial partner, the uncertainty regarding the geothermal reservoir could be reduced by the Air Force partnering with a research team interested in answering scientific questions regarding the SRP geology and hydrogeology. If matching research dollars could be offered by the Air Force, it would greatly increase the chances for additional matching or greatly leveraged funding from DOE and other sources. In order for this effort to be successful, it is recommended that the Air Force continue to fund a low level, but sustained effort to keep the academic partners engaged and actively seeking external funding. The funding level required is estimated at $\$ 25,000$ per year and it could be channeled through the Center for Advanced Energy Science in Idaho Falls, which is a consortium of Idaho Universities in partnership with the INL. These funds could also be used to maintain the Utah State University led Hotspot Project Team. Through this effort, the Air Force could also reach out to China Lake and build a relationship with their geothermal exploration and development team. For planning purposes, it is recommended that the research collaboration effort include one to two new slim hole wells designed for maximum efficiency. For instance, the wells would be drilled using a rotary system for the upper kilometer (through the lakebed sediments) and wireline coring below. This approach allows drilling to continue under lost circulation conditions, and retrieve core samples that can be studied to further characterize the resource and its reservoir. This may require a slightly larger rig than the CS-4002 used for $\mathrm{MH}-2$, but could also be drilled by combining a rotary or air rotary rig for the upper 2000-3000 feet and continuing with a CS-4002 class rig for the deeper wireline drilling. With a careful design, having a larger upper hole diameter, it might be possible to perform a pumping 
test of the corehole(s) or perform an artesian flow test to better constrain the permeability of the Mountain Home geothermal resource.

The USAF has been pursuing options 1 or 2 to determine the level of interest by commercial geothermal developers. There is a level of interest by the commercial sector, but a developer has not yet been found on terms suitable to the USAF. It is recommended that the USAF continue to seek a commercial partner, however, currently it appears that the USAF may need to fund further exploration efforts in order to reduce risk for potential commercial partners, and to secure the best possible terms in any development agreement. Therefore, it is strongly recommended that the Air Force remain engaged with the team built up for this effort and that the Air Force has at its disposal access to academic geothermal experts in the region for preparing proposal for additional research and development using option 3.

If further exploratory work is deemed advisable, it is recommended that this work include the following:

1. High-resolution gravity surveys to further constraint the subsurface structure - It is recommended that the USAF contract this work through the US Geological Survey, which has already carried out similar studies around Mountain Home as part of Project Hotspot. An example of this work is seen in Figure 1.0-2.

2. Development of one to three additional slim hole exploration wells - These wells would be sited using data from the high-resolution gravity mapping and existing seismic data. Each well should be designed and funded for a minimum depth of $2 \mathrm{~km}$ (6600 feet) in order to penetrate the top of the known geothermal resource (at $1.75 \mathrm{~km} / 5926$ feet) and continue far enough into the resource to characterize the optimal depth for future production and injection wells. Also, to the extent practical, either a pumping test or flow test should be factored into the design of the additional slim holes.

3. Development of new slim hole with rotary or air rotary drilling system to 800-1000 m depth (2500-3000 feet) with wireline coring below - This recommendation is based on the known thickness of the overlying sediments (which should be cased off prior to wireline coring) and the fact that wireline coring can proceed during lost circulation at depth (circulation was not lost in the sediments in $\mathrm{MH}-2$; lost circulation must be cured before continuing if it occurs during rotary drilling).

4. Studies of the secondary mineralogy of the recovered core should be funded to document the temperature environment of the samples - This would include clay mineralogy, other secondary mineral assemblages (e.g., zeolites), and a study of fluid inclusions in secondary calcite and quartz).

The projected costs for a slim hole exploration well is approximately $\$ 1.0 \mathrm{M}$ to $\$ 1.2 \mathrm{M}$ for a 6000 foot deep hole, based on actual costs in 2010-2012 (see Figure 7.0-1). This compares favorably with a projected cost of $\$ 4.1 \mathrm{M}$ for a 6000 foot production well in 2010 . Costs are expected to rise as economic recovery occurs, but these cost increases would likely be a consistent percentage increase for both production and slim holes, making the actual cost increase for a production well $4 \mathrm{x}$ higher than the actual cost increase on a slim hole. 


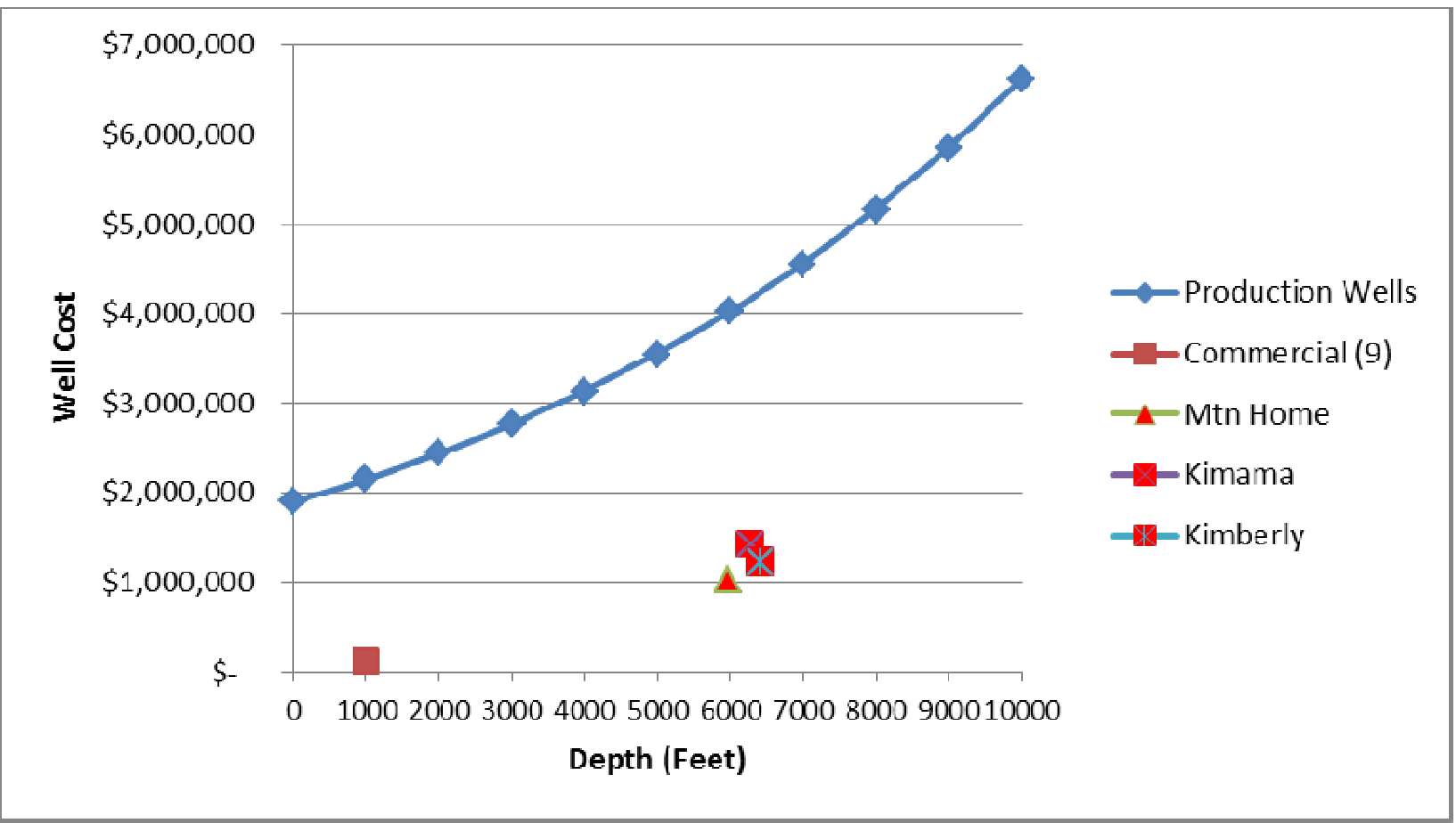

Figure 7.0-1. Drilling costs for production well vs. for slim hole well in 2010 dollars. 


\section{REFERENCES}

Blackett, R. E., and S. I. Wakefield, 2002, Geothermal Resources of Utah: A Digital Atlas of Utah's Geothermal Resources, Utah Geological Survey.

Blackett, R.E., Sowards, G.M., and Trimmer, E., 2004, Utah's High Temperature Geothermal Resource Potential - Analysis of Selected Sites, Utah Geological Survey.

Blackwell, D.D., 2007, "Summary of DOE Geoscience Studies of the Dixie Valley Geothermal System," Stanford University Geothermal Workshop, Stanford University, Stanford, California, January 30-February 1, 2007.

Breckenridge, RP, Shervais, JW, Nielson, DE, Wood, TR, 2012, Exploration and Recourse Assessment at Mountain Home Air Force Base, Idaho Using an Integrated Team Approach. Geothermal Resources Council Trans, v36, 615-619.

Coolbaugh, M., et al., 2005, Geothermal Potential Map of the Great Basin Region, Western United States, Nevada Bureau of Mines and Geology, Map 151. Available at: http://www.unr.edu/geothermal/published_maps.htm.

Delahunty, C., Nielson, DL, and Shervais, JW, 2012, Coring of Three Deep Geothermal Holes, Snake River Plain, Idaho. Geothermal Resources Council Trans., v36, 641-647.

Lachmar, TL, Freeman, T., Shervais, JW, Nielson, DE, 2012, Preliminary Results: Chemistry and Thermometry of Geothermal Water from MH-2B Test Well. Geothermal Resources Council Transactions, vol. 36, 689-692.

Nielson, DL, Delahunty, C., and Shervais, JW, 2012, Geothermal Systems in the Snake River Plain, Idaho, Characterized by the Hotspot Project. Geothermal Resources Council Transactions, v36, 727-730.

Schmitt, DR, Liberty, LM, Kessler, JE, Kück, J., Kofman, R., Bishop, R., Shervais, JW, Evans, JP, Champion, DE. 2012, The ICDP Snake River Geothermal Drilling Project: Preliminary overview of borehole geophysics. Geothermal Resources Council Transactions, v36., 1017-1022.

Shervais, JW, Nielson, DL, Evans, JP, Lachmar, T, Christiansen, EH, Morgan, L., Shanks, WCP, Delahunty, C, Schmitt, DR, Liberty, LM, Blackwell, DD, Glen, JM, Kessler, JE, Potter, KE, Jean, MM, Sant, CJ, Freeman, TG. 2012, Hotspot: The Snake River Geothermal Drilling Project -- Initial Report. Geothermal Resources Council Transactions, v36., 767-772. 


\title{
Appendix A
}

\section{Core Handling Procedures}

\author{
John Shervais and Katherine Potter
}

The core collected from MH-2 well provides a wealth of scientific knowledge about the deep hydrogeology of the SRP subsurface. Some examples of the more impressive core recovered are presented in Figures A.1-1 to A.1-4. To ensure that the core was collected and preserved properly to satisfy a host of scientific objectives the Hotspot core sampling team followed strict protocols in the field. The core handling procedures are described in the following sections.

\section{A.1 INTRODUCTION}

A prerequisite for the success of Hotspot: the Snake River Scientific Drilling Project was the acquisition and documentation of continuous cores in stratigraphic sequence. We describe here the procedures followed for core handling and preparation, the splitting of the core into working and archive halves, and primary core descriptions.

\section{A.2 CORE PREPARATION}

Core drilling was conducted 24 hours a day using wire-line techniques. Handling and curation procedures began when the inner core barrel was removed from the hole. After consultation with the core driller and a brief training program for the drilling crew regarding the importance of maintaining core orientation, sequencing and continuity, removal of the core from the inner core barrel was done by the drilling hands under the supervision of the core driller.

\section{A.2-1 Removal of the Core from the Core Barrel}

The core was removed from the core barrel by the drilling crew and placed in sequentially numbered PVC trays. The PVC trays were securely mounted on 8 " wide planks which provided stability and allowed drainage of water and drilling mud through $\sim 5 \mathrm{~mm}$ diameter holes spaced evenly along the bottoms of the PVC trays. Red paint was used to mark the tops of the trays, and drillers were careful to place the top of the core at the top of the tray. Once the trays were filled with core they were fitted with end blocks and the core trays were stacked in sequence adjacent to the drilling rig until they were moved to the processing tent by the core logging team.

For each core run, the drilling crew prepared a wooden block with the core run number, the top and bottom driller's depths, and the amount of core recovered. The wooden block was placed at the top of the appropriate PVC core tray and remained with the core run until the core was completely washed, marked, and boxed; the wooden blocks were place inside the core boxes with the core to mark the end of each run. 


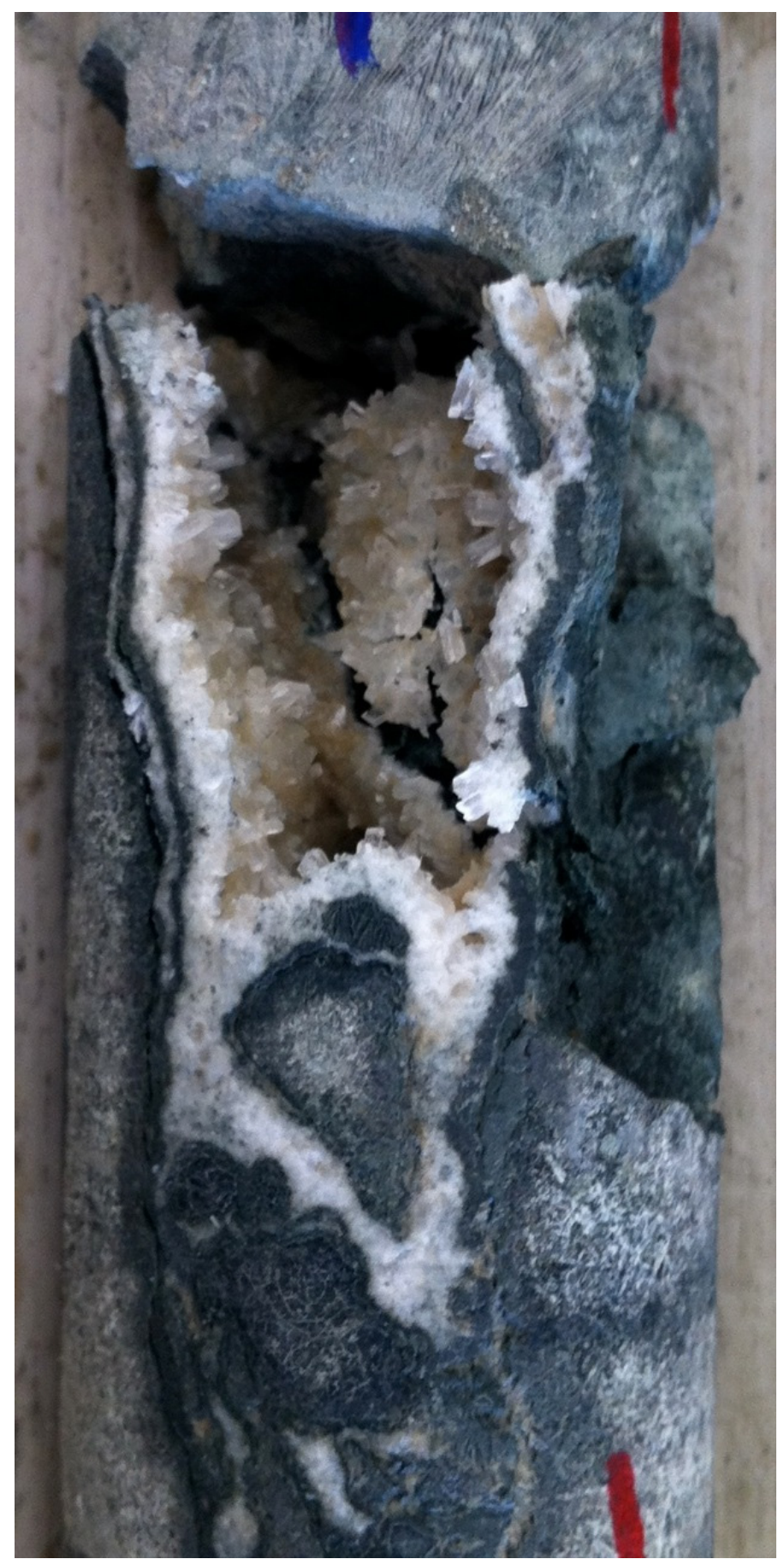

Figure A.1-1. Open fractures in NA-size core (2" diameter) lined with chlorite and prehnite. Depth 5756 feet, just below the artesian flow zone. 


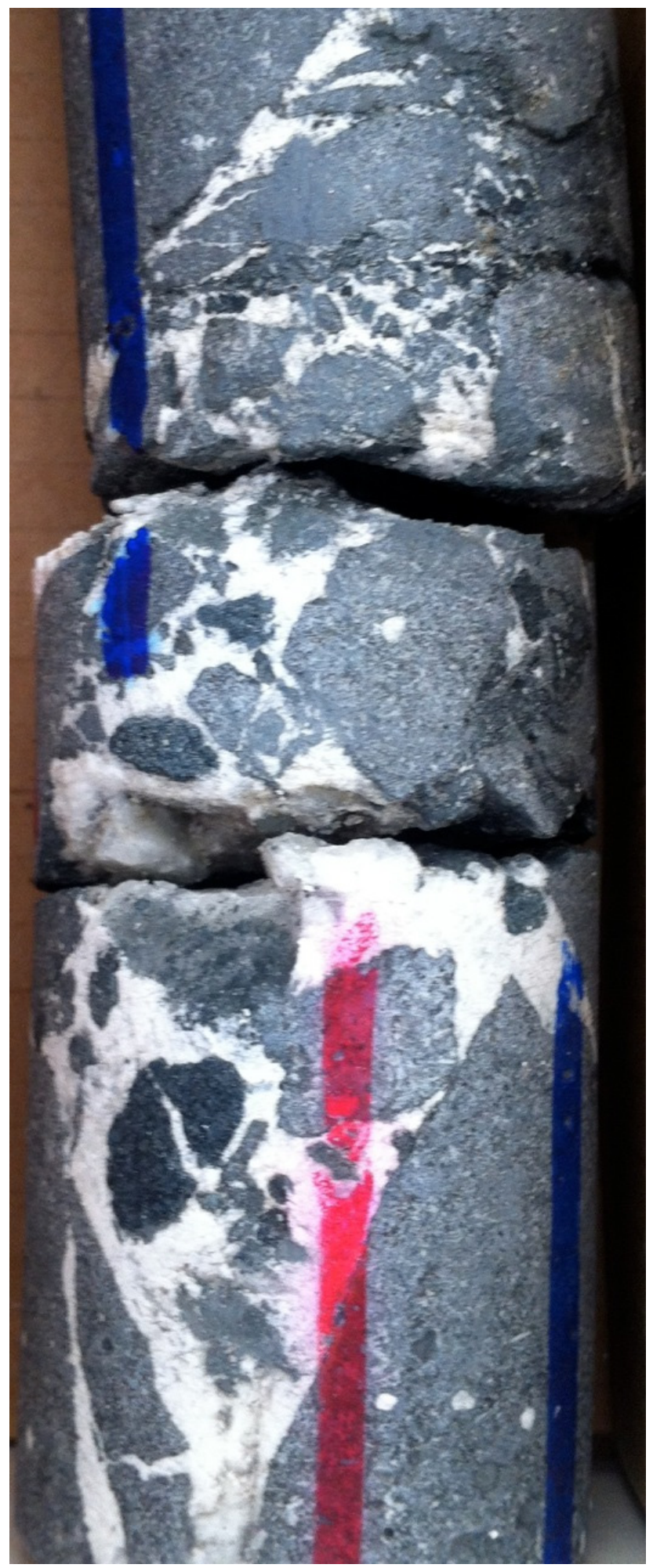

Figure A.1-2. Geothermal breccia cemented with quartz and calcite. The breccia implies steam explosions during older, higher temperature phase. Core $=2$ " across. 


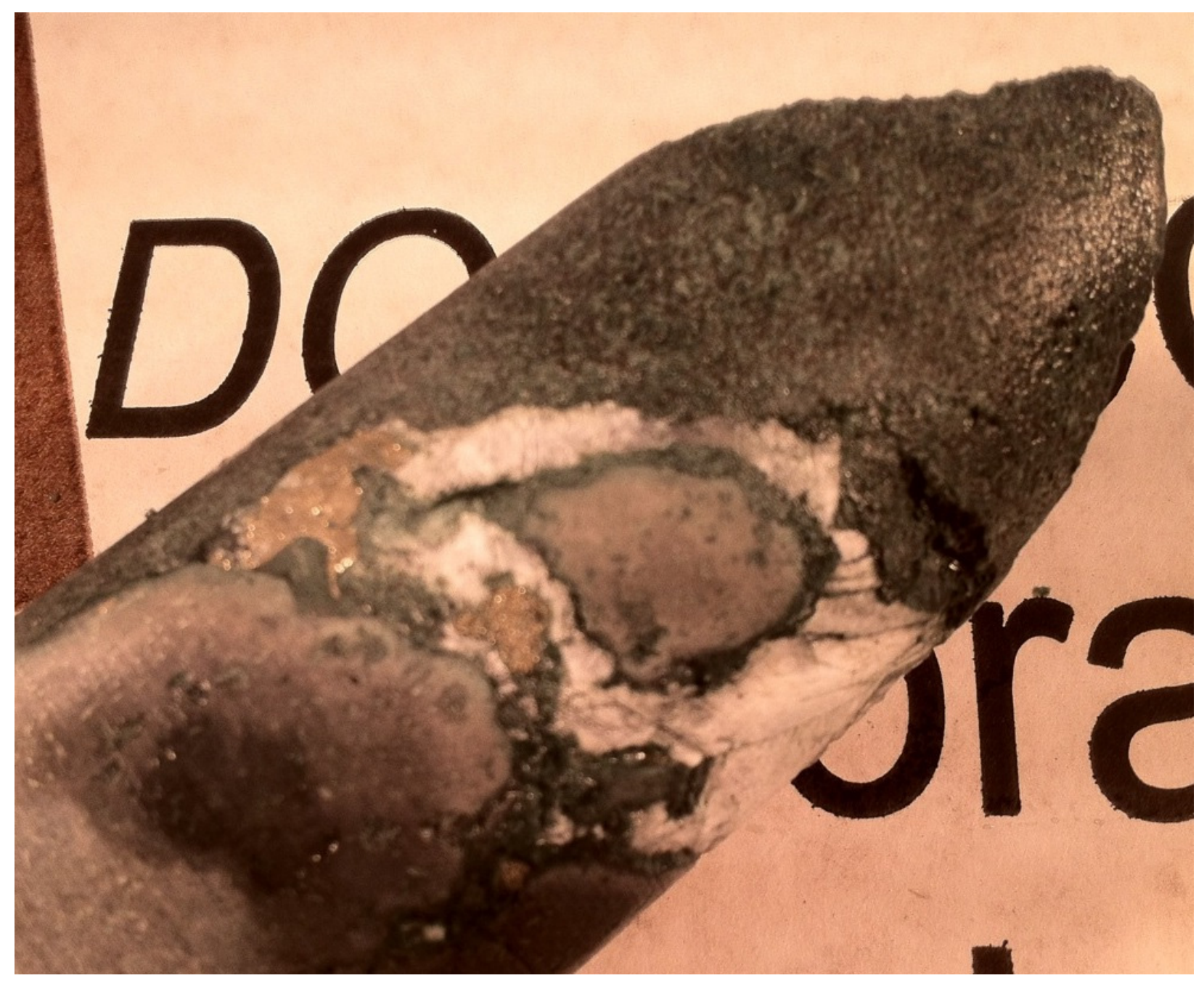

Figure A.1-3. Ore minerals pyrite and chalcopyrite in gangue matrix of quartz and calcite. Core $=2 "$ diameter. 


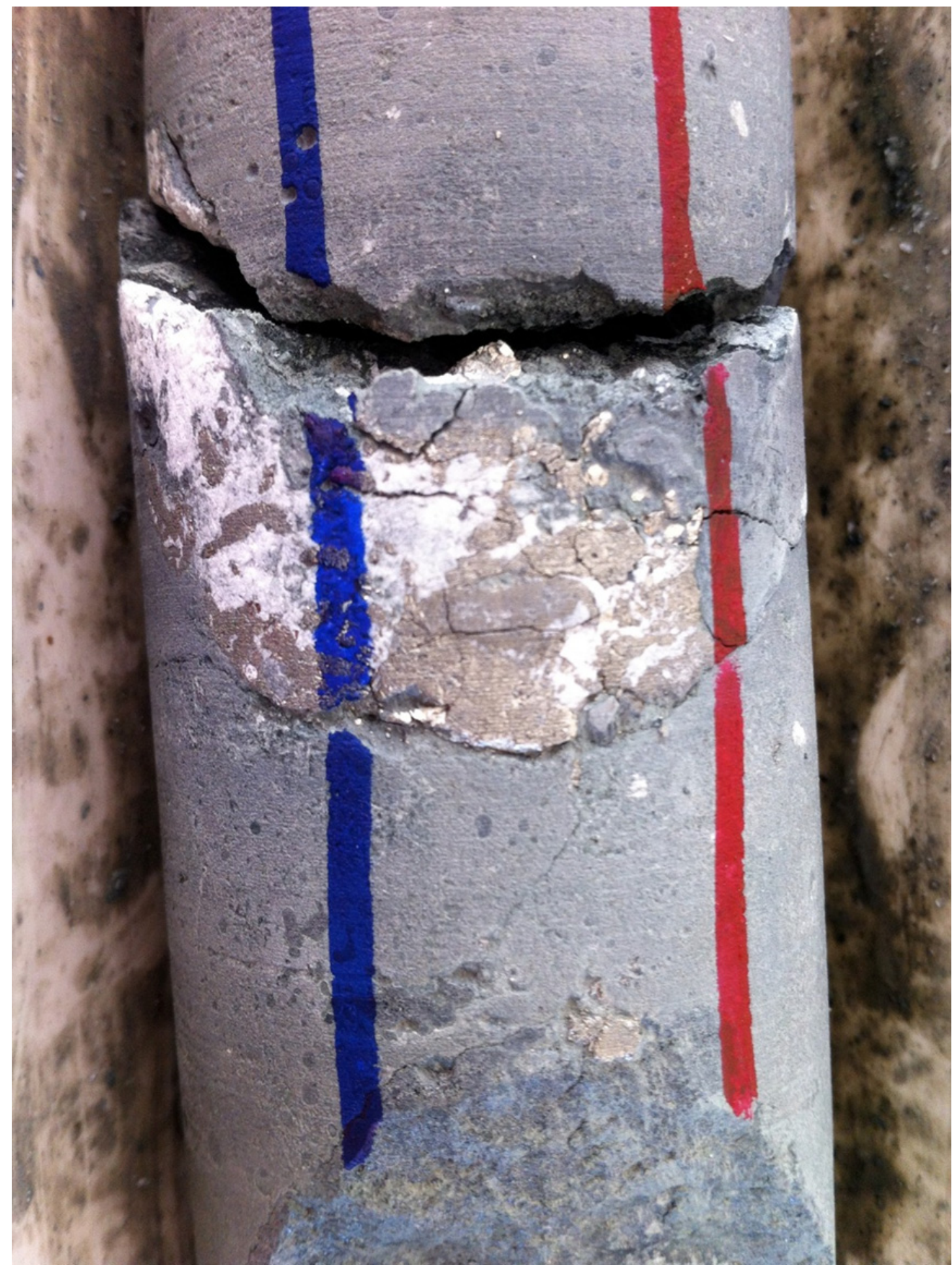

Figure A.1-4. Second image of ore minerals pyrite and chalcopyrite in gangue matrix of quartz and calcite. Core $=2$ " diameter. 
After each core was moved into the core processing tent, it was washed carefully and thoroughly using water hoses and brushes to remove drilling mud and rock cuttings. Special care was taken during the washing of soil or non-coherent core to prevent disruption or loss of core. The core was then dried with heat lamps or heat guns; once dry, each individual segment of core was marked with Red and Blue lines to indicate orientation (Red on Right where core is held vertically with top of core up).

\section{A.2-2 Run Information and Core Boxing}

Individual core runs were placed on working tables for preliminary logging. A Run Information Form (RIF) was filled out for each core run. The run number, driller's depths, date, and any unusual conditions related to the recovery of the core were noted on the RIF. The core was aligned, and individual pieces were fitted together where possible. The top of the core run being processed was compared to the bottom of the previous core run, and it was noted on the RIF whether these two pieces of core could be fitted together. The length of recovered core was measured in feet (to the nearest tenth) and this was recorded on the RIF. This length included the best estimates for lengths of rubble zones.

The core was then marked for "up" orientation with blue and red, permanent, waterproof felt-tipped pens (see Figure A.2-1.) If necessary, the surface of the core was first dried with a heat gun to prevent smudging of the pen marks. Orientation lines were marked twice on the core, on opposite sides, so that when the core was split into working and archive portions, each piece retained a set of lines. Delicate core (e.g., ash or soil) was sealed in shrink-wrap to preserve its integrity.

Preliminary identification of units was made and the location of contacts and unusual features (e.g., delicate glass-bearing sections, secondary mineralization, ash layers or baked contacts) were noted on the RIF. The core was put into core boxes that were segmented into five 2 -ft long rows. The boxes were marked with top (blue) and bottom (red) labels and oriented with the top of the box at the upper left corner. Core was placed in the box beginning with the top in the upper left corner, and continuing down and to the right. The drillers depth was marked on the box at both the top and bottom.

If necessary, the core was cut with a saw so that each 2-ft segment fit in the core box exactly. The wooden core run block was placed at the end of each run, labeled with the core run number and the ending driller's depth for that run and the core run number.

After each core box was filled, it was labeled with a black waterproof felt-tipped pen. The project name (HSDP), the box number, the core run number (or run numbers if the box contains material from more than one core run) and the driller's depth range of the core segment in the box were all noted on the box and its lid. Each box was then transferred to a copy stand for a medium resolution digital photograph (5 MP) of the full box plus centimeter scale, grey scale, and color bars, before the box was closed and stacked on a pallet for storage until transport to the USU Core Processing Lab. 


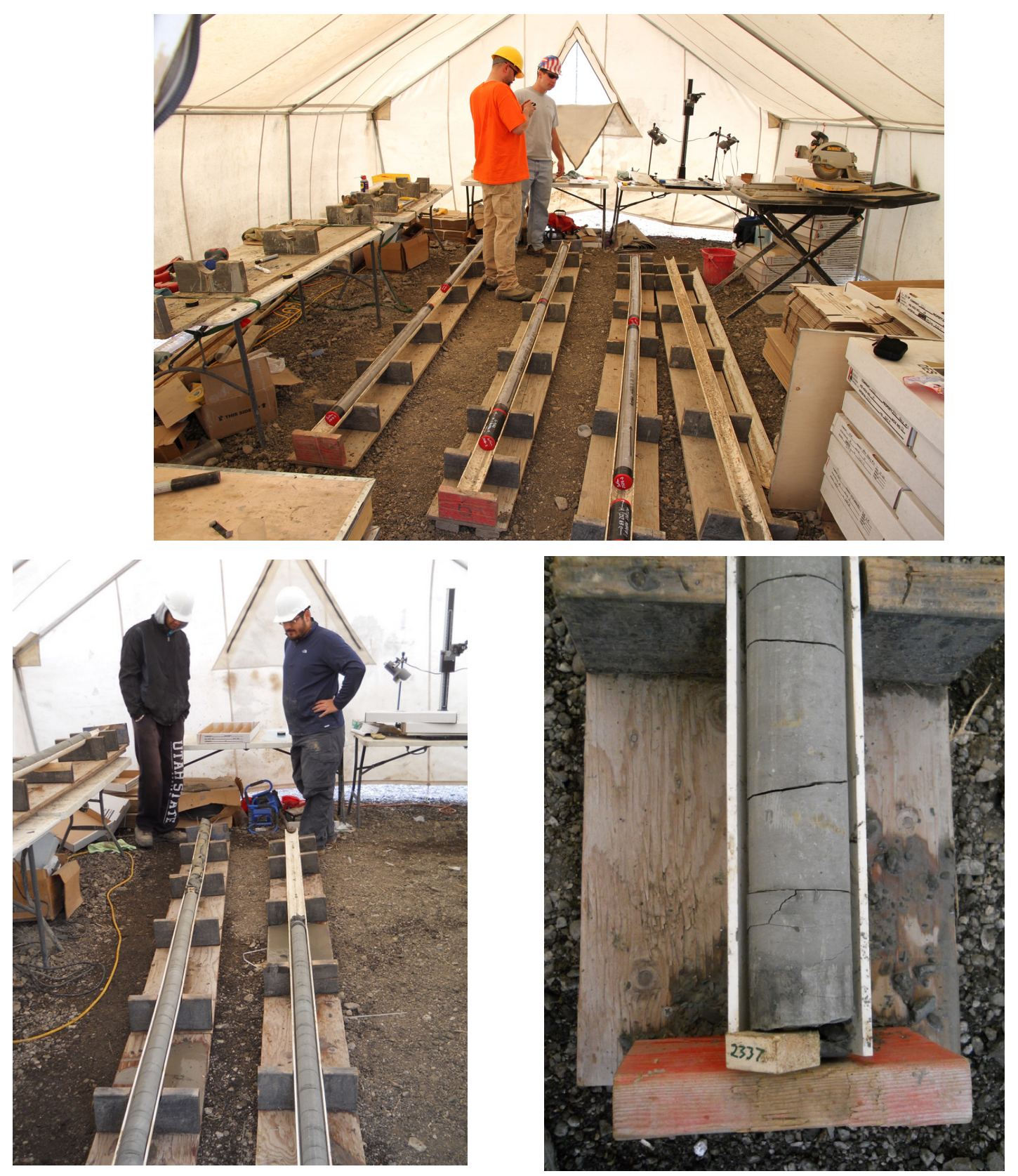

Figure A.2-1. On site core processing. Top: View of the core processing tent showing core trays, processing table, photo stand, and slab saw. Above Left: PVC core trays inside the core processing tent. Above right: Close up of lower end of PVC core tray (RED) with core and driller's wooden end block showing depth; amount cored and recovered shown on side of block. 


\section{A.3 CORE LOGGING PROCEDURES}

\section{A.3-1 General Statement}

Logging, i.e., the hand-specimen scale description of the core, is critical to the success of the Snake River Scientific Drilling Project since it provides the framework for all subsequent sampling and scientific study of the core.

The first step in core logging was to produce a box label for each box with all pertinent information about box number, depths, etc.. Each box was then photographed with a high-resolution digital camera (15 MP Leica V3) using a copy stand with metric scales, grey scale, and Kodak standard color bars, as well as the core box information sheet. Additionally, a high-resolution digital scan of each whole round core piece was made using the ICDP DMT ${ }^{\circledR}$ Core Scanner. Individual scans generally corresponded to the 2 - $\mathrm{ft}$ rows of the core box, however sections containing rubble were not scanned. Scanned images were entered into the DIS database along with information on depth interval of the scan, run number, and box number in which the core piece was stored. A $360^{\circ}$ image of the core was made by rotating the core on a set of rollers while the scanner moved down the length of the core. The result is a flat image of the outside surface of the core.

Standardized logging forms for lava flows, tephra, and sedimentary units were based on protocols from the Hawaii Scientific Drilling Project, updated for use with SRP rhyolites and sediments, and the modifications were made to the DIS database so that descriptive protocols could be accessed through drop-down menus.

\section{A.3-2 Detailed Logging Procedures}

Loggers were provided with a hand lens, ruler (metric and inches in tenths), references on rock and mineral classification, dilute hydrochloric acid. The log for each box of core consists of a written description of the core prepared using the standardized logging forms, which were filled out in hard copy before being upload into the ICDP DIS database.

\section{A.3-2-1 Identifying Contacts and Lithologies}

Contacts between units basalt-sediment, basalt-rhyolite, rhyolite-sediment, as well as flow contacts within basalts (basalt-basalt), rhyolites (rhyolite-rhyolite), and sediments (e.g., sand-gravel). All contacts were noted on the logging forms with drillers depth and distance from the nearest upper section boundary (as defined by the DIS database). For flow contacts between basalt flows or rhyolite units, the nature and basis for the contact identification are described. Top and bottom depths of the box and the top depth for each unit in the box were recorded relative to the top depth of each run. All absolute depths are automatically calculated in the database from the relative depth information entered by the logger.

When internal boundaries were present within units (e.g., lobes of a pahoehoe flow; rubble in an aa flow; changes in sorting or grain size in hyaloclastites; glassy pillow margins; or the presence of interpillow breccia), their depths were recorded and their locations were marked with thin dashed lines on the digital image of the core box.

For lavas, the groundmass texture was determined (glassy, cryptocrystalline, microcrystalline, fine-grained $(<1 \mathrm{~mm})$, medium-grained $(1-2 \mathrm{~mm})$, coarse-grained $(>2 \mathrm{~mm}))$. Comments on the groundmass (e.g., mineralogy and texture) were added when relevant. Vesicle abundance was visually estimated in volume $\%$ (sparse $(<5 \%)$, moderate $(5-15 \%)$, abundant $(15-30 \%)$, very abundant $(>30 \%)$, and variable). Average vesicle size (small $<1 \mathrm{~mm}$, medium $1-5 \mathrm{~mm}$, and large $>5 \mathrm{~mm}$ ), shape (round, sub-rounded, sub-angular, angular), and aspect ratio (equant, horizontally elongated, vertically elongated, inclined - if inclined, the dip relative to the axis of the core was included) were recorded. Comments were also made on the vesicle distribution within the unit. 
The extent of alteration was estimated in volume $\%$ of the core as a whole (excluding alteration along fractures): fresh ( $<2 \%$ alteration), slightly altered ( $2-10 \%$ alteration), moderately altered $(10-40 \%$ alteration), highly altered ( $>40 \%$ alteration). Secondary minerals were described and identified where possible (e.g., clays, zeolites, etc.). The extent of fracturing was estimated based on the number of fractures/foot (none, weakly fractured, $(<4$ fractures/ft), moderately fractured (4-10 fractures/ft), highly fractured ( $>10$ fractures/ft), or rubble. Loggers noted drilling induced fractures based on their lack of alteration and orientation.

When appropriate, sedimentary features were described (e.g., grain size, sorting, color, and dip of bedding). Lacustrine sediments from the Mountain Home site were recovered in plastic liners and handled differently than the other core, as described below.

\section{A.3-2-2 Lake Sediment Core}

Sediment core from the Mtn Home site was handled differently from the other core. Because it is thought to consist entirely of Pliocene-Pleistocene lake sediments below $200 \mathrm{~m}$ depth, this core will be drilled with plastic core liners and sent directly to the LaCore facility at the University of Minnesota for processing. As a part of the initial core description we plan (1) multi-sensor continuous whole-core logging; (2) core opening and splitting longwise for initial core description and high-resolution imaging; (3) smear slide observations of lithology; (4) preliminary diatom biostratigraphy on 200 samples, i.e., ca. 1 sample per $3 \mathrm{~m}$ involving scanning electron microscope imaging of diatoms. This latter part is listed as a part of initial core description, because it is essential to gain understanding of the preliminary age model and hence sedimentation rates and to gain better understanding of the depositional setting at the drill site. Intact clearly labeled lake sediment cores in capped and taped standard GLAD butyrate liner were shipped to the LacCore facility at the University of Minnesota. 
INTENTIONALLY BLANK

A-10 


\title{
Appendix B
}

\section{Fracture Analysis}

\author{
SUMMARY OF FUNDAMENTAL FRACTURE DATA IN THE MH-2 BOREHOLE, \\ MOUNTAIN HOME AIR FORCE BASE, MOUNTAIN HOME, IDAHO
}

James Kessler, Douglas Schmitt, James Evans

\section{B.1 INTRODUCTION}

Fluid recovery in both naturally fractured geothermal systems and enhanced geothermal systems (EGS) is often accomplished via fluid flow through connected fracture networks that convectively transports heat to the production well. Successful exploitation of geothermal resources relies upon effective characterization of fracture networks in fractured reservoirs. Fracture density, frequency, aperture, and orientation are measurable characteristics that affect fracture connectivity and permeability of a fracture network. Those characteristics are measured in both core samples and with wireline borehole geophysical instruments. Coring work for Project Hotspot recovered $>90 \%$ of whole rock core from the Mountain Home-2 borehole (MH-2) to a total depth (TD) of 1,821 m (5,976 ft). A full suite of borehole geophysical data was also collected from the borehole.

\section{B.2 OBJECTIVE}

The objective of this project is to assess the potential for geothermal energy development through analysis of fracture permeability. Here we present the distribution and orientations of fractures in MH-2. We have collected the fracture data and summarized fundamental aspects of the data here. Controls on fracture permeability include fracture density, cumulative fracture frequency, fracture orientation (azimuth/strike and dip), and fracture aperture. These data constitute fracture stratigraphy and will be correlated to lithology and mechanical stratigraphy to determine if fracture development is dependent upon any aspect of lithological and/or mechanical properties.

\section{B.3 METHODS}

We measured fracture characteristics from core samples and mapped fractures in acoustic televiewer logs collected in the MH-2 borehole over the zone of interest (ZOI). The ZOI includes the interval of the televiewer $\log$ from $1,287 \mathrm{~m}(4,223 \mathrm{ft})$ to $1,597 \mathrm{~m}(5,238 \mathrm{ft})$. Each fracture measured from core was identified as naturally occurring or drilling-induced. Naturally occurring fractures are identified by recognizing indicators that the fracture is open or was open at some time in the past. Typical indicators are oxidation on or around the fracture plane, presence of secondary mineralization that has sealed or partially sealed an open fracture, alteration of host rock, and/or slip indicators on the face of a fault. The presence of any one or more of these characteristics requires that the fracture was open at some time before the borehole was drilled.

Particular morphologies can be identified that are indicative of drilling induced fractures. Centerline fractures, petal fractures, petal-centerline fractures, core edge fractures, saddle fractures, and disking are indicative of fractures formed post-drilling as a result of the release of stress on the core or the redistribution of stresses around the borehole wall (see Figure B.3-1; Schmitt et al., 2012). Drilling induced fractures occur in slightly different places in the core compared to the borehole wall due to the differences between the release of stress on the core sample and the redistribution of stresses around the borehole wall that concentrates compressive stresses in relation to the minimum and maximum principal stress directions. 


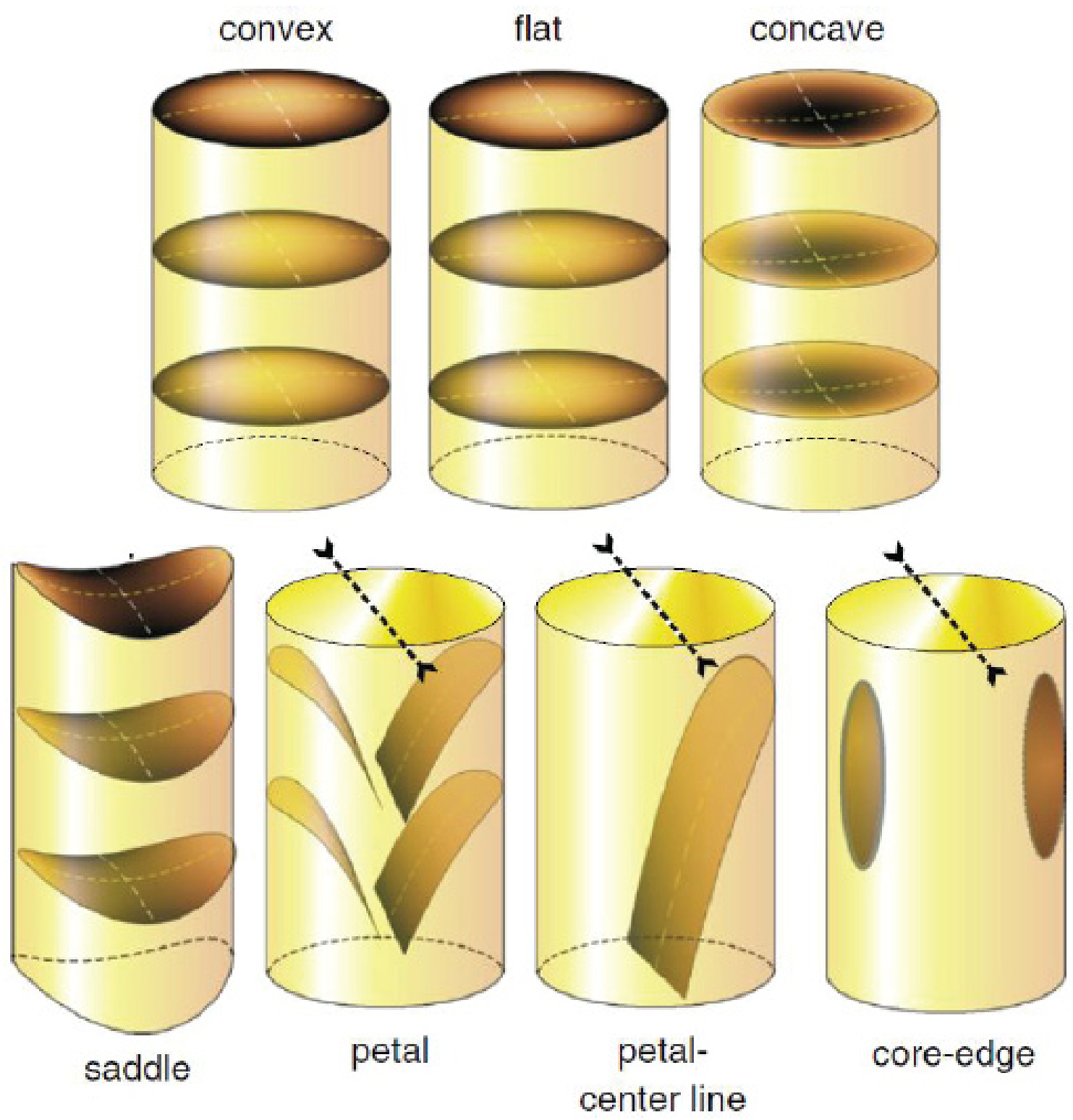

Figure B.3-1. Drilling-induced fracture classifications as a result of tensile fractures in core (modified from Schmitt et al., 2012).

Other induced fractures are identified separately from drilling induced and include those that are a result of the act of the drill bit on the core or handling after that the core is removed from the core barrel. These are identified through a lack of planar fracture or induced morphologies, beveled edges on subhorizontal fractures indicates the two pieces of core spun against each other while in the core barrel. All induced fractures have clean, fresh faces that lack any indication of exposure before drilling and handling. 
Dip and aperture are measured in reference to the strike line of a fracture plane. The core is oriented so that the strike line is pointed vertically and the dip is measured with a digital protractor relative to horizontal. The borehole deviates little from vertical so is assumed to be vertical and the long edge of the core can be used as a reference to vertical. Aperture is measured with the core oriented the same way so that aperture could be measured perpendicular to the fracture faces and not at some apparent thickness at another location on the outside of the core. Aperture can only be measured in fractures that are closed or sealed. Some broken fractures can be fit together and the mineral fill is preserved enough to confidently measure aperture. Minerals observed to fill fractures include quartz, calcite, clays (chlorite and smectite), zeolite (laumontite), pyrite, and chalcopyrite.

\section{B.4 RESULTS}

The spatial distribution of fracture density, cumulative fracture frequency, dip direction or strike, and dip angle will be used to define fracture stratigraphy and discrete fracture populations that can be correlated to lithology and mechanical stratigraphy. Fracture density (see Figure B.4-1) distribution shows that fractures cluster with respect to depth in definable ways. We will use the distribution of the fracture population to define discrete zones along the depth profile of fracture densities. Those zones constitute fracture stratigraphy and are the framework under which we consider the distribution of other fracture characteristics and rock properties.

The fracture density histogram and cumulative fracture frequency curve (see Figure B.4-2) show us the pattern of fracture distribution with depth in MH-2. Most notable are two significant sections of the borehole that lack fractures from $\sim 1,349 \mathrm{~m}(4,425 \mathrm{ft})$ to $\sim 1,384 \mathrm{~m}(4,540 \mathrm{ft})$ and $\sim 1,481 \mathrm{~m}(4,860 \mathrm{ft})$ to $\sim 1,532 \mathrm{~m}(5,025 \mathrm{ft})$. Thinner sections can be defined based on the presence of intense fracture populations or a lack of fractures in Figure B.0-3. The data can be subdivided into as few as 5 fracture units or as many as 20 or more, depending on what is most appropriate for the study. In this case, we will define the appropriate number to statistically correlate fracture stratigraphy with lithological units and mechanical stratigraphic units that are defined by the distribution of rock properties in the borehole. 


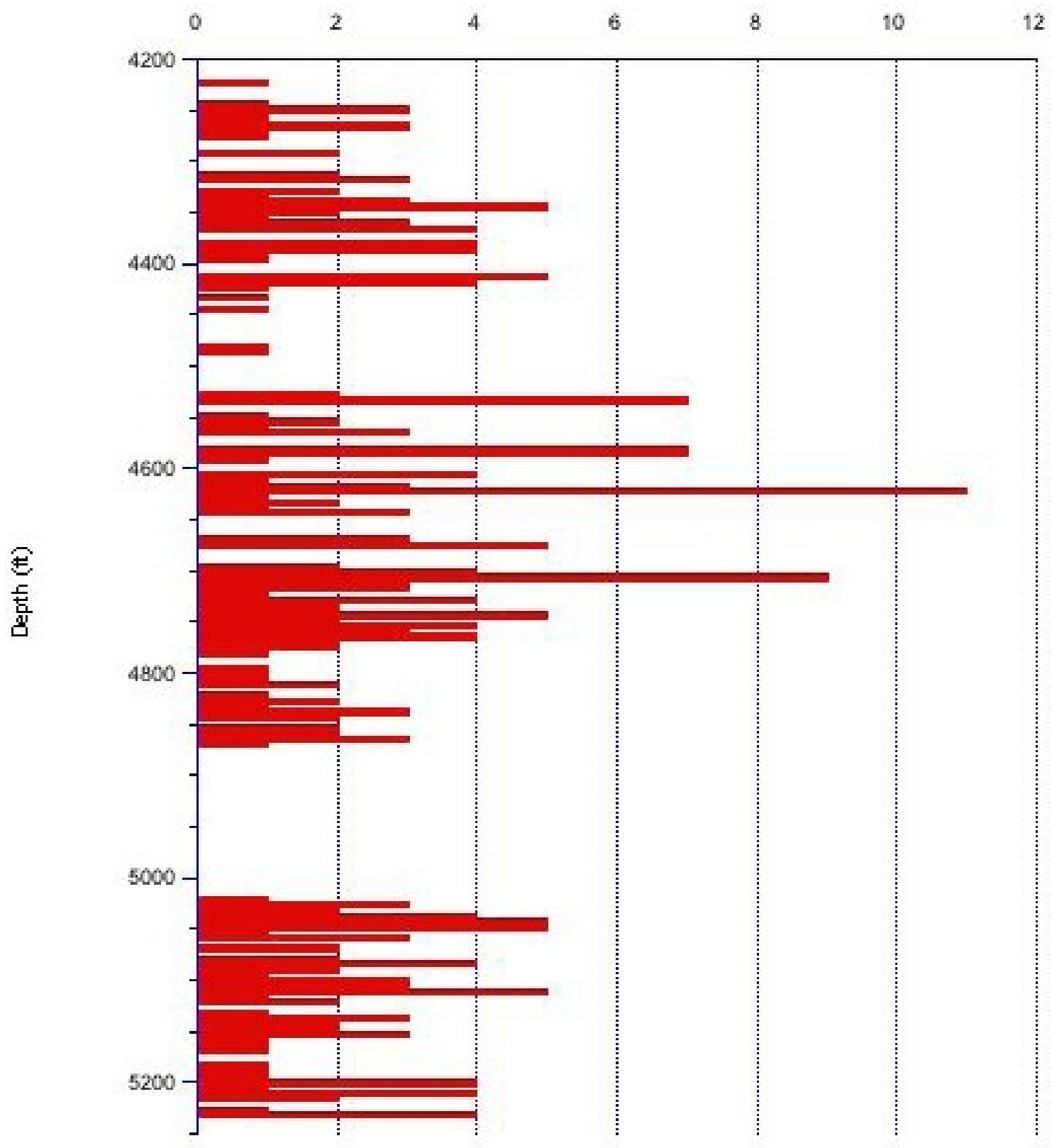

Count

Figure B.4-1. Fracture frequency distribution plotted as fracture density (\# fractures $/ 5 \mathrm{ft}$ of borehole depth). 


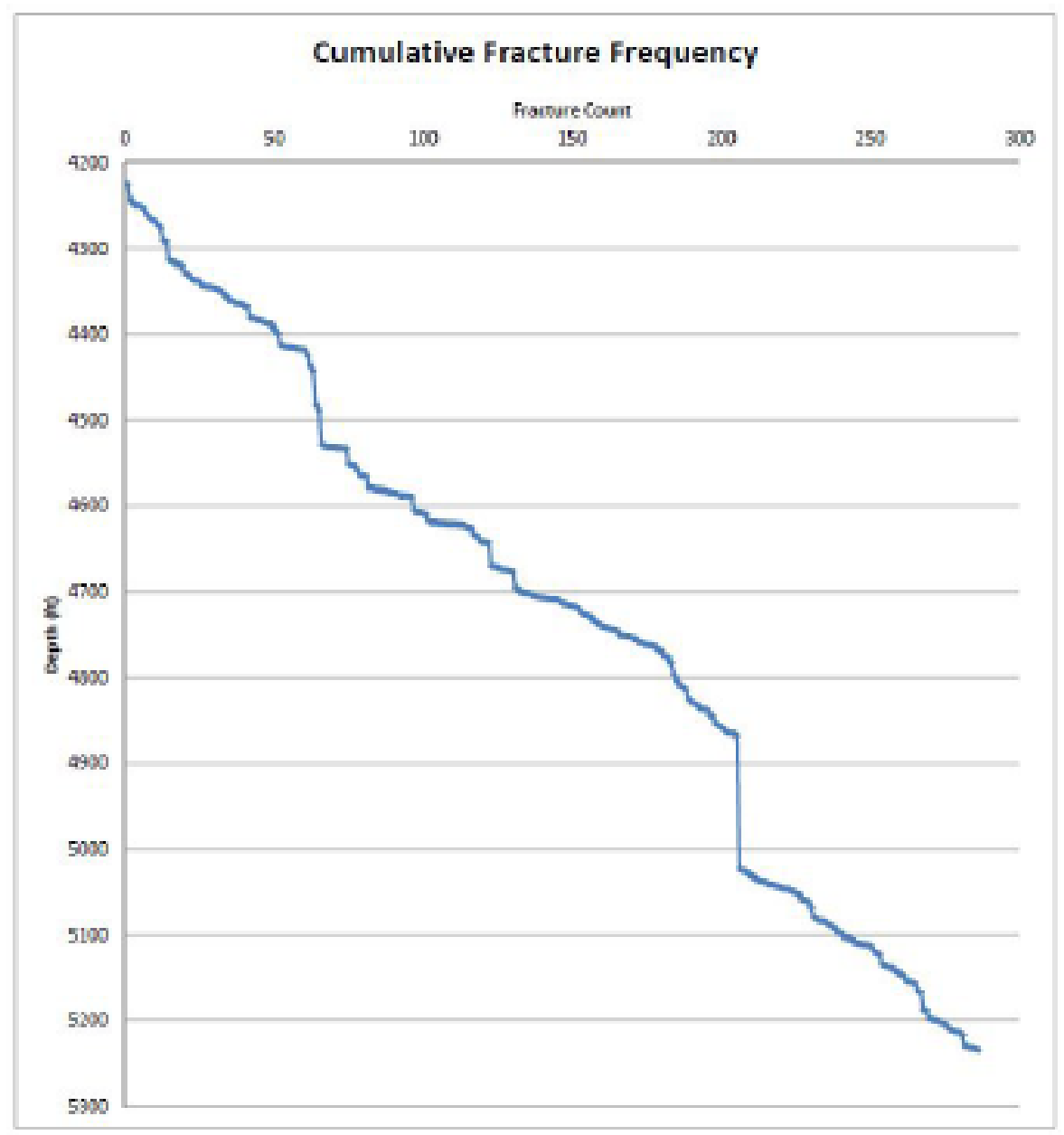

Figure B.4-2. Fracture frequency distribution plotted as cumulative fracture frequency.

Fracture aperture and orientation are intrinsically linked to fracture permeability. The distribution of apertures (see Figure B.4-3) shows that the majority of the fractures have small apertures that are $<10-15 \mathrm{~mm}$. Large $(>20 \mathrm{~mm})$ fractures and/or voids are present in the population of fractures. The large, standout voids are identified by visible gaps in televiewer data and by a considerable lack of core recovery in the drilling record. Core samples from large-aperture zones show significant high-temperature secondary mineralization. Large voids could be potential conduits for significant flux of hydrothermal fluid based on potential volume, if the voids are extensive enough. The presence of secondary mineralization is an indicator of previous hydrothermal fluid flow. The largest of voids, those $>40 \mathrm{~mm}$, are listed in Table B.4-1. The large aperture fracture zone inferred at 1,745 $\mathrm{m}(5,725 \mathrm{ft})$ depth is inferred from the poor core recovery $(<50 \%)$ and the occurrence of voluminous artesian flow from this zone. The aperture of $>48 \mathrm{~mm}$ is inferred from the NQ core diameter $(48 \mathrm{~mm})$, assuming that aperture size exceeds core diameter in zones with $<50 \%$ recovery. 


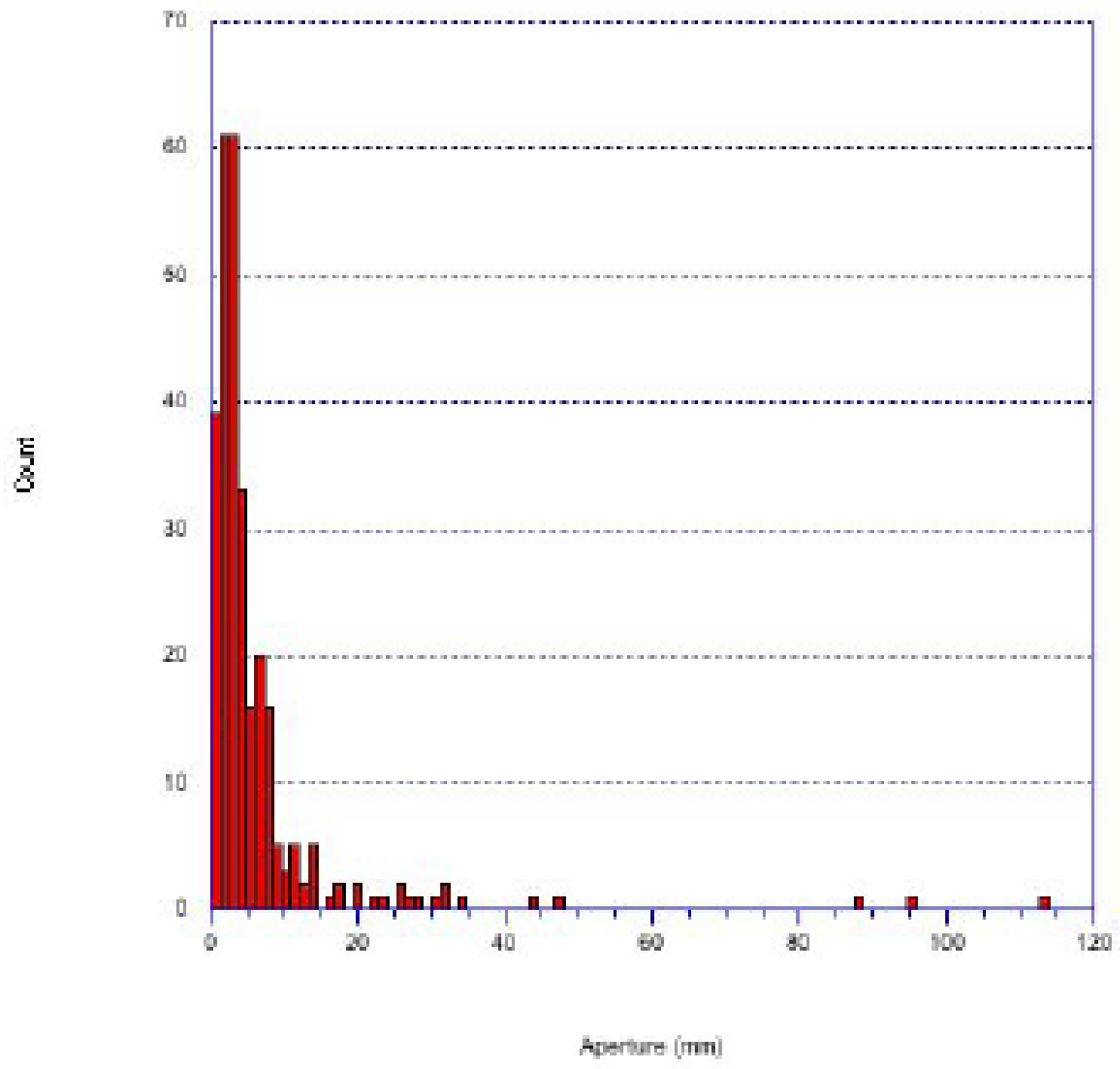

Figure B.4-3. Aperture histogram depicting the distribution of apenure sizes in the ZOI.

Table B.4-1. Depths and apertures of large voids in the ZOI.

\begin{tabular}{|c|c|c|}
\hline $\begin{array}{c}\text { Depth } \\
(\mathrm{m})\end{array}$ & $\begin{array}{c}\text { Depth } \\
(\mathrm{ft})\end{array}$ & $\begin{array}{c}\text { Aperture } \\
(\mathrm{mm})\end{array}$ \\
\hline 1,328 & 4,356 & 47.6 \\
\hline 1,347 & 4,418 & 113.0 \\
\hline 1,396 & 4,581 & 95.4 \\
\hline 1,407 & 4,618 & 88.7 \\
\hline 1,534 & 5,032 & 43.4 \\
\hline 1,745 & 5,726 & $>48$ \\
\hline
\end{tabular}


Fracture orientation is defined by strike and dip and plotted as a pole normal to the plane of the fracture (see Figure B.4-4) and by the azimuth of dip direction and dip angle of each fracture. The population of fracture data cluster in primary, secondary, and tertiary azimuth directions (see Figure B.4-5). The primary cluster dips generally in the NNW direction while the secondary cluster dips to the SSE, and the tertiary cluster dips to the WSW direction. Dip angles are very consistent (see Figure B.4-6) and show that the majority of the fracture population over the ZOI dips between 40 and 80 degrees. Dip angles are consistent with the high normal range-front faults that bound the graben. However, while the dip angles are consistent, the orientations of the fractures vary from the regional geological structure.
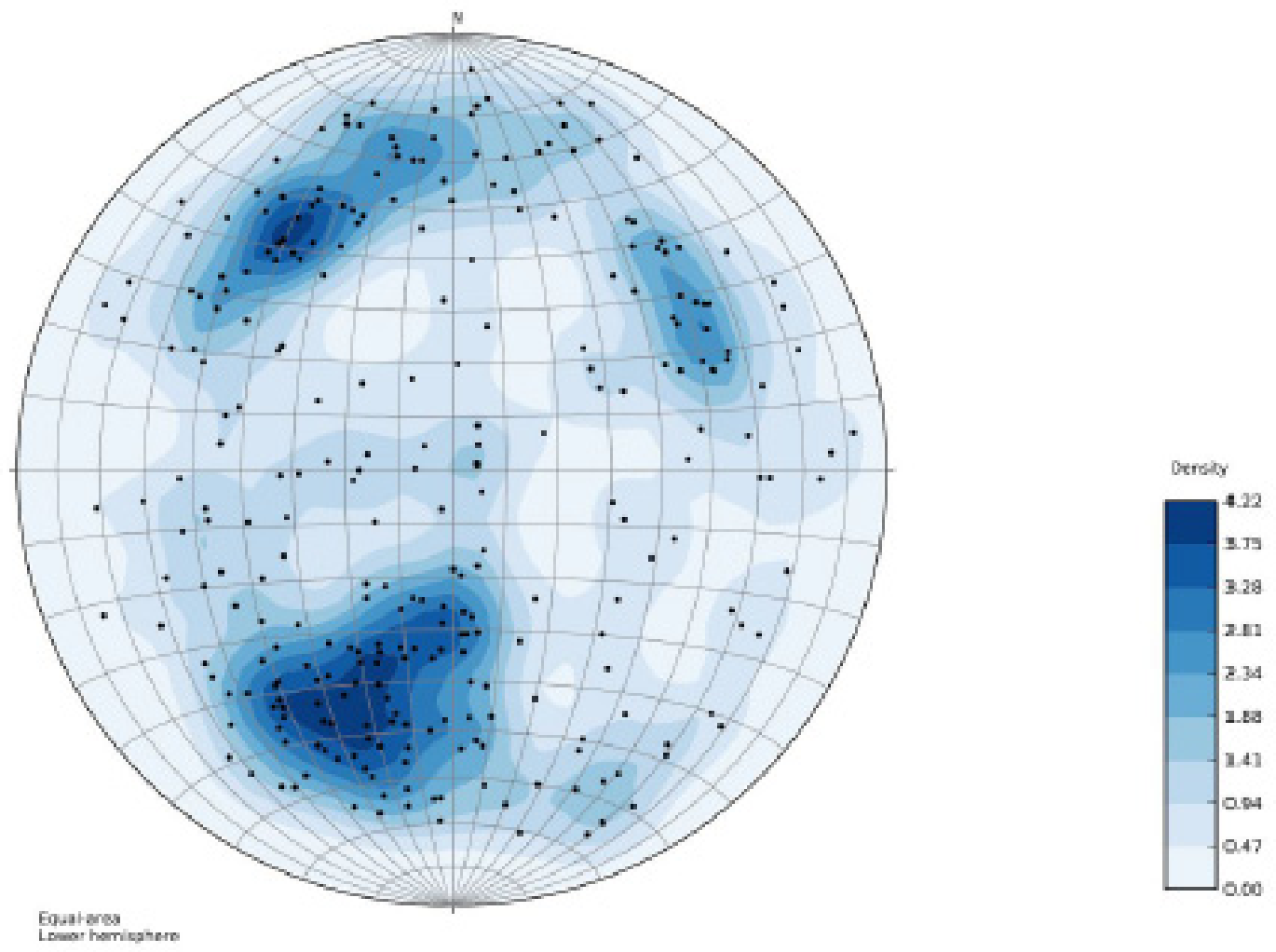

Figure B.4-4. Equal-area, lower-hemisphere stereonet plot of the poles-to-plane for fractures over the ZOI. 


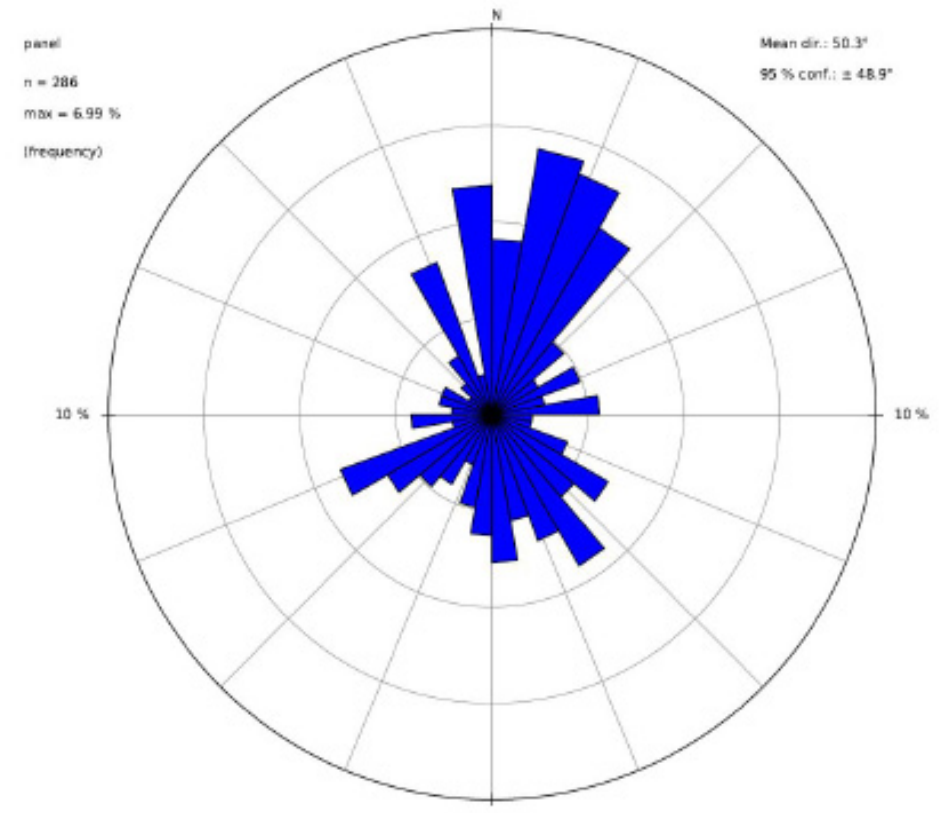

Figure B.4-5. Rose diagram depicting the distribution of fracture dip azimuths.

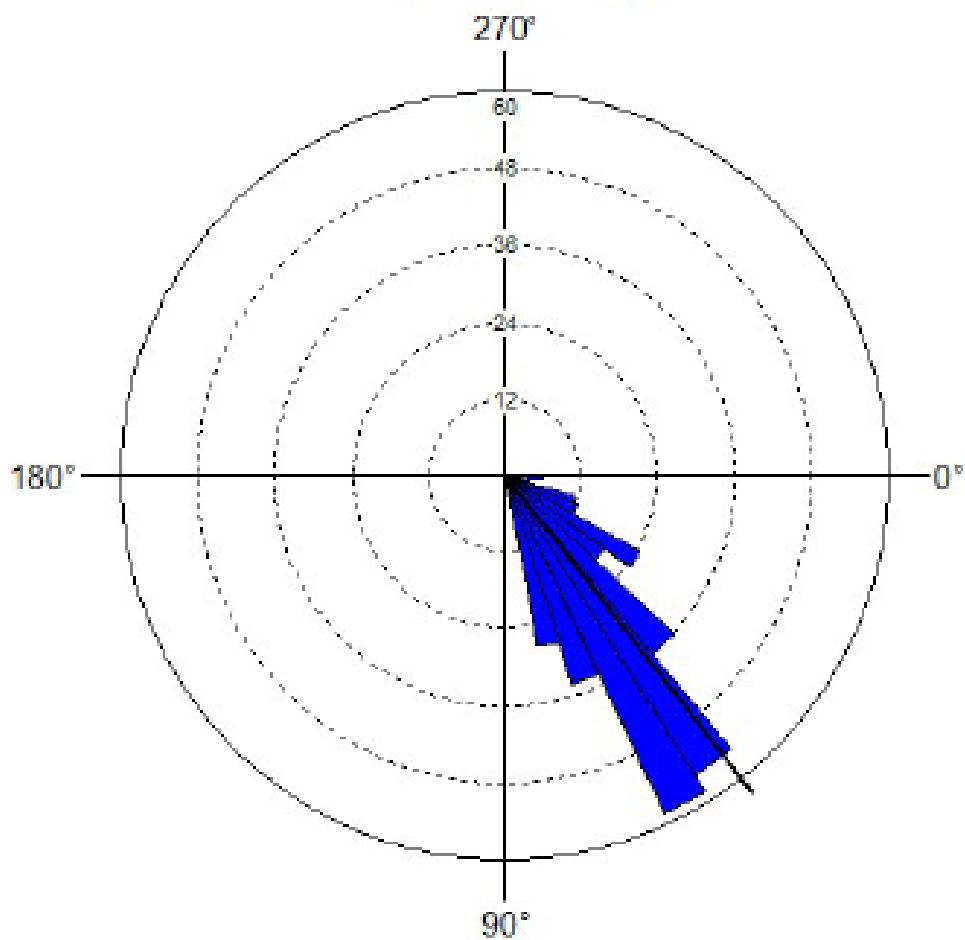

Figure B.4-6. Rose diagram depicting the distribution of dip angles from alIfractures in the ZOI. 
The range-front faults offset Miocene volcanic rocks and dip at high angles to the southwest and strike N55-60W. Quaternary faults are clustered in two sets oriented N85W and N60W (Shervais et al., 2002). The primary cluster of fractures in the ZOI is oriented roughly N80W and dips at high angles to the NE (see Figure B.4-4). The secondary cluster of fractures strikes N45E and dips to the SE while the tertiary cluster strikes $\mathrm{N} 30 \mathrm{~W}$ and dips to the SW. The orientation of the primary cluster of fractures is oriented consistently with one set of Quaternary faults (N80-85W), but dips in an antithetical direction. Slip indicators on many of the fracture surfaces may be oriented using televiewer data and might give insight into the reason for the inconsistency between the fracture population in the MH-2 borehole and the regional geological structures.

\section{B.5 FUTURE WORK}

The next phase of this project will be to conduct a stress analysis to determine the orientation and magnitudes of the three principal stresses ( $\mathrm{Sv}, \mathrm{Sh}, \mathrm{SH}$ ). Principal stress orientations are identified from borehole breakouts and induced tensile fractures on the televiewer log. Dipole sonic data (Vs and Vp) and bulk density data, measured from core samples, are used to calculated Young's modulus (E) and Poisson's ratio (v). Rock strength will be calculated from uniaxial compression strength (UCS) experimental data. Those data will be used to calculate the magnitudes of the principal horizontal stresses using the method from Zoback (2003). Vertical principal stress will be calculated using the relationship $\mathrm{Sv}=\rho \mathrm{gh}$. Where $\rho$ is average density of the overburden, $\mathrm{g}$ is acceleration due to gravity, and $\mathrm{h}$ is depth of the ZOI. Mercury-injection porosimetry tests will yield porosity, permeability, and bulk density data. Those data along with the fracture data and results of the stress analysis will be used as spatial parameters and boundary conditions in a discrete fracture network (DFN) model using the industry-standard code FracMan ${ }^{\mathrm{TM}}$.

\section{B.6 BIBLIOGRAPHY}

1. Schmitt, D.R., Currie, C.A., and Zhang, L., 2012, Crustal Stress Determination from Boreholes and Rock Cores: Fundament Principles, Tectonophysics, v. 580, pp. 1-26.

2. Shervais, J.W., Gaurav Shroff, S.K. Vetter, Scott Matthews, B.B. Hanan, and J.J. McGee, 2002, Origin and Evolution of the Western Snake River Plain: Implications From Stratigraphy, Faulting, and the Geochemistry of Basalts Near Mountain Home, Idaho, in Bill Bonnichsen, C.M. White, and Michael McCurry, eds., Tectonic and Magmatic Evolution of the Snake River Plain Volcanic Province: Idaho Geological Survey Bulletin 30, p. 343-361.

3. Zoback, M.D., Barton, C.A., Castillo, D.A., Finkbeiner, T., Grollimund, B.R., Moos, D.B., Ward, C.D., Wiprut, D.J., 2003, Determination of Stress Orientation and Magnitude in Deep Wells, International Journal of Rock Mechanics \& Mining Sciences, v. 40, pp. 1049 - 1076. 
INTENTIONALLY BLANK

B-10 


\title{
Appendix C
}

\section{Analysis of Clay Mineralogy at Mountain Home Well \#2}

\author{
John Shervais and others
}

\section{C.1 INTRODUCTION}

X-ray diffraction spectrometry is the primary method used by mineralogists to identify and quantify clay mineral analyses. Because clay minerals are typically very fine grained, and may form interlayered structures with other phyllosilicates, optical and micro-analytical methods are less useful than for other mineral species. Clay minerals form typically at low temperatures and pressures from pre-existing high temperature phases (e.g., feldspar), but the types and structures of the clay minerals are themselves controlled in part by formation temperatures. The transition in structural order-disorder from low to higher, and from simple clays to mixed layer clay or mixed layer phyllosilicates, is also a function of formation temperatures.

\section{C.2 DATA ACQUISITION AND METHODOLOGY}

X-ray diffraction analyses were performed at Vassar College using a Bruker $\Theta: \Theta$ diffractometer at $30 \mathrm{kV}$ and $10 \mathrm{~mA}$ with a $0.6^{\circ}$ incident beam slit size. Samples were routinely run with a 0.02 step size and a count time ranging from 0.4 to $1.0 \mathrm{sec} / \mathrm{step}$ from $2^{\circ}$ to $35^{\circ} 2 \Theta$.

Twenty-two samples from between $750 \mathrm{~m}$ and $1800 \mathrm{~m}$ depth were analyzed as randomly oriented $<250 \mu \mathrm{m}$ powders. From these, 9 have been chosen for detailed study which will include $<2 \mu \mathrm{m}$ oriented-grain mounts to be analyzed air-dried and after exposure to ethylene glycol vapor at $60^{\circ} \mathrm{C}$ for 24 . The oriented-grain diffraction patterns will be modeled using the computer software NEWMOD to ascertain stacking sequence, layer composition, and degree and nature of disorder.

Clay separate scans were analyzed using a one hour or two hour scan depending on the treatment. The scanning parameters for each treatment were a line scan at $0.25^{\circ} 2 \Theta / \mathrm{min}$ with $0.5^{\circ}$ slit size and a $10 \mathrm{~mm}$ window. Each clay separate sample was run after each stage of a three-stage treatment process. The first stage is exposure to room temperature atmosphere and it is run from $3^{\circ}$ to $33^{\circ} 2 \Theta$. The second stage of the treatment subjected the samples to ethylene glycol vapors at $60^{\circ} \mathrm{C}$ for 24 hours and then run in the XRD from $3^{\circ}$ to $18^{\circ} 2 \Theta$. Due the volatility of ethylene glycol, after about one hour the sample begins to change thickness which could cause inaccurate results. For this reason, glycolated samples were only run for one hour, from $3^{\circ}$ to $18^{\circ} 2 \Theta$. Stage three consisted of heating the samples to $500^{\circ} \mathrm{C}$ for two hours, then cooled and run from $3^{\circ}$ to $33^{\circ} 2 \Theta$.

\section{C.3 DATA ANALYSIS}

Preliminary results indicate that from $760 \mathrm{~m}$ to $1750 \mathrm{~m}$ depth ( 2500-5800 feet), the predominant tri-octahedral clay mineral is smectite, most likely the variety saponite, that increases in diffracting domain size with depth. From $1750 \mathrm{~m}$ to $1800 \mathrm{~m}$ depth ( $\sim 5800$ to 5900 feet) the predominant clay mineral is corrensite, a 50:50 R1 mixture of chlorite:smectite $(\mathrm{C} / \mathrm{S})$. Below $1800 \mathrm{~m}$, smectite is again present.

Ten samples have been selected for further study: 2 smectite-rich samples above the corrensite zone, one smectite-rich sample below it, and 7 in or near the corrensite zone. The $<2 u m$ fraction will be separated from these and analyzed in oriented powder mounts both air-dried, and solvated with ethylene glycol. We will model the patterns with NEWMOD to study the nature of interstratifications, as well as changes in diffracting domain size. We hope to study the conditions of the formation of corrensite from saponite, and also to understand why saponite occurs below the corrensite zone. 


\section{C.4 ANALYSIS OF MINERALOGY DATA}

The change from smectite to chlorite/smectite (corrensite) with depth correlates with increasing temperature, as observed in the temperature logs. In experiments, $\mathrm{C} / \mathrm{S}$ forms at around $250^{\circ} \mathrm{C}$, but it is unlikely that these rocks have been that warm. However, studies of corrensite in basalts are few - most studies focus on sedimentary rocks, and are rarely correlated with temperature.

X-ray diffraction studies of vein fillings done at Utah State University and the University of Utah have also documented the occurrence of laumontite (Ca-zeolite) at $~ 5740$ feet depth, as clear, sparry crystals coating fracture surfaces in large aperture open vugs, underlain by the $\mathrm{C} / \mathrm{S}$ phase corrensite. The occurrence of laumontite implies temperatures of $<200-220^{\circ} \mathrm{C}$. This is consistent with fluid inclusion data from calcite that document an early high-temperature inclusion group $\left(\mathrm{T} \approx 195^{\circ} \mathrm{C}\right)$ and a later low-temperature inclusion group $\left(\mathrm{T} \approx 160^{\circ} \mathrm{C}\right)$.

\section{C.5 CONCLUSIONS}

The clay analysis suggests that alteration temperatures in the lower volcanic section (and in the volcanogenic sediments) were at or above temperatures indicated by the thermal gradient measurements; that is, temperatures in the lower 2800 feet of the drill hole exceeded $75^{\circ} \mathrm{C}$, and ranged as high as $140^{\circ} \mathrm{C}$ at TD. The occurrence of corrensite (layered $\mathrm{C} / \mathrm{S}$ ) and laumontite at \pm 5740 feet (within and below the artesian fracture zone) implies somewhat higher temperatures associated with the geothermal fluids $140^{\circ} \mathrm{C}$ to $150^{\circ} \mathrm{C}$. As noted above, these temperatures are consistent with the fluid inclusion data from calcite, which document an early high-temperature inclusion group $\left(\mathrm{T} \approx 195^{\circ} \mathrm{C}\right)$ and a later low-temperature inclusion group $\left(\mathrm{T} \approx 160^{\circ} \mathrm{C}\right)$.

\section{C.6 REFERENCES}




\title{
Appendix D
}

\section{Sampling and Analysis of Geothermal Water}

\author{
Thomas Lachmar, Tom Wood, John Shervais
}

\section{D.1 WATER SAMPLING}

Six water samples were collected from the flowing test well at Mountain Home (Figure D.4-1) about 12 hours after the flow was encountered. The six samples consisted of: (1) $60 \mathrm{~mL}$ of filtered and acidified water for ICP and chloride analysis of major ions and metals; (2) $50 \mathrm{~mL}$ of filtered but unacidified water for deuterium $(\partial \mathrm{D})$ and oxygen $\left(\partial^{18} \mathrm{O}\right)$ analysis; (3) $125 \mathrm{~mL}$ of unfiltered and unacidified water for carbon-13 (13-C) analysis; (4) $1 \mathrm{~L}$ of unfiltered and unacidified water for tritium analysis; and (5) $250 \mathrm{~mL}$ of filtered and acidified water, and (6) $500 \mathrm{~mL}$ of unfiltered and unacidified water for duplicate analysis.

Sample (1) was analyzed by the Utah State University Analytical Laboratory for major ions and metals (Al, As, B, Ba, Ca, Cd, Cl, Co, Cr, Cu, Fe, K, Mg, Mn, Mo, Na, Ni, P, Pb, S, Se, Si, Sr, and Zn). The duplicate samples (5 and 6) were sent to Thermochem Labs (Santa Rosa, California) for elemental analysis, and were analyzed for trace metals and halides. The Thermochem samples were also analyzed for $\mathrm{D}$ and $\partial^{18} \mathrm{O}$. The separate $\partial \mathrm{D}$ and $\partial^{18} \mathrm{O}$ sample was analyzed by the Stable Isotope Ratio Facility for Environmental Research (SIRFER) at the University of Utah. The 13-C analysis (3) is being performed by Geochron Laboratories, a division of Krueger Enterprises, located in Billerica, MA, and the tritium sample (4) is being analyzed at Brigham Young University.

Temperature (the drillers reported that it was over $37^{\circ} \mathrm{C}$ after flowing for one hour), $\mathrm{pH}$, electrical conductivity, salinity, and alkalinity were measured in the field at the time of sampling (Table D.1-1). A Yellow Springs Instruments Model YSI 30 was used to measure temperature, conductivity, and salinity. An Orion Model 230A was used to measure pH. Alkalinity measurements were made within $20 \mathrm{mg} / \mathrm{L}$ using a Hach-Alkalinity Test Kit, Model AL-AP MG-L.

\section{D.2 RESULTS}

Chemical analysis of the geothermal water (Table D.2-1) shows that it is rich in sulfate relative to chloride and bicarbonate, and rich in sodium relative to calcium and magnesium (see Figure D.2-1). While the relatively high sodium is consistent with other geothermal water from the SRP, the high sulfate is a unique anomaly. The calculated TDS content of the water is relatively low at only $1,120 \mathrm{mg} / \mathrm{L}$, which is consistent with the low electrical conductivity $(870 \mu \mathrm{S})$. Deuterium and $18-\mathrm{O}$ levels are -88 and -3.2 per $\mathrm{ml}$, respectively. 
Table D.1-1. Compositions, measured and geothermometer temperatures of MHAFB well \#2.

\begin{tabular}{lllllllllllll}
\multicolumn{1}{c}{ Sample Name } & Temp C & $\mathrm{pH}$ & $\mathrm{Li}$ & $\mathrm{Na}$ & $\mathrm{K}$ & $\mathrm{Ca}$ & $\mathrm{Mg}$ & $\mathrm{SiO} 2$ & $\mathrm{~B}$ & $\mathrm{Cl}$ & $\mathrm{F}$ & $\mathrm{As}$ \\
\hline Mountain Home 2B USU & 140 & 9.59 & & 288 & 9.02 & 8.71 & 0.16 & 91.4 & 1.16 & 74.8 & & \\
Mountain Home 2B Thermochem & 140 & 9.75 & 0.12 & 313 & 9.11 & 9.64 & 0.02 & 101 & 1.44 & 76.7 & 0.573 & 0.0026 \\
\hline
\end{tabular}

\begin{tabular}{|c|c|c|c|c|c|c|c|c|c|c|c|}
\hline Sample Name & $\mathrm{Rb}$ & Cs & $\mathrm{Sr}$ & $\mathrm{Ba}$ & $\mathrm{Fe}$ & $\mathrm{Mn}$ & $\mathrm{SO} 4$ & $\mathrm{HCO} 3$ & $\mathrm{NH} 4$ & $\begin{array}{c}\text { del } \\
180 \\
\end{array}$ & del D \\
\hline Mountain Home 2B USU & & & 0.16 & 0.02 & 0.16 & 0.01 & 477 & 100 & & -3.2 & -88 \\
\hline Mountain Home 2B Thermochem & 0.05 & 0.05 & & & & & 508 & 103 & 1.68 & -3.086 & -87.61 \\
\hline
\end{tabular}

Table D.2-1. Chemical analysis of the geothermal water.

\begin{tabular}{|l|c|c|c|c|c|c|c|c|}
\hline \multicolumn{1}{|c|}{ Geothermometers } & \multicolumn{3}{|c|}{ Temperatures in degrees C } & & & & \\
\hline \multicolumn{1}{|c|}{ Sample Name } & $\begin{array}{c}\text { Quartz } \\
\text { cond }\end{array}$ & $\begin{array}{c}\text { Quartz } \\
\text { adiabatic }\end{array}$ & Na-K-Ca & $\begin{array}{c}\text { Na-K-Ca } \\
\text { Mg corr }\end{array}$ & $\begin{array}{c}\text { Na/K } \\
\text { Fournier }\end{array}$ & $\begin{array}{c}\text { Na/K } \\
\text { Truesdell }\end{array}$ & $\begin{array}{c}\text { Na/K } \\
\text { (Giggenbach) }\end{array}$ & $\begin{array}{c}\mathrm{K} / \mathrm{Mg} \\
\text { (Giggenbach) }\end{array}$ \\
\hline Mountain Home 2B USU & 132 & 129 & 132 & 132 & 134 & 89 & 154 & 119 \\
\hline $\begin{array}{l}\text { Mountain Home 2B } \\
\text { Thermochem }\end{array}$ & 138 & 133 & 136 & 136 & 130 & 84 & 150 & 154 \\
\hline
\end{tabular}




\section{D.3 DISCUSSION}

Preliminary geochemical results for geothermal water from the $\mathrm{MH}-2 \mathrm{~B}$ test well indicate that the water has a high $\mathrm{pH}(9.59)$ and is relatively high in sulfate. This result suggests that the water is at equilibrium with the altered basalt at the measured temperature. High-temperature sulfides (pyrite) have been observed on fracture faces in the lower sections of the Mountain Home core, and this probably is the source of the sulfate.

Calculated equilibrium temperatures vary from $\sim 132-138^{\circ} \mathrm{C}$ (quartz, Fournier and Potter, 1991), $\sim 134^{\circ} \mathrm{C}\left(\mathrm{Na} / \mathrm{K}\right.$, Fournier, 1981), $\sim 139^{\circ} \mathrm{C}\left(\mathrm{Na}-\mathrm{K}-\mathrm{Ca}\right.$, Fournier, 1981), to $\sim 154^{\circ} \mathrm{C}(\mathrm{Na} / \mathrm{K}$, Giggenbach, 1988 , 1991), and are consistent with the measured temperatures in the geothermal zone. This suggests that the system is at equilibrium, and that mixing with lower temperature shallow groundwater is negligible. The latter conclusion is supported by the heavy $\mathrm{D}$ and $\partial^{18} \mathrm{O}$ levels, which suggests that the water is old, is not meteoric, and/or has undergone significant fractionation.

Finally, the unique chemistry of the geothermal water will most likely be a boon to the development of this potential electric-grade resource. While the water is relatively high in sulfate and sodium, it is low in calcium, bicarbonate and chloride. This suggests that problems with encrustation and/or corrosion of piping will not be very serious. This supposition is supported by the relatively dilute nature of the water, as indicated by the low electrical conductivity $(870 \mu \mathrm{S})$ and low calculated TDS $(1,120 \mathrm{mg} / \mathrm{L})$.

\section{D.5 REFERENCES}

Fournier R.O., 1981, Application of Water Geochemistry to Geothermal Exploration and Reservoir Engineering in Geothermal Systems: Principles and Case Histories, Ryback and Muffler eds., John Wiley and Sons, NY, p. 109-143

Giggenbach, W.F., 1991, Chemical Techniques in Geothermal Exploration in UNITAR/UNDP Guidebook: Application of Geochemistry in Resources Development, p. 119-144.

Langmuir, D., 1971, The Geochemistry of Some Carbonate Groundwaters in Central Pennsylvania. Geochemica et Cosmochimica Acta, v. 35, p. 1023-1045. 


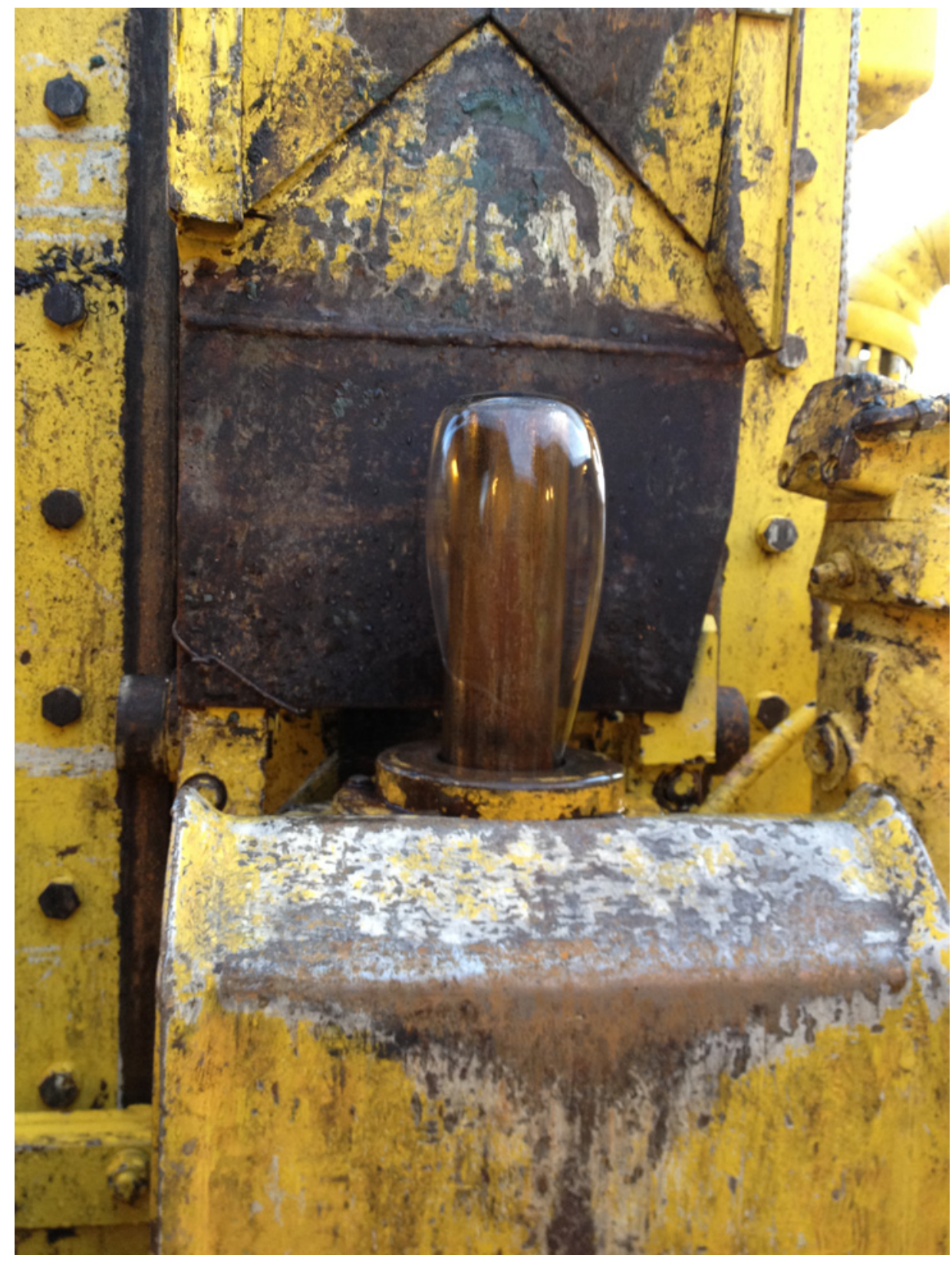

Figure D.4-1. Picture of flowing artesian water from a depth of $1750 \mathrm{~m}$ (5740 feet). 